\title{
Non-metallic Inclusions in Different Ferroalloys and Their Effect on the Steel Quality: A Review
}

\author{
YONG WANG, ANDREY KARASEV, JOO HYUN PARK, and PÄR G. JÖNSSON
}

\begin{abstract}
Ferroalloys have become increasingly important due to their indispensable role in steelmaking. In addition, the demand for improved steel qualities has increased considerably, which in turn highlights the quality of ferroalloys. This is due to the fact that the impurities in ferroalloys directly and significantly influence the quality of steel products. To gain a better understanding of the main trace elements and inclusions in ferroalloys (such as FeSi, FeMn, SiMn, FeTi, FeCr, $\mathrm{FeMo}, \mathrm{FeNb}, \mathrm{FeV}, \mathrm{FeB}$, some complex ferroalloys) and their behaviours in steel melt after the additions of these ferroalloys, information from a large number of previous results on this topic was extensively reviewed in this work. The applications of different ferroalloys and their production trends were discussed. In addition, the effects of some trace element impurities from ferroalloys on the inclusion characteristics in steel were also discussed. The possible harmful inclusions in different ferroalloys were identified. Overall, the results showed that the inclusions present in ferroalloys had the following influence on the final steel cleanliness: (1) $\mathrm{MnO}, \mathrm{MnS}$ and $\mathrm{MnO}-\mathrm{SiO}_{2}-\mathrm{MnS}$ inclusions from $\mathrm{FeMn}$ and $\mathrm{SiMn}$ alloys have a temporary influence on the steel quality; (2) the effect of large size $\mathrm{SiO}_{2}$ inclusions (up to $200 \mu \mathrm{m}$ ) in $\mathrm{FeSi}$ and FeMo alloys on the steel cleanliness is not fully understood. The effect of $\mathrm{Al}, \mathrm{Ca}$ contents should be considered before the addition of $\mathrm{FeSi}$ alloys. In addition, $\mathrm{Al}_{2} \mathrm{O}_{3}$ inclusions and relatively high $\mathrm{Al}$ content are commonly found in $\mathrm{FeTi}, \mathrm{FeNb}$ and $\mathrm{FeV}$ alloys due to their production process. This information should be paid more attention to when these ferroalloys are added to steel; (3) except for the existing inclusions in these alloys, the Ti-rich, Nb-rich, V-rich carbides and nitrides, which have important effects on the steel properties also should be studied further; and (4) specific alloys containing REM oxides, $\mathrm{Cr}-\mathrm{C}-\mathrm{N}, \mathrm{Cr}-\mathrm{Mn}-\mathrm{O}, \mathrm{Al}_{2} \mathrm{O}_{3}, \mathrm{Al}-\mathrm{Ti}-\mathrm{O}$, TiS and $\mathrm{Ti}(\mathrm{C}$, $\mathrm{N})$ have not been studied enough to enable a judgement on their influence on the steel cleanliness. Finally, some suggestions were given for further studies for the development of ferroalloy productions.
\end{abstract}

https://doi.org/10.1007/s11663-021-02259-7

(C) The Author(s) 2021

\section{INTRODUCTION}

FERROALLOYS consist of one or more alloying elements that are bound to iron, which are used to provide the desired chemical elements into molten steel. The most conventional elements used in ferroalloys are $\mathrm{Mn}, \mathrm{Si}, \mathrm{Cr}, \mathrm{Ca}, \mathrm{Al}, \mathrm{Mg}, \mathrm{Ti}, \mathrm{V}, \mathrm{W}, \mathrm{Mo}$, $\mathrm{Nb}, \mathrm{Ni}, \mathrm{B}$ and REM. ${ }^{[1]}$ These ferroalloys represent one of the most important raw materials for the steel

YONG WANG, ANDREY KARASEV and PÄR G. JÖNSSON is with the Department of Materials Science and Engineering, KTH Royal Institute of Technology, Brinellvägen 23, 10044 Stockholm, Sweden. Contact e-mail: yongwang@kth.se JOO HYUN PARK is with the Department of Materials Science and Engineering, KTH Royal Institute of Technology and also with the Department of Materials Science and Chemical Engineering, Hanyang University, Ansan 15588, Korea. Contact e-mail: basicity@hanyang.ac.kr

Manuscript submitted February 21, 2021; accepted June 11, 2021.

Article published online July 21, 2021. industry and about 85 to 90 pct of all ferroalloys being produced are used in steelmaking. ${ }^{[1]}$ More specifically, not a ton of steel is smelted without the use of ferroalloys. The main applications of ferroalloys can be summarized as follows: (i) deoxidizers such as FeSi, FeMn, SiMn and FeAl, (ii) alloying agents to improve the mechanical properties and functional characteristics of steel products such as $\mathrm{FeCr}$, FeMo, FeW, FeTi, FeB, and (iii) reducing agent such as FeSi which can be used as a reducing agent for the production of $\mathrm{FeMo}, \mathrm{FeV}$ and other alloys. ${ }^{[2]}$

The history of ferroalloys is relatively short compared to the development of bronze or iron. Ancient iron products were made of nearly pure iron containing only carbon as an alloying element. At the end of the 18th and early 19th century, elements such as nickel, manganese, chromium, molybdenum, silicon, etc. were discovered ${ }^{[3]}$ At that time, chemical reactions such as combustion/oxidation and reduction were better understood. This made it possible to recognize essential events 
of contemporary iron and steelmaking processes and to start developing new processes. Since then, the mechanisms on how alloying elements influenced the steel microstructures and properties gradually began to be studied ${ }^{[3]}$ Metallurgists started to consider the addition of alloying elements to steel in the form of ferroalloys. This was also driven by economical advantages, since it is easier and more economical to produce ferroalloys compared to making pure elements $(\mathrm{Mn}, \mathrm{Cr}, \mathrm{Si}, \mathrm{Ti}, \mathrm{V}$, $\mathrm{W}, \ldots$ ) to be added to steel. Gradually, a great variety of ferroalloys for general use or designed for specific steel grades have become available.

A high-Mn FeMn alloy was started to be produced in a blast furnace in 1877 and thereafter other kinds of ferroalloys ( $\mathrm{FeSi}, \mathrm{FeTi}$ and $\mathrm{FeV}$ ) were also produced in a blast furnace. ${ }^{[3]}$ However, it was not possible to produce ferroalloys with elements that have a higher affinity to oxygen or with low carbon contents when using a blast furnace. Furthermore, it was uneconomical to produce alloys with high alloy contents in blast furnaces due to the insufficiently high temperature and other production factors. Therefore, this led to the development of ferroalloys which were manufactured using electric furnaces at the beginning of the 20th century. Since then ferroalloys have been produced exclusively in electric furnaces.

The applications of ferroalloys in steelmaking may be done by using small additions to ordinary mild steels and high strength low-alloyed steels or by using larger additions when producing high-alloy steels. In recent years, increasing demands for special quality steel materials have called for efforts to decrease the impurities to extra-low concentrations. The material properties of steels are dependent not only on the process but also on the quality of the primary materials, including ferroalloys. As a matter of fact, some special steels can only be produced with specific properties by adding selected refined ferroalloys. It is quite apparent that the market demands imposed on the steelmaker will be reflected on the ferroalloy producer, because very stringent quality requirements are needed.

Nowadays, steel cleanliness largely depends on the alloying process as it proceeds the solidification of steel, since ladle metallurgy is the last step before the casting process. The non-metallic inclusions (NMIs), which are observed after the addition of ferroalloys, are frequently present as complex compounds with variable chemical compositions. Here, the impurities present in ferroalloys are one of the major contributions to the formation of these complex inclusions. In the primary alloying step during ladle refining, the additions of ferroalloys have no big influence on the steel quality because the ordinary deoxidation is finished, and the inclusions caused by ferroalloy additions have enough time to be transformed and to be separated from the steel. ${ }^{[4]}$ More critical additions are related to the final corrections made at a late stage of ladle refining just before casting or additions directly in a tundish or a mold as well as in the ingot during casting. ${ }^{[3,5]}$ Due to the late addition in these processes, there is limited time to eliminate the influence of ferroalloy additions on the steel cleanliness. Therefore, ferroalloys with an unknown amount of impurities can cause an uncontrollable increased number of NMIs in steels, which tends to decrease the quality of the final steel products. Thus, the avoidance of late ferroalloy additions is especially important in the production of high-quality alloy steels such as stainless steels, bearing steels and tool steels. In other words, high-purity ferroalloys are needed to meet the composition requirements without increasing the refining time. Therefore, the impurities in these types of ferroalloys and the effect of impurities in ferroalloys on the steel cleanliness have been a subject of special attention in previous research. ${ }^{[5-8]}$

Several books and papers have been published and numerous conferences have been held focusing on ferroalloys. However, these publications ${ }^{[1,2,9-16]}$ have in general been more concerned about the production theories and technologies to produce ferroalloys, but few studies have focused on steel cleanliness related to ferroalloy additions. However, due to the increasing demands for improved qualities of steel, the interest for this topic increased during the last decade. Thus, some researchers ${ }^{[17-22]}$ have reported results concerning impurities in ferroalloys. However, there is an absence of an overview of all results obtained during the last 20 years. Therefore, a need has been identified to collect and summarize the data on a broader perspective view. This work aims to provide a unified, comprehensive and combined overview of impurities present in different ferroalloys as well as how these impurities can influence the steel cleanliness. It is the authors' ambition that the results can be used for the determination of the requirements for ferroalloys and how to optimize the technological parameters (such as time and intensity of melt stirring, holding time before steel casting, etc.) during the production of high-quality alloyed steels.

\section{DIFFERENT FERROALLOYS}

\section{A. Classification of Ferroalloys and Their Applications in Steelmaking}

Various ferroalloys are used in the steelmaking process to improve the properties of steel. According to the added ferroalloy amount during steel production, they are usually classified into three groups: major ferroalloys (produced in large quantities, such as $\mathrm{FeSi}$, $\mathrm{FeMn}, \mathrm{FeCr}, \mathrm{SiMn}$ ) and minor ferroalloys (produced in smaller quantities but of high importance, such as $\mathrm{FeW}$, FeMo, FeNi) and micro-alloys (FeV, $\mathrm{FeNb}, \mathrm{FeB}$ ). Based on the carbon content in ferroalloys, they are also classified into high-carbon (HC), medium-carbon (MC), low-carbon (LC) ferroalloys. Besides these classifications, the easiest way is to classify them based on their main elemental compositions.

It is well known that the compositions of the added ferroalloys directly affect the compositions of steels. The most important factor for assessing the quality of a ferroalloy is the content of its chief alloy constituents. Typical compositions of some commonly used ferroalloys in steelmaking are shown in Table I. The number inside the () means the composition of the former 
Table I. The Classification of Different Ferroalloys ${ }^{[9]}$

\begin{tabular}{|c|c|c|c|c|c|c|c|c|}
\hline & $\mathrm{Si}$ & $\mathrm{Al}$ & $\mathrm{C}$ & $\mathrm{Mn}$ & $\mathrm{Cr}$ & V & B & $\mathrm{Ti}$ \\
\hline $\operatorname{FeSi}(10,15,20)$ & $8-30$ & $<1.5$ & $1-2$ & $1-3$ & 0.8 & - & - & - \\
\hline $\operatorname{FeSi}(45,50,65)$ & $41-68$ & $<2$ & 0.2 & $0.4-1$ & 0.5 & - & - & - \\
\hline $\operatorname{FeSi} 75 \mathrm{Al}(1,2,3)$ & $72-80$ & $<3$ & 0.15 & 0.5 & 0.3 & - & - & - \\
\hline $\operatorname{FeSi90Al}(1,2)$ & $87-95$ & $<3$ & 0.15 & 0.5 & 0.2 & - & - & - \\
\hline $\operatorname{FeSi}(12,17,22,25) \mathrm{Mn}$ & $10-35$ & - & $0.5-3.5$ & $>60$ & - & - & - & - \\
\hline $\operatorname{LCFeMn}(85,90)$ & $1-2$ & - & $0.2-0.5$ & $85-95$ & - & - & - & - \\
\hline $\operatorname{MCFeMn}(75,85,88)$ & $1-3$ & - & $1-2$ & $75-95$ & - & - & - & - \\
\hline $\operatorname{HCFeMn}(70,75,78)$ & $1-6$ & - & $6-7.5$ & $70-82$ & - & - & - & - \\
\hline $\mathrm{LC}(0.2,0.5,1,2) \mathrm{FeCr}$ & $<1.5$ & - & $0.01-0.25$ & - & $45-95$ & - & - & - \\
\hline $\mathrm{MC}(10,20,40) \mathrm{FeCr}$ & $<1.5$ & - & $0.5-4$ & - & $45-95$ & - & - & - \\
\hline $\mathrm{HCFeCr}(50,70,90)$ & $<1.5$ & - & $4-10$ & - & $50-90$ & - & - & - \\
\hline $\operatorname{FeCrSi}(13,20,26,33,40)$ & $10-45$ & - & $0.2-6$ & - & $35-55$ & - & - & - \\
\hline FeTi20 & $5-30$ & $5-25$ & 1 & - & - & - & - & $20-30$ \\
\hline FeTi30 & 4 & 8 & 0.12 & - & - & 0.8 & - & $28-37$ \\
\hline FeTi35Si(1, 5, 7, 8) & $1-8$ & $8-14$ & 0.2 & - & - & $0.4-1$ & - & $28-40$ \\
\hline FeTi75Si $(0.5,0.8)$ & $0.5-0.8$ & $4-5$ & 0.3 & - & - & $0.6-3$ & - & $65-75$ \\
\hline FeV40 & 2 & 0.5 & $0.5-1$ & $2-6$ & - & $35-48$ & - & - \\
\hline FeV50 & 2 & $0.2-2.5$ & $0.3-0.75$ & $0.2-5$ & - & $48-60$ & - & - \\
\hline FeV75 & $0.8-1$ & $2-2.5$ & $0.1-0.15$ & $0.4-0.6$ & - & $70-85$ & - & - \\
\hline $\operatorname{FeB}(6,10,17,20)$ & $2-12$ & $0.5-12$ & $0.05-4$ & - & - & - & $6-20$ & - \\
\hline FeBAl & 10 & 10 & - & - & - & - & 6 & - \\
\hline FeSiBAl & 15 & 15 & - & - & - & - & 10 & - \\
\hline FeSi-REM $(5,10,15,20,30)$ & $2-8$ & $3-15$ & - & - & - & - & - & - \\
\hline $\operatorname{FeMn}(45,55,65) \mathrm{Al}$ & $<2.5$ & $12-16$ & - & $40-80$ & - & - & - & - \\
\hline $\mathrm{FeMnCr}$ & $<1.6$ & - & $<0.05$ & $16-44$ & $31-54$ & - & - & - \\
\hline FeMnSiCr & $20-40$ & - & $<0.05$ & $15-35$ & $20-30$ & - & - & - \\
\hline $\mathrm{FeCrAl}$ & $0.5-1$ & $18-22$ & - & - & $48-52$ & - & - & - \\
\hline FeMnAlSi & $10-15$ & $10-14$ & $1-2$ & $22-24$ & - & - & - & - \\
\hline
\end{tabular}

element for different grade alloy and the balanced element in these ferroalloys is Fe. The characteristics and the common uses of these alloys are briefly described below.

The main types of silicon additions in steelmaking are made using ferrosilicon ( $\mathrm{FeSi}$ ) and silicon-manganese (SiMn) alloys, but some other silicon ferroalloys are also used. ${ }^{[23,24]} \mathrm{FeSi}$ alloys are widely used to increase the strength and wear resistance, elasticity (spring steels), scale resistance (heat-resistant steels) as well as to decrease the electrical conductivity and magnetostriction (electrical steels). ${ }^{[25]}$ Moreover, the addition of Si in the steel melt reduces the oxidation tendency of valuable elements such as $\mathrm{Cr}$ and Mo during stainless steel production. They can also be used to increase the tensile yield and annealing resistance in steels. ${ }^{[26]}$

Deoxidation and alloying of steel and cast iron are the largest application of FeSi alloys. SiMn alloys are more effective deoxidizers compared to when using individual additions of FeSi and FeMn. Deoxidation with SiMn alloys results in cleaner steel as the liquid manganese silicate which is formed tend to coalescence into larger aggregates. These, in turn, may more easily be separated from steel. Standard SiMn alloys are used in most Siand Mn-containing steels where the combination of carbon, manganese, silicon, and trace elements fits the final steel composition analysis in an economical way. ${ }^{[27]}$

FeMn alloys are commonly used as deoxidizers, for minimizing the harmful effect of sulfur and alloys to increase the strength and toughness of steel. The $\mathrm{HCFeMn} \mathrm{(2} \mathrm{to} 8$ mass pct $\mathrm{C}$ ) is the traditional form of an Mn addition, but it is limited to be used for unalloyed and low-alloyed carbon steels. The MCFeMn ( 0.7 to 2 mass pet $\mathrm{C})$ and $\mathrm{LCFeMn}(<0.7$ mass pet $\mathrm{C})$ alloys are used where the carbon content cannot be reduced after the addition of the ferroalloy.

$\mathrm{FeCr}$ alloys are generally used in stainless steels to increase the resistance to wear, heat and corrosion as well as to improve the creep and impact properties. Chromium is an essential alloying element for the production of special alloyed steels, on account of the special properties of chromium imparts to these materials. More than 90 pct of the $\mathrm{HCFeCr}$ (4 to 10 mass pct C) alloys are used for the production of stainless steels. ${ }^{[28]}$ This is due to the ability of chromium to provide a protective layer of chromium oxide when its content is higher than 11 mass pct in steel. ${ }^{[23]}$ Moreover, $\mathrm{LCFeCr}(<0.25$ mass pct $\mathrm{C})$ alloys are mostly used to produce corrosion-resistant chromium-nickel and chromium steels. They are also used when it is desired to add chromium to low-carbon steels.

FeTi alloys are usually used in the productions of interstitial-free, stainless, corrosion-resistant steels and high-strength low-alloy steels. ${ }^{[1]}$ Due to the high affinity of titanium to oxygen, carbon and nitrogen, FeTi alloys are utilized in steelmaking to bind these elements and to decrease their harmful effects on the final steel properties. They are commonly used for alloying, deoxidation and degassing in the metallurgy of high-quality steels and alloys. FeTiSi alloys are also widely used to allow the simultaneous addition of silicon and titanium to steel. 
$\mathrm{FeV}$ alloys are used in steelmaking to refine grains as well as to improve the hardness, ductility, thermostability and wear resistance of steel. Vanadium is a strong carbide former, which causes carbide particles to form in the steel. It is essential for the production of carbon steels and many alloy steels. About 85 pct of all vanadium is used in the steel industry to produce high-strength low-alloy (HSLA) steels as well as tool and die steels. ${ }^{[29]}$

FeB alloys are widely used for steelmaking, not only for high-strength and wear-resistant steels but also in the production of relatively new pipe steels of high strengths and martensitic steels to be used in the automotive industry. ${ }^{[30-32]}$ Boron is a typical microalloying element, which even in small additions in steel have a great influence on the mechanical properties. ${ }^{[33]}$ In addition, FeB alloys are used to avoid the interstitial nitrogen effect and to improve the steel's formability.

Metallurgical applications account for about one-third of the worldwide consumption of rare-earth metals (REM). The main function of REM in steels is to control the shape of non-metallic inclusions (sulfides, silicates, oxides) which remain in killed and desulfurized steels. ${ }^{[34]}$ The presence of REM in steel decreases the anisotropy of properties, due to the tendency to form hard globular inclusions. In addition, REM elements contribute to preserving a high level of strength characteristics as well as to maintain an elevated ductility and impact toughness. ${ }^{[35]}$

Complex ferroalloys contain more than two alloying elements, which are used in special steel manufacturing for alloying and refining (oxygen, sulfur, etc.) purposes. The apparent advantages of complex alloys are the more controlled formation of inclusions in steels. One example is the use of FeSiMnAl alloy, which allows for a more efficient deoxidation compared to when FeSi, FeMn, and Al are added separately. ${ }^{[36]}$ In addition, complex ferroalloys containing boron have clear beneficial characteristics (melting point, density, melting time of the ferroalloy in liquid steel, etc.) compared to those of ferroboron. ${ }^{[37]}$

\section{B. World Production of Ferroalloys}

The progress and data of ferroalloys production are frequently compared to data from the steel industry, which is a closely related sector. Thus, the state of the steel industry determines the trends in ferroalloy production as steelmaking is the basic consumer of ferroalloys. The production of steels in the world has increased rapidly during the last two decades, and the production of major ferroalloys follows roughly the growth of steel production. ${ }^{[3]}$ Take stainless steel as an example, ${ }^{[1]}$ where the annual growth rate has been more than 5 pct. This, in turn, will lead to a corresponding growth rate for the use of $\mathrm{FeCr}$, FeMo and $\mathrm{FeNi}$ alloys. Considering the other bulk ferroalloys such as FeMn, $\mathrm{FeSi}$, and SiMn, where the demand is bound more to low-alloyed carbon steels, the growth will continue to take place in countries especially with growing economies.
Different grades of ferroalloys have been developed to fulfil the varying requirements of the steel industry. A survey of the world market is necessary to understand the situation with respect to the production of ferroalloys better. From a global perspective, the leading ferroalloy-producing countries in 2018 were, in decreasing order of production: China (31.2 Mt), South Africa (4.82 Mt), Kazakhstan (1.97 Mt), India (1.92 Mt), Russia $(1.73 \mathrm{Mt})$, and Ukraine $(1.34 \mathrm{Mt}),{ }^{[38]}$ as shown in Figure 1. The total production amount in these six countries accounts for almost 90 pet of the world ferroalloy production.

The ferroalloys that depend most heavily on the role of business activities in the steelmaking process are those based on silicon, manganese, and chromium. These three types of alloys are widely applied in steelmaking. The production structure in the world of ferroalloys is shown in Figure 2. The world leader based on the production volume is manganese alloys accounting for 41 pet of the total production. This is followed by silicon and chrome alloys accounting for 26 and 24 pct, respectively. In addition, the main ferroalloys being produced are SiMn, FeCr, FeSi and FeMn. The word productions of these four types of ferroalloys from 2008 to 2018 are presented in Figure $3 .^{[38,39]}$ It can be seen that the production of SiMn is the largest and it increased from 7.4 Mt in 2008 to $12.6 \mathrm{Mt}$ in 2018. SiMn is mainly used in the production of electrical steels. The production of $\mathrm{FeCr}$ also increased during this period, although some fluctuations existed. This increase is a reflection of the increasing demand for chromium-bearing stainless steels. As for FeSi, it witnessed a slight increase from 2008 to 2013, after which it decreased. The production for FeMn did not show an obvious increase, but rather some small fluctuating changes during this period. Overall, a SiMn alloy is a suitable addition for deoxidation, whereas the FeSi and FeMn alloys are mainly used for alloying purposes.

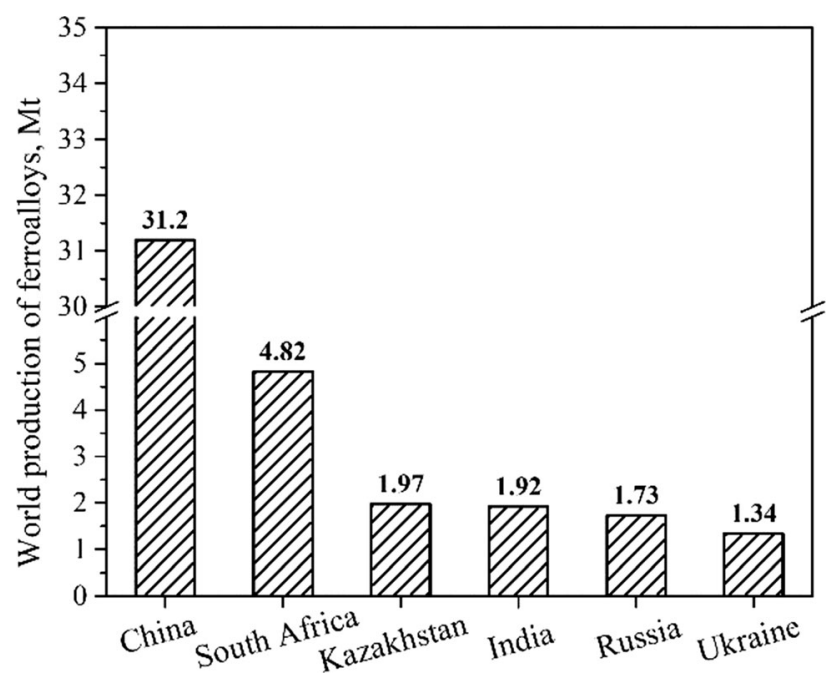

Fig. 1-Main producers of ferroalloys in $2018^{[38]}$ 


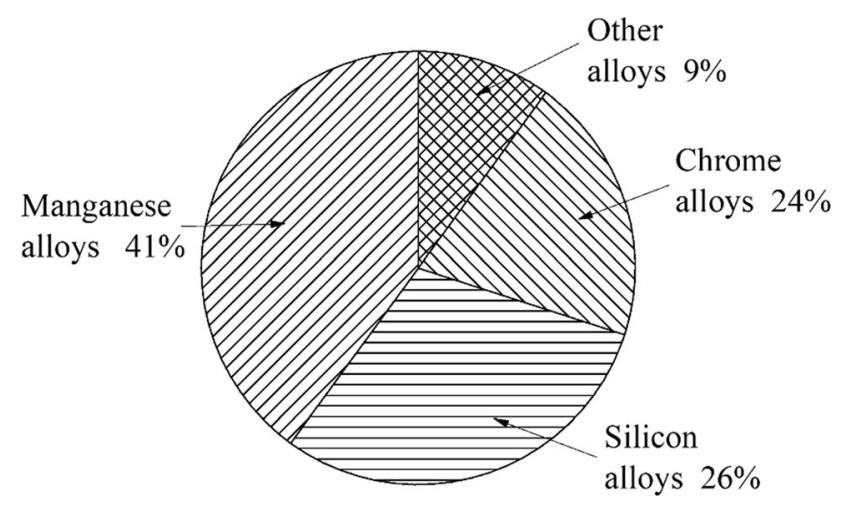

Fig. 2-World ferroalloy production structure ${ }^{[38]}$

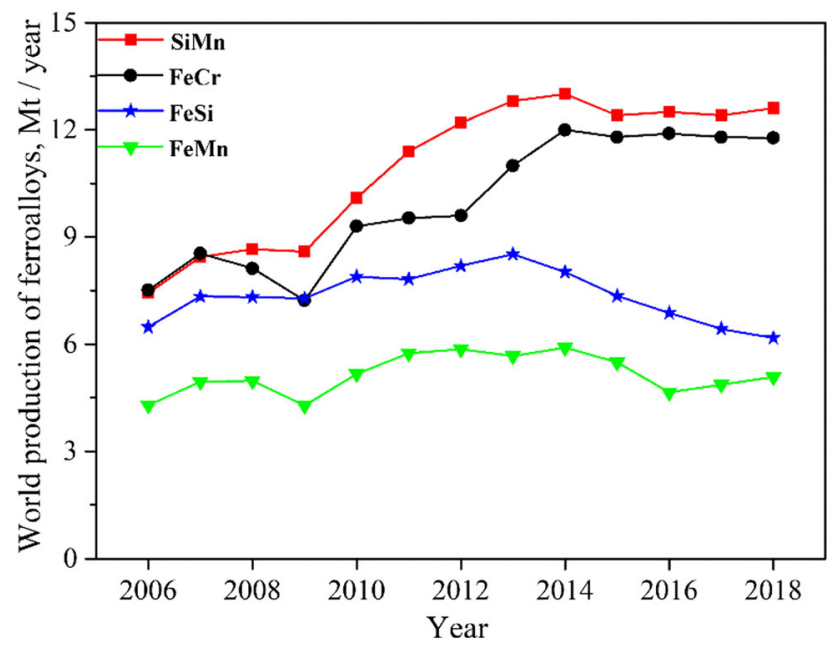

Fig. 3-World production of SiMn, FeCr, FeSi and FeMn alloys ${ }^{[38,39]}$

The largest ferroalloy producers are nations with large reserves of raw materials. Figure 4 shows the production of different ferroalloys in the top four producing countries. ${ }^{[38,39]}$ In the case of SiMn alloys, it can be seen that the production increased from 2008 to 2013 and that it thereafter remained almost the same levels for both China and India. Other important SiMn producers are Ukraine and Norway, for which the production trend showed no significant change during the same period. When it comes to $\mathrm{FeCr}$ production, China witnessed a significant production increase from 2008 to 2014 and then a slight increase until 2018. The production in South Africa was higher than that in China before the year of 2012 and it slightly increased afterwards. However, the production in Kazakhstan and India remained almost stable at 1.2 and $0.9 \mathrm{Mt}$, respectively. The FeSi consumption is driven by cast iron and steel production, where silicon alloys are used as deoxidizers and alloying agents. As for the production of FeSi alloys, the undisputed leader was China, which produced over $4 \mathrm{Mt}$ during the whole period from 2008 to 2018. Specifically, the production increased from 2008 to 2013 and then showed an obvious decrease up to 2018. In addition, the production levels in Russia, Norway and Ukraine were almost stable during the whole period. The leading FeMn producing countries were China, India, Japan and Norway. Similar to the case of the FeSi production, China showed a maximum peak in 2013 and thereafter the production decreased to about $2 \mathrm{Mt}$ in 2018. Overall, it can be seen that ferroalloy production represents a large industry, which is geographically scattered around the world.

\section{IMPURITIES IN FERROALLOYS AND BEHAVIOUR OF NMI FROM FERROALLOYS IN THE STEEL MELT}

The increasing demands for special steels with stringent quality requirements particularly with respect to a restricted chemical composition and cleanliness, results in the fact that the cleanliness of ferroalloys is becoming increasingly more significant in steelmaking. Ferroalloys have a high content of the major alloying component, while the rest being mostly iron and more or less "residues" of reductants used in the ferroalloy production. Moreover, the effect of added ferroalloys on steel cleanliness depends on the contents of impurities and inclusions present in the ferroalloys.

The contribution of the ferroalloy cost to the total cost of steelmaking depends on the type of steel grades being produced. There is no doubt that the ferroalloy represents an expensive input material to steel products, especially in the production of high-alloyed steels. Therefore, a lot of efforts have been made to reach a balance between maximizing the ferroalloy recovery and reducing the cost of steelmaking using low-quality ferroalloys. Here, the addition practice is one of the important factors affecting the ferroalloy yield. Various methods have been developed for the addition of ferroalloys, i.e., lump dropping, wire feeding, and powder additions. The dropping method is relatively easy and widely used and it is usually made during tapping or ladle refining. Wire feeding is usually used for the addition of expensive elements or elements with a low boiling point to ensure a high yield. Moreover, additions of powders by using a submerged lance are used to avoid reactions between the alloy and slag.

Apart from the addition method, the addition sequence of ferroalloys is also important in the steelmaking process. For instance, the weaker deoxidizers are usually added before the stronger ones and high-carbon ferroalloys are added at an early stage of steelmaking. The alloying elements which have a high affinity to oxygen are usually added in a deoxidized steel. In many cases, the behaviour of inclusions in steel melt depends on the sequence of alloy addition. ${ }^{[40]}$ One production route of ultra-low carbon steel can be taken as an example ${ }^{[41]}$ at which various ferroalloys can be added into the steel during different stages of ladle treatment after tapping from the converter, as shown in Figure 5. In this process, $\mathrm{FeP}$ is usually added before deoxidation which is performed at stages 1 and 3 of the ladle refining. However, FeSi75 and FeTi alloys are only added after complete deoxidation has been performed at stage 4 of the ladle refining to reach a maximum alloy yield. 


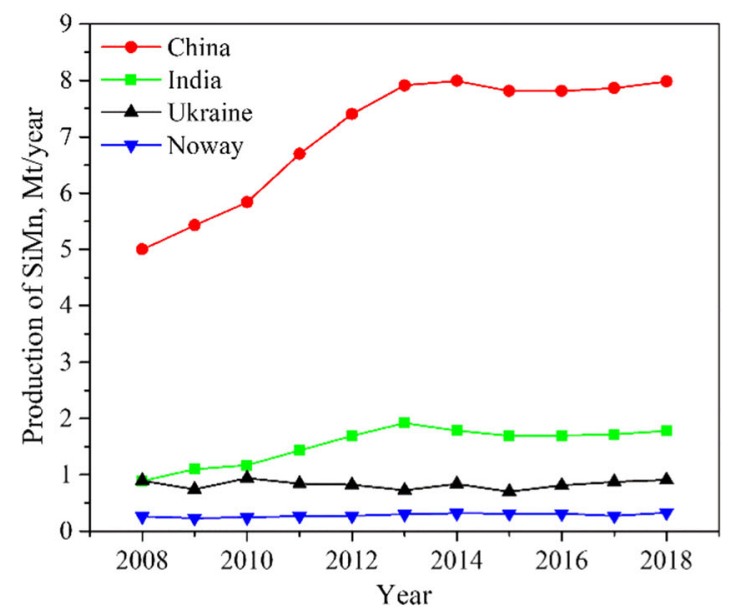

(a)

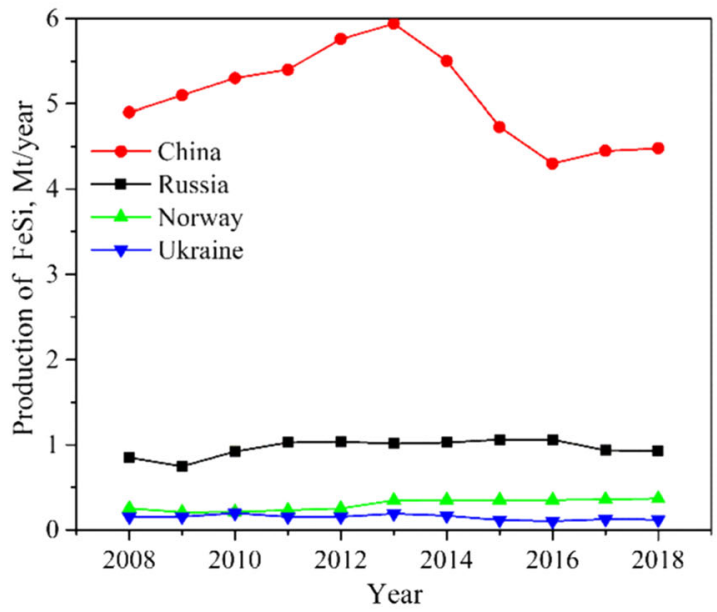

(c)

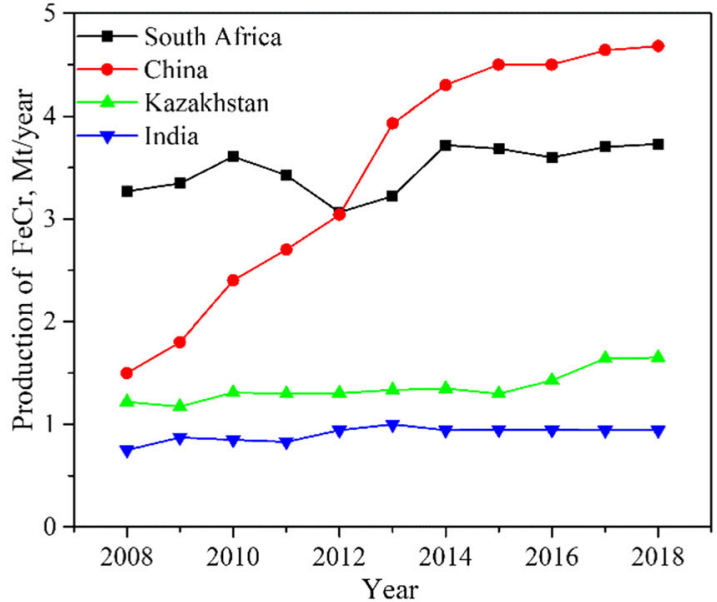

(b)

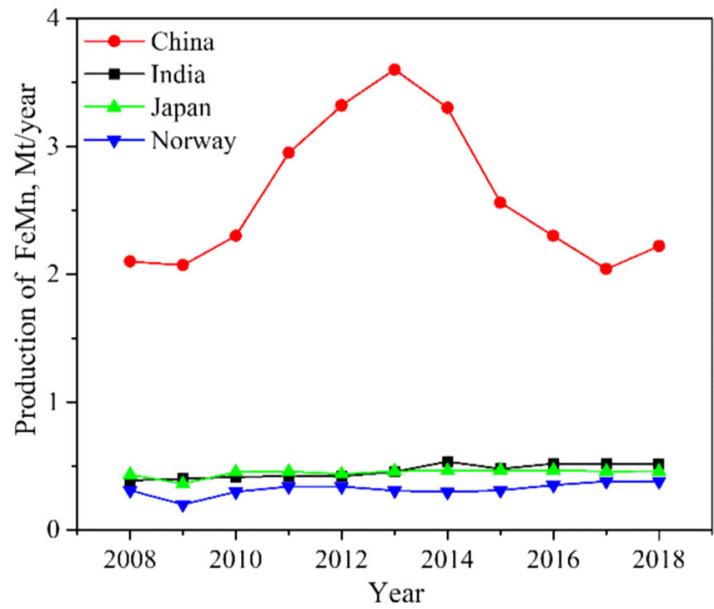

(d)

Fig. 4-Production of four types of ferroalloys: (a) SiMn, (b) FeCr, (c) FeSi, (d) FeMn during 2008 to 2018 $8^{[38,39]}$

The physical properties of ferroalloys have a direct influence on their melting and dissolution behaviour, which will be considered in a separate paper. The influence of ferroalloys on the final steel quality was summarized by Wang et al., ${ }^{[22]}$ as shown in Figure 6. It is reasonable to assume that the inclusions in ferroalloys can be inherited as inclusions in the steel. However, there is an absence of a summary on the influence of ferroalloys on the steel cleanliness. Therefore, this is discussed in detail in this section of the paper.

\section{A. Element Impurities in Different Ferroalloys}

It is apparent that the impurities present in ferroalloys can have a marked effect on the quality of steels. Specifically, the harmful effects of the impurities depend on the extent of the impurities in the ferroalloys and the requirements of the steel specifications. Uncontrolled impurities in ferroalloys cause downgradings of steels and add to the specific cost of production of ferroalloys. Therefore, all these information related to ferroalloys should be known before their introduction to liquid steel. Typical impurities in ferroalloys contain $\mathrm{H}, \mathrm{N}, \mathrm{O}$, $\mathrm{S}$ and $\mathrm{P}$ as well as other trace elemental impurities such as $\mathrm{Al}, \mathrm{Ca}, \mathrm{Mg}, \mathrm{Ti}, \mathrm{V}$, etc. Overall, this depends on the type of ferroalloy and the type of inclusions present in that particular ferroalloy.

\section{Impurities of gaseous $H, N, O, S$ and $P$}

It is well known that hydrogen $(\mathrm{H})$ lowers the tensile ductility in many materials such as in austenitic stainless steels and aluminium alloys. One of the origins of $\mathrm{H}$ is the added ferroalloys. The same reasoning applies to nitrogen $(\mathrm{N})$. Therefore, several special steel grades have an upper limit on the $\mathrm{H}$ and $\mathrm{N}$ contents. Thus, their levels in ferroalloys have also become important. For instance, chrome-moly-based creep-resistant steels require an $\mathrm{N}$ limit of $70 \mathrm{ppm}$, so that proper a low nitrogen $\mathrm{FeCr}$ should be selected. ${ }^{[2,43]}$ In the stainless steel field, $\mathrm{N}$ is one element that causes a great deal of concern. Therefore, FeTi alloys containing a low N content can assist in reducing the $\mathrm{N}$ content in steels. ${ }^{[44]}$

Moreover, it is generally known that the oxygen $(\mathrm{O})$ and sulfur (S) contents in ferroalloys have a direct effect on steel cleanliness. A transfer degree of $\mathrm{O}$ from the ferroalloys to the steel melt is known to be up to 95 pct. ${ }^{[4]}$ In addition, the phosphorus (P) content should be kept low, since it has a tendency to migrate to the 
grain boundaries, which makes the steel brittle. The contents of $\mathrm{O}, \mathrm{S}$ and $\mathrm{P}$ present in various ferroalloys are given in Table II.

Wijk and Brabie ${ }^{[6]}$ reported that the $\mathrm{O}$ contents varied from 160 to $3600 \mathrm{ppm}$ in different grades of FeSi alloys. The presence of such a big difference was due to the different production processes and raw materials being used. In some ferroalloys, the $\mathrm{O}$ content is quite high, up to thousands of ppm (such as about $6500 \mathrm{ppm}$ in FeTi, 6000 ppm in FeMo). Sjökvist et al. ${ }^{[7]}$ showed that the $\mathrm{O}$ content could be as high as 1.1 mass pet in FeMn alloys. So what effect can these oxygen contents have on steel?

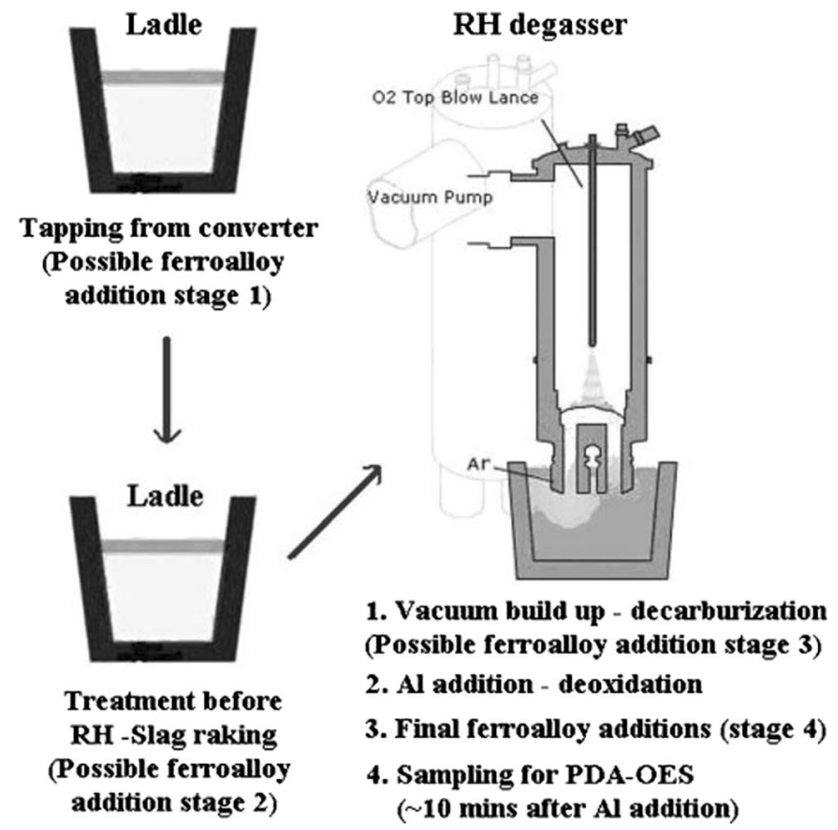

Fig. 5-Possible stages for ferroalloy additions during the ladle treatment process. Reprinted with permission from Ref. [41].
According to the simple calculation, for the aimed $\mathrm{Ti}$ content of $500 \mathrm{ppm}$ in interstitial-free (IF) steels, the required amount of FeTi35 was $1.9 \mathrm{~kg}$ per tonne of steel. This resulted in an increased $\mathrm{O}$ content of $12 \mathrm{ppm}$ in steel. ${ }^{[21]}$ Meanwhile, the $\mathrm{O}$ content can reflect the oxide inclusion content in different ferroalloy grades. Typically, the higher the $\mathrm{O}$ content the more oxide inclusions, which will increase the possibility of introducing more inclusions to the steel.

In addition to the $\mathrm{O}$ content, $\mathrm{S}$ and $\mathrm{P}$ in minor quantities can also impair the quality of steel because the allowable limits have become quite low in high-quality steels. As can be seen from Table II, the S content in most ferroalloys is less than 500 ppm, except for the FeMo and FeV alloys. It is necessary to take the $\mathrm{S}$ content in the ferroalloy into account for the steel grades with extra-low sulfur contents (e.g., $\mathrm{S}<5$ ppm). However, the actual behaviour of $\mathrm{S}$ from added ferroalloys in steel melt on the final steel properties has rarely been studied. In addition, a wide range of $\mathrm{P}$ content exists in ferroalloys, where the lowest can reach $10 \mathrm{ppm}$ and the highest can reach values up to $3500 \mathrm{ppm} .{ }^{[23]}$ The $\mathrm{P}$ content can hardly be corrected in secondary steelmaking, e.g., the removal of $\mathrm{P}$ is practically impossible especially in stainless steels. Consequently, the $\mathrm{P}$ content should be strictly controlled from the origins. For instance, a high $\mathrm{P}$ content in a FeMn alloy often results in downgrading in manganese-bearing restricted phosphorous steels. ${ }^{[42]}$ It should also be noted that the $\mathrm{P}$ content must be adjusted from the ore treatment (such as through mineral beneficiation) as there are no commercially established technologies available to remove $\mathrm{P}$ from the molten ferroalloys. ${ }^{[2]}$ With the trend towards the production of cleaner steels, the foremost consideration is higher-grade ferroalloys with lower contaminations of sulphur, phosphorous, nitrogen, oxygen and hydrogen.

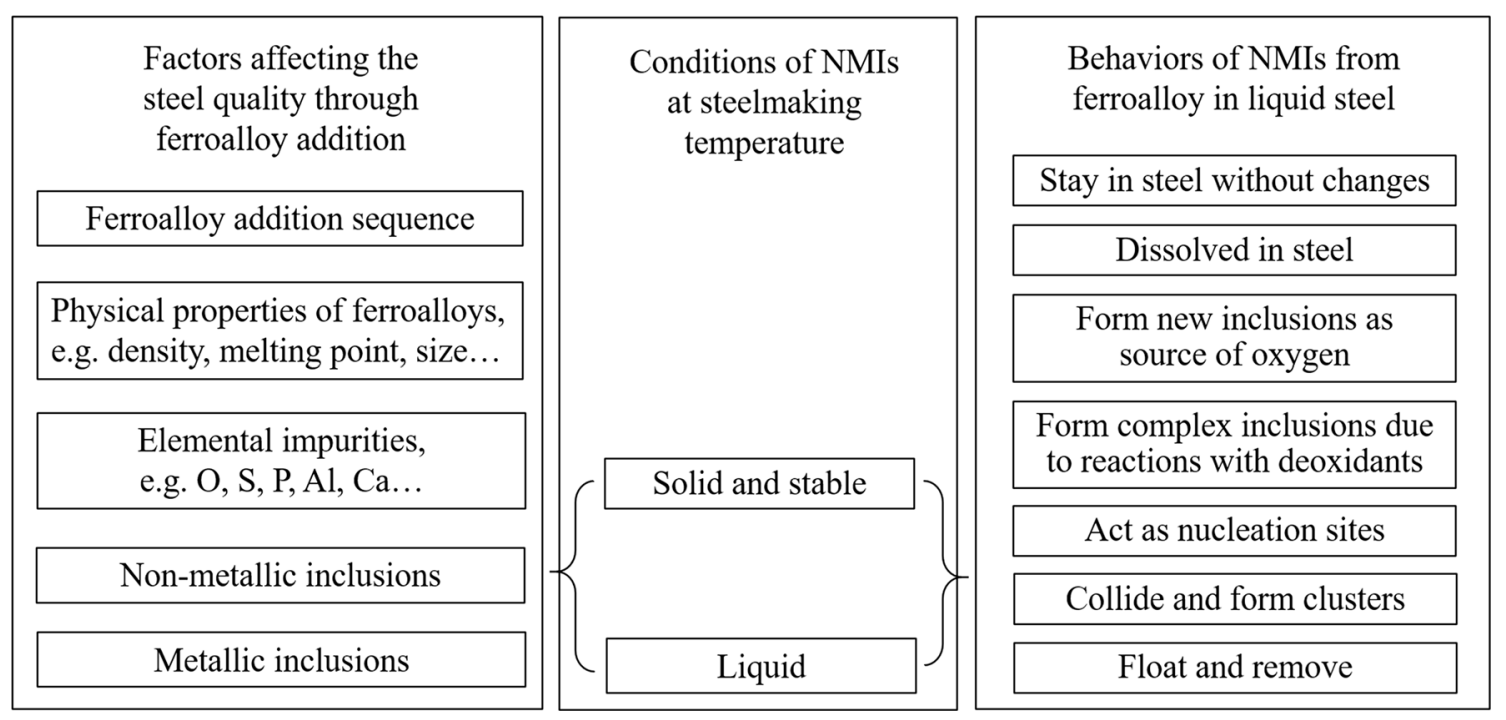

Fig. 6-The possible effect of ferroalloy additions on the quality of the steel cleanliness. Reprinted from Ref. [22], under the terms of the Creative Commons CC BY license. 
Table II. Contents of O, S and P and Trace Elements in Different Ferroalloys

\begin{tabular}{|c|c|c|c|c|c|}
\hline Type & $\mathrm{O}(\mathrm{Ppm})$ & $\mathrm{S}(\mathrm{Ppm})$ & $\mathrm{P}(\mathrm{Ppm})$ & Trace Elements (Mass Pct) & Ref. \\
\hline FeSi65 & 1700 & 10 & 10 & $2-3.5 \mathrm{Al}$ & 45 \\
\hline FeSi65 & - & $20-61$ & $150-250$ & $0.98-1.06 \mathrm{Al}, 0.22-0.31 \mathrm{Ca}, 0.2-0.39 \mathrm{Mg}$ & 46 \\
\hline FeSi72 & 1270 & 150 & 130 & $0.18 \mathrm{Al}, 0.007 \mathrm{Ca}$ & 47 \\
\hline FeSi72 & 780 & 120 & 350 & $0.05 \mathrm{Al}, 0.011 \mathrm{Ca}$ & 47 \\
\hline FeSi72 & 450 & 170 & 110 & $0.24 \mathrm{Al}, 0.008 \mathrm{Ca}$ & 47 \\
\hline FeSi75 & - & 60 & 230 & $1.17 \mathrm{Al}, 0.22 \mathrm{Ca}$ & 18 \\
\hline FeSi75 & 458 & 2 & - & $0.18 \mathrm{Al}, 0.06 \mathrm{Ca}$ & 21 \\
\hline FeSi75 & $160-3600$ & - & - & $0.004-1.4 \mathrm{Al}, 0.006-0.11 \mathrm{Ca}$ & 6 \\
\hline FeSi75 & - & $<200$ & $<400$ & $<1.5 \mathrm{Al},<0.6 \mathrm{Ca}$ & 48 \\
\hline FeSi75 & - & $\leq 500$ & $\leq 500$ & $\leq 1.25 \mathrm{Al}$ & 49 \\
\hline FeSi75 & - & 20 & - & $0.1 \mathrm{Al}, 0.07 \mathrm{Ca}$ & 50 \\
\hline FeSi75 & 160 & 10 & 10 & $<0.5 \mathrm{Al}$ & 45 \\
\hline FeSi75 & - & - & - & $0.02-3.49 \mathrm{Al}, 0.01-1.75 \mathrm{Ca}$ & 51 \\
\hline FeSi75 & - & 30 & 180 & $0.12 \mathrm{Ca}$ & 52 \\
\hline FeTi72 & - & 80 & 120 & $3.14 \mathrm{Al}$ & 18 \\
\hline FeTi35 & 6476 & 221 & - & $5.05 \mathrm{Al}, 0.22 \mathrm{Ca}$ & 21 \\
\hline FeTi35 & - & $\leq 500$ & $\leq 1000$ & $\leq 4.6 \mathrm{Al}$ & 49 \\
\hline FeTi70 & 1859 & 65 & - & $2.48 \mathrm{Al}, 1.83 \mathrm{~V}$ & 21 \\
\hline FeTi70 & $>3000$ & $\leq 20$ & - & $3.3 \mathrm{Al}$ & 20 \\
\hline FeTi70 & - & 100 & 100 & $0.2 \mathrm{Al}$ & 53 \\
\hline FeTi72 & - & 80 & 120 & $3.14 \mathrm{Al}$ & 18 \\
\hline MCFeMn & $110-1710$ & 100 & 1800 & - & 19 \\
\hline LCFeMn & - & 250 & 260 & - & 48 \\
\hline LCFeMn & 360 & 164 & - & $0.22 \mathrm{Al}$ & 21 \\
\hline LCFeMn & - & 80 & - & $0.063 \mathrm{Al}, 0.34 \mathrm{Ca}, 0.25 \mathrm{Mg}$ & 50 \\
\hline HCFeMn & 3426 & 34 & - & $0.22 \mathrm{Al}$ & 21 \\
\hline HCFeMn & - & $\leq 500$ & $\leq 3500$ & - & 23 \\
\hline MCFeMn & - & $\leq 200$ & $\leq 3000$ & & \\
\hline LCFeMn & - & $\leq 200$ & $\leq 3000$ & & \\
\hline $\mathrm{LC}(\mathrm{HC}) \mathrm{FeMn}$ & - & $80-100$ & $480-3000$ & $0.09-2.44 \mathrm{Si}$ & 54 \\
\hline LCFeMn & $3300-11,500$ & - & 1600 & - & 4 \\
\hline MC FeMn & $1700-8200$ & - & 1800 & - & 4 \\
\hline MC FeMn & $100-8900$ & $30-50$ & 1600 & $0.03 \mathrm{Al}$ & 7 \\
\hline LC FeMn & $40-11,100$ & $30-40$ & 1600 & $0.05 \mathrm{Al}$ & 7 \\
\hline SiMn & - & 160 & - & $0.006 \mathrm{Al}, 0.003 \mathrm{Ca}$ & 50 \\
\hline SiMn & - & $\leq 400$ & $\leq 2000$ & - & 23 \\
\hline SiMn & - & 59 & 460 & $0.2 \mathrm{Ti}$ & 18 \\
\hline SiMn & 1500 & $30-90$ & $500-800$ & $0.015 \mathrm{Al}, 0.02-0.035 \mathrm{Mg}, 0.25 \mathrm{Ti}$ & 10 \\
\hline $\mathrm{HCFeCr}$ & - & 320 & 270 & - & 17 \\
\hline $\mathrm{HCFeCr}$ & - & $\leq 500$ & $\leq 300$ & - & 23 \\
\hline $\mathrm{HCFeCr}$ & 200 & 120 & 170 & $5.57 \mathrm{Si}, 0.28 \mathrm{Ti}$ & 5 \\
\hline $\mathrm{LCFeCr}$ & - & $\leq 250$ & $\leq 300$ & — & 23 \\
\hline $\mathrm{LCFeCr}$ & - & 70 & 230 & - & 17 \\
\hline $\mathrm{LCFeCr}$ & 780 & 20 & 900 & $0.05 \mathrm{Al}, 0.25 \mathrm{Mn}$ & 47 \\
\hline $\mathrm{LCFeCr}$ & 650 & 80 & 200 & $0.03 \mathrm{Al}, 0.65 \mathrm{Mn}$ & 47 \\
\hline $\mathrm{LCFeCr}$ & 690 & 70 & 400 & $0.01 \mathrm{Al}, 0.55 \mathrm{Mn}$ & 47 \\
\hline $\mathrm{LCFeCr}$ & - & $\leq 500$ & $\leq 500$ & $\leq 0.01 \mathrm{Al}$ & 49 \\
\hline $\mathrm{LPFeCr}$ & 2100 & 280 & 100 & $1.89 \mathrm{Si}, 0.13 \mathrm{Ti}$ & 5 \\
\hline $\mathrm{FeNb}$ & - & 500 & 600 & $1 \mathrm{Al}, 0.82 \mathrm{Ti}$ & 18 \\
\hline $\mathrm{FeNb}$ & 354 & 106 & - & $0.94 \mathrm{Al}, 0.69 \mathrm{Mg}, 1.39 \mathrm{Mo}, 0.43 \mathrm{Ti}$ & 21 \\
\hline $\mathrm{FeNb}$ & - & $\leq 500$ & $\leq 1000$ & $\leq 1 \mathrm{Al}$ & 49 \\
\hline FeMo & 3260 & 530 & 400 & $0.1 \mathrm{Si}$ & 22 \\
\hline FeMo & - & $<500$ & $<700$ & - & 55 \\
\hline FeMo & 6047 & 614 & - & $0.85 \mathrm{Al}$ & 21 \\
\hline FeMo & - & 1800 & 1000 & $1 \mathrm{Si}$ & 54 \\
\hline FeMo & - & 1000 & 500 & $\leq 1.5 \mathrm{Si}$ & 56 \\
\hline $\mathrm{FeV}$ & - & 800 & 700 & $2.1 \mathrm{Al}, 1.8 \mathrm{Si}$ & 57 \\
\hline FeV40 & - & 600 & 1000 & $1 \mathrm{Al}, 2 \mathrm{Si}$ & 29 \\
\hline FeV50 & - & $\leq 500$ & $\leq 500$ & $\leq 1.5 \mathrm{Al}$ & 49 \\
\hline FeV50 & - & 500 & 1000 & $0.8 \mathrm{Al}, 2.5 \mathrm{Si}$ & 29 \\
\hline FeV80 & - & 500 & 600 & $1.5 \mathrm{Al}, 1.5 \mathrm{Si}$ & 29 \\
\hline FeV80 & 7140 & 210 & 180 & $3 \mathrm{Al}, 1.2 \mathrm{Si}, 0.25 \mathrm{Ca}$ & 22 \\
\hline $\mathrm{FeP}$ & 1390 & 78 & - & $2.03 \mathrm{Mn}, 1.97 \mathrm{Ti}$ & 21 \\
\hline $\mathrm{FeB}$ & 500 & 100 & 150 & $<3 \mathrm{Al}, 2 \mathrm{Si}$ & 22 \\
\hline
\end{tabular}




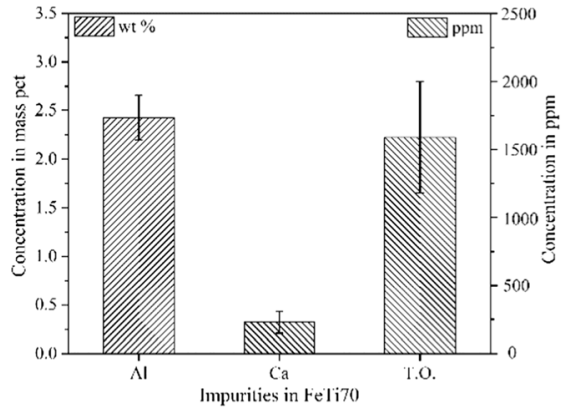

(a)

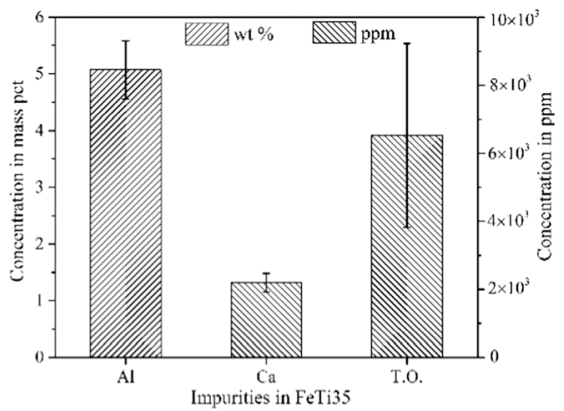

(b)

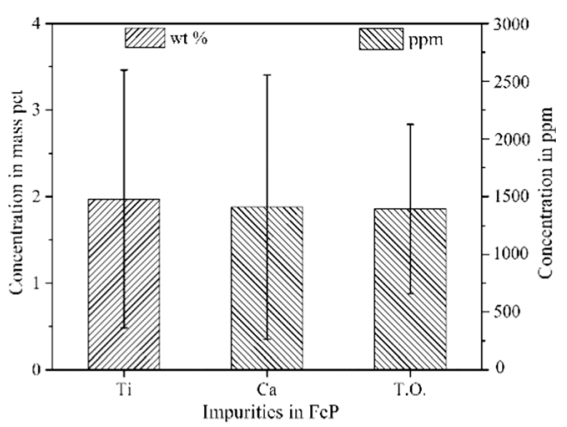

(c)

Fig. 7 - Concentrations of $\mathrm{Al}, \mathrm{Ca}$, Ti and total O (T.O.) in (a) FeTi70, (b) FeTi35 and (c) FeP alloys. Reprinted with permission from Ref. [41].

Table III. Cleanliness Requirements for Various Ferroalloys ${ }^{[64]}$

\begin{tabular}{lll}
\hline Steel Grades & Ferroalloys & \multicolumn{1}{c}{ Requirements } \\
\hline Wire Steel & SiMn & $\mathrm{P}<0.15, \mathrm{~S}<0.04, \mathrm{Al}<0.05, \mathrm{Ti}<0.02$ \\
& FeSi & $\mathrm{P}<0.05, \mathrm{~S}<0.02, \mathrm{Al}<0.05, \mathrm{Ti}<0.02$ \\
Automobile Steel & MCFeMn & $\mathrm{P}<0.2, \mathrm{~S}<0.03, \mathrm{Al}<0.05, \mathrm{Ti}<0.02$ \\
& MCFeMn & $\mathrm{P}<0.2, \mathrm{~S}<0.03, \mathrm{Al}<0.05, \mathrm{Ti}<0.02$ \\
& LCFeMn & $\mathrm{P}<0.02, \mathrm{~S}<0.03, \mathrm{C}<0.03$ \\
Pipeline Steel & FeNi & $\mathrm{P}<0.03, \mathrm{~S}<0.02, \mathrm{C}<0.05, \mathrm{Si}<1.5$ \\
& MCFeMn & $\mathrm{P}<0.05, \mathrm{~S}<0.03, \mathrm{C}<0.05, \mathrm{Si}<2.5$ \\
& FeTi & $\mathrm{P}<0.2, \mathrm{~S}<0.03$ \\
& FeNb & $\mathrm{P}<0.05, \mathrm{~S}<0.03, \mathrm{C}<0.1, \mathrm{Si}<4.5$ \\
& FeMo & $\mathrm{P}<0.05, \mathrm{~S}<0.03, \mathrm{C}<0.05$ \\
& $\mathrm{FeV}$ & $\mathrm{P}<0.04, \mathrm{~S}<0.1$ \\
& & $\mathrm{P}<0.07, \mathrm{~S}<0.04, \mathrm{C}<0.4, \mathrm{Si}<2.0$ \\
\hline
\end{tabular}

\section{Trace metallic elemental impurities}

Except for the main component which is present in ferroalloys, other trace elements such as $\mathrm{Ca}, \mathrm{Al}, \mathrm{Ti}, \mathrm{Mn}$, $\mathrm{Mg}$ are also present as impurities in different ferroalloys. Although their contents are not high, they can play a crucial role in influencing the inclusion characteristics after the addition of ferroalloys to steel melt. It should be pointed out that there are certain elements such as especially $\mathrm{Ca}^{[58]}$ and $\mathrm{Mg}^{[59,60]}$ which can affect the quality of steel, even when being present in minor quantities.

It is well known that FeSi alloys contain impurities such as $\mathrm{Al}$ and $\mathrm{Ca}$, which significantly affect the formation of inclusions in steels. FeTi alloys mainly contain $\mathrm{Al}$ (2.2 to 5.6 mass pct) and $\mathrm{Ca}(0.2$ to 1.5 mass pct) impurities (Figures 7(a) and (b)), but some ferroalloys also contain $\mathrm{V}$. The reason might be that FeTi alloys are usually manufactured by alloying titanium sponge and scrap (mainly $\mathrm{Ti}-6 \mathrm{Al}-4 \mathrm{~V}$ ) with iron or aluminothermic reduction method. ${ }^{[61]}$ In addition, a complex Al and $\mathrm{Ti}$ deoxidation would influence the morphology of the resulting inclusions. ${ }^{[62,63]}$

In FeMn and SiMn alloys, no obvious trace elements are typically present. In terms of $\mathrm{FeNb}$ alloys, the elemental impurities present in significant amounts are $\mathrm{Al}, \mathrm{Mg}, \mathrm{Ca}$ and Mo. ${ }^{[21]}$ In FeV alloys, the common impurity elements are $\mathrm{Si}$ (1.2 to 2.4 mass pct) and $\mathrm{Al}(0.8$ to 3 mass pct), while the impurities in FeMo alloys are $\mathrm{Si}, \mathrm{Cr}$ and $\mathrm{Cu}$. It has also been found that FeP alloys contain impurities such as $\mathrm{Ca}(0.4$ to 3.4 mass pet) and
Ti (0.5 to 3.5 mass pct) (Figure 7(c)). These elemental impurities might originate from the phosphate rock if they are not oxidized during the secondary treatment of the FeP production.

These impurities can undergo complex reactions to form inclusions when ferroalloys are introduced to steel melt. Furthermore, their behaviour would depend upon the oxygen affinity. Specifically, Ca, Al, Ti, Si and Mn all have a strong affinity to oxygen, which leads to a formation of inclusions when the ferroalloy is added to a steel melt. In addition, elements such as $\mathrm{Al}, \mathrm{Ca}$ and $\mathrm{Ti}$ can lead to a modification of existing inclusions. Therefore, the exact quantity of these elements in the ferroalloy should be known before their additions to liquid steel.

It is also necessary to know the amount of especially those elements which even in smaller amounts can affect the inclusion formations, e.g., $\mathrm{Mg}$. The possibility of impairing the steel cleanliness through ferroalloy additions will increase if the impurity contents in ferroalloys are high. Therefore, elements in ferroalloys have mutual restrictions. For instance, the Al content in ferroalloys should be low when added in Si-deoxidized steels. The $\mathrm{FeCr}$ alloys used in titanium-restricted steel grades must have a low $\mathrm{Ti}$ content, which often is restricted to 30 ppm. ${ }^{[42]}$ FeMn alloys with low $\mathrm{Si}$ contents should be added in steels used for deep drawing, which requires a restriction on the Si level. Overall, each clean steel has its particular requirements with respect to element contents in the ferroalloys, as shown in Table III. 


\section{B. Inclusions in Different Ferroalloys and Their Effects on the Steel Cleanliness}

Steels are alloyed with suitable alloying elements such as $\mathrm{Mn}, \mathrm{Cr}, \mathrm{Mo}, \mathrm{V}, \mathrm{Ti}, \mathrm{Nb}$ and $\mathrm{Ni}$, which will enable that the steel solidifies in a manner so that the desired structure is obtained. This, in turn, will influence the mechanical properties such as hardness, ductility and wear resistance. It has been widely acknowledged that non-metallic inclusions are the main impurities present in ferroalloys. When ferroalloys are added into the steel melt, the inclusions from the added alloys will undergo a series of physical (such as melting and dissolving) and chemical processes.

Some of the inclusions deriving from the ferroalloys will float up quickly and be removed by the slag when the alloy is melted by the surrounding hot steel; some will melt and partially or completely dissolved in steel; some will react with other inclusions or elements (dissolved $\mathrm{O}, \mathrm{S}$ as well as other deoxidation and alloying elements) to form new complex inclusions; some will remain solid and act as nucleation sites or they will collide with each other and form clusters. Besides, inclusions will form at locations with high concentrations of alloying elements and oxygen, after the addition of ferroalloys to steel. Moreover, their behaviour will be affected by several factors such as the temperature, steel composition, oxygen content, deoxidation process, the residence time in the liquid steel, element activity, existing inclusions, and so forth. This part of the review is focused on the results of previous studies concerning the contents of various inclusions in different ferroalloys and the effect of the impurities from ferroalloy on the steel quality.

In general, previous researchers have primarily focused on investigations of inclusions in five types of ferroalloys, namely FeSi, FeMn, SiMn, FeTi and FeCr. These are consumed to a far greater tonnage in steelmaking compared to any other ferroalloys. Besides studying inclusion types, previous investigations have also investigated their behaviours in the steel melt after the addition of these ferroalloys to the melt. In addition to the above five studied ferroalloy types, some other ferroalloys such as FeMo, FeNb, FeV, FeB have also been studied. Table IV presents an overview of previous studies related to the investigations of inclusions in different ferroalloys.

\section{FeSi alloys}

Ferrosilicon is produced carbothermally by reducing silica-rich raw materials (quartz and other silica-rich minerals accompanied by different clay materials) in submerged arc furnaces. Clays are usually particles composed of silica, alumina and water with impurities of $\mathrm{Fe}_{2} \mathrm{O}_{3}, \mathrm{TiO}_{2}, \mathrm{CaO}, \mathrm{MgO}$. Some elements from minerals will end up in the $\mathrm{FeSi}$ metal, especially for minor impurities, which may vary depending on the types and purity of the raw materials used. Typical elements must be controlled by an oxygen refining process and slag treatment. ${ }^{[9]}$
Bi et al. ${ }^{[18]}$ studied the inclusions in FeSi75 alloys using the electrolytic extraction (EE) method. They showed that inclusions consisted of REM oxides containing some amounts of $\mathrm{Si}, \mathrm{Fe}$ and $\mathrm{Ti}, \mathrm{CaSi}$ intermetallic compound containing some $\mathrm{Al}$ and $\mathrm{Ni}, \mathrm{Fe}-\mathrm{Si}-\mathrm{Ti}-\mathrm{Al}$ intermetallic phase, and pure Si phase containing small amounts of $\mathrm{O}$ and Al. As REM oxides have a higher melting point than the steelmaking temperature, further research is needed to clarify what will happen after they enter the molten steel. On the other hand, REM mainly comes from raw materials. Thus, the elements in the raw materials should be controlled to reduce the generation of REM oxides.

$\mathrm{CaSi}$ and $\mathrm{Fe}-\mathrm{Si}-\mathrm{Ti}-\mathrm{Al}$ intermetallic compounds were also detected by Wijk and Brabie. ${ }^{[6]}$ In addition, a pure Si phase was found by Franklin et al. ${ }^{[65]}$ which made up 75 pct of the total phase while the remaining part consisted of a $\mathrm{Fe}-\mathrm{Si}-\mathrm{Al}$ intermetallic phase rich in $\mathrm{Al}$ and $\mathrm{Ca}$. In addition, Li et al. ${ }^{[69]}$ reported that an $\mathrm{Al}-\mathrm{Ca}$ rich phase was found at the interface of the $\mathrm{Si}$ and $\mathrm{Fe}$ phases in a FeSi75 alloy. Al-rich phases and Ca-rich phases were detected in high $\mathrm{Al}$ (1.6 mass pct $\mathrm{Al}$ ) and high $\mathrm{Ca}$ (1.3 mass pet $\mathrm{Ca}$ ) containing FeSi72 alloys, respectively. ${ }^{[70]}$ Similar phases containing $\mathrm{Al}$ and $\mathrm{Ca}$ were found in $\mathrm{FeSi} 45(65)^{[66]}$ and $\mathrm{FeSi} 75^{[67]}$ alloys. Figure 8 shows the typical intermetallic phases found in $\mathrm{FeSi}$ alloys. The effect of $\mathrm{Al}$ and $\mathrm{Ca}$ from $\mathrm{FeSi}$ alloys on the inclusion characteristics are different depending on their compositions, and it will be discussed in detail later.

Pande et al. ${ }^{[21]}$ used an acid 3D method to investigate the inclusions in different ferroalloys. As the dissolution technique for FeSi75 alloy was quite a cumbersome process, therefore, this method was not suitable to be used for a FeSi alloy. Compounds of $\mathrm{Ca}-\mathrm{Mg}-\mathrm{Al}-\mathrm{O}$ and pure $\mathrm{SiO}_{2}$ were found based on microstructure analyses. In addition, complex compounds of $\mathrm{Al}-\mathrm{Ca}-\mathrm{O},(\mathrm{Al}, \mathrm{Ca}$, $\mathrm{Si})_{x} \mathrm{O}_{y},(\mathrm{Al}, \quad \mathrm{Mg})_{x} \mathrm{O}_{y}$ were found in $\mathrm{FeSi65}$ (75) alloys. ${ }^{[45,65]}$ In addition, Vorob'ev ${ }^{[54]}$ found $\mathrm{SiC}$, $\mathrm{Al}_{2} \mathrm{O}_{3}$, and $\mathrm{SiO}_{2}$ inclusions in $\mathrm{FeSi75}$ alloys. Horn et al. ${ }^{[67]}$ reported that phosphides inclusions containing $\mathrm{Al}, \mathrm{Ca}$ and $\mathrm{Mg}$ in FeSi75 alloys. These inclusions usually provided excellent nucleation sites for microcracks during cooling, which explained why these inclusions were always found within microcracks.

A recent paper ${ }^{[47]}$ reported that the number density of $\mathrm{SiO}_{2}$ inclusions was about $49.5 / \mathrm{mm}^{-2}$ and that the largest inclusion reached a size of about $187 \mu \mathrm{m}$ on the metal surface after electrolytic extraction (EE). Thus, the addition of FeSi alloys can inevitably increase the oxygen content in the steel due to the presence of a large number of $\mathrm{SiO}_{2}$ inclusions. This, in turn, will contribute to the formation of new inclusions. Correspondingly, the presence of silicates in FeSi is self-evident. Other oxides containing $\mathrm{CaO}, \mathrm{MgO}, \mathrm{Al}_{2} \mathrm{O}_{3}$ originate from impurity oxides present in primary raw materials or can be formed as secondary oxidation products. The typical inclusions found in FeSi alloys are shown in Figure 9.

As FeSi is a commonly used deoxidizer, several studies regarding the $\mathrm{FeSi}$ deoxidation in the steel have been carried out. Various researchers have investigated the behaviour of inclusions characteristics in steel melt 


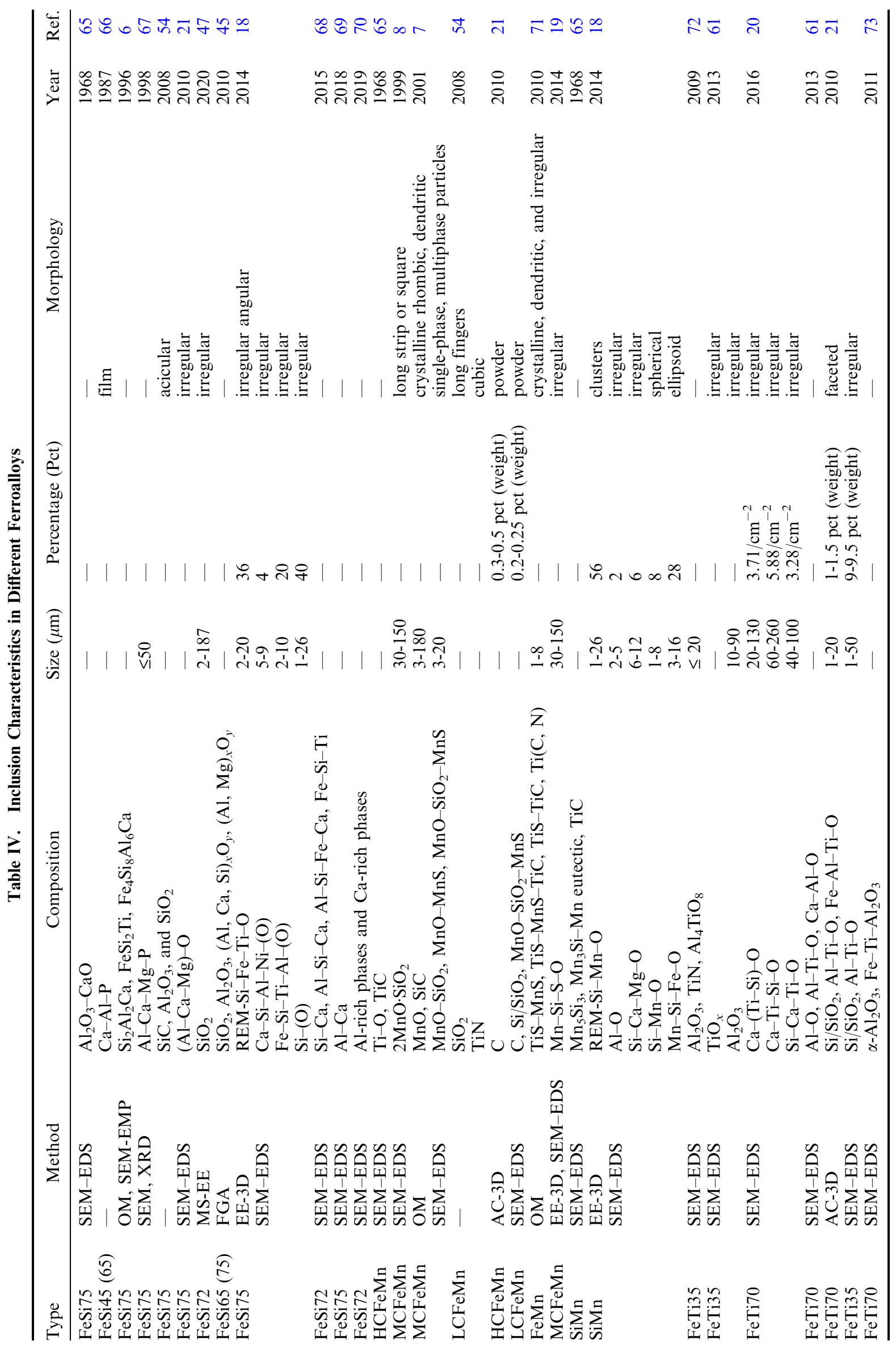




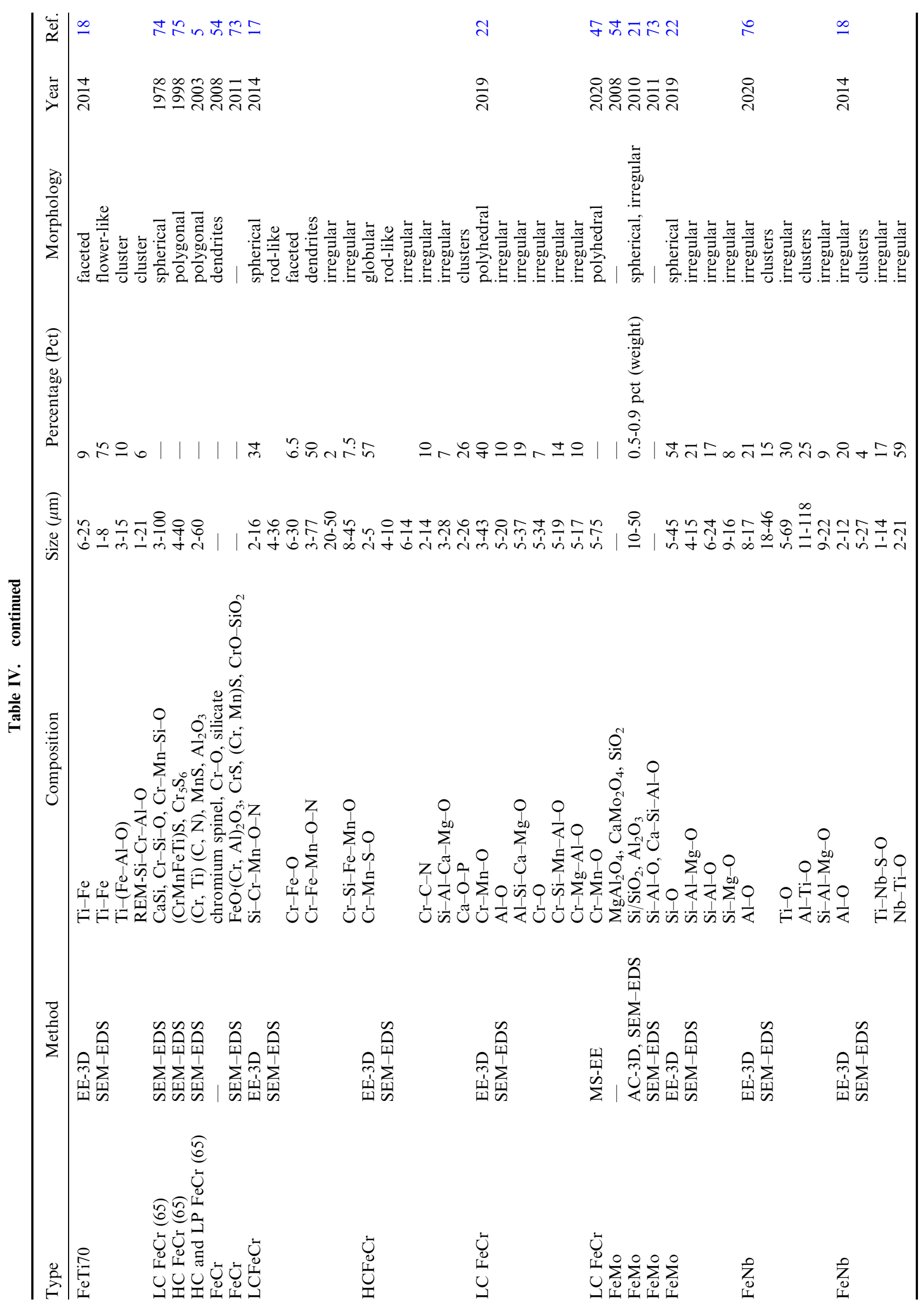




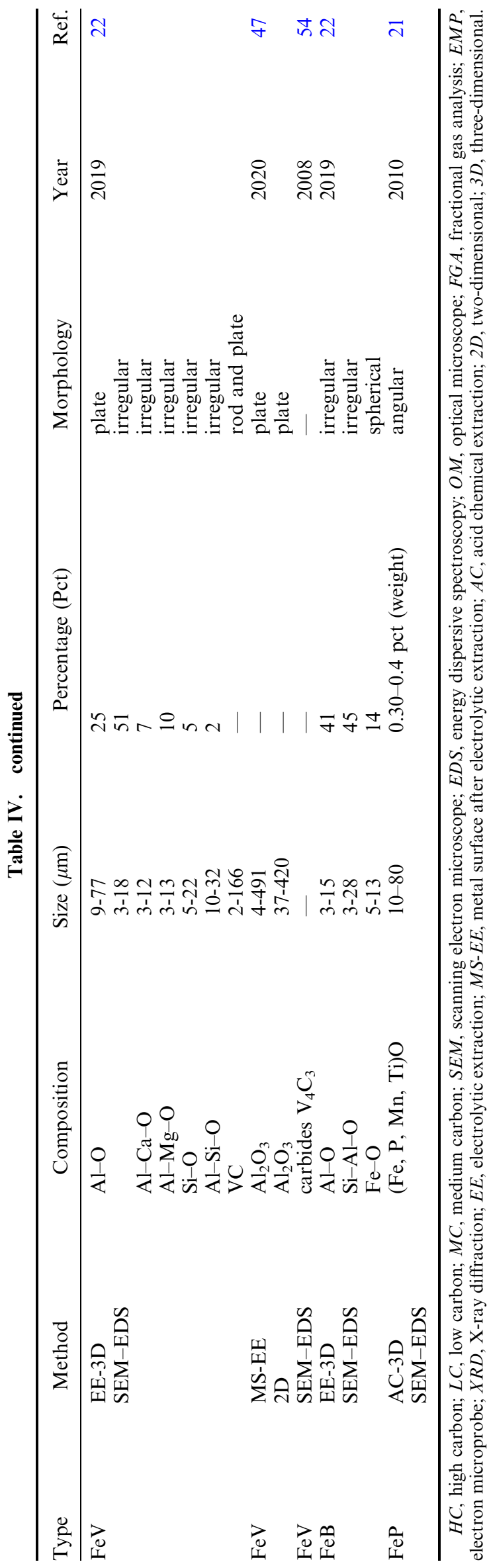

after the addition of FeSi alloys. The transient inclusion formation immediately after a FeSi75 addition and prior to macro-mixing/homogenisation in low carbon-silicon killed steel was studied using a novel experimental laboratory technique, ${ }^{[48]}$ as shown in Figure 10(a). It was found that the reactions took place at the surface of the existing $\mathrm{FeO}-\mathrm{MnO}-\mathrm{SiO}_{2}$ inclusions in the steel melt, which led to the formation of a $\mathrm{SiO}_{2}$ rich layer. This, in turn, can slow down the further transformation of these inclusions. In addition, soluble [Si] in steel would react with the $\mathrm{FeO}$ inside the inclusion to form more $\mathrm{SiO}_{2}$ inclusions. Thereby, the liquid inclusions shifted toward the silica saturation. The thermodynamic prediction showed that the majority of inclusions should be solid $\mathrm{SiO}_{2}$ inclusions containing some liquid phase inclusions $\left(\sim 70\right.$ mass pet $\mathrm{SiO}_{2}$ with $<10$ mass pet $\mathrm{Al}_{2} \mathrm{O}_{3}, 3$ to 5 mass pet $\mathrm{FeO}$ and 3 to 5 mass pet $\mathrm{MnO}$ ), as shown in Figures 10(b) and (c). Therefore, if the steel is only deoxidized using $\mathrm{FeSi}$, newly formed $\mathrm{SiO}_{2}$ and inherited $\mathrm{SiO}_{2}$ inclusions from the $\mathrm{FeSi}$ alloys in the steel can cause a big problem, as these solid inclusions would be difficult to transform to less harmful liquid inclusions during ladle treatment.

In Si-killed steels, silicate inclusions with low melting temperatures were preferred and Al-containing alloys were prohibited. ${ }^{[79-81]}$ However, there was a certain amount of $\mathrm{Al}$ or $\mathrm{Ca}$ that was present in the $\mathrm{FeSi}$, which was usually ignored. A study of the influence of $\mathrm{FeSi}$ quality on the steel cleanliness was performed by Grigorovich et al., ${ }^{[45]}$ who found that additions of FeSi65 ( $\mathrm{Al}>2$ mass pct) and FeSi75 ( $\mathrm{Al}<0.5$ mass pct) in the melt lead to an oxygen decrease from 50 to 60 to 40 to 45 and 15 to $20 \mathrm{ppm}$, respectively. They also found that there was a high quantity of $\mathrm{Al}_{2} \mathrm{O}_{3}$ inclusions present in the melt after the addition of a FeSi65 alloy. Thus, the use of a high-quality FeSi75 alloy resulted in a low oxygen content and the formation of favourable plastic silicate inclusions in the steel. In addition, Franklin et al. ${ }^{[65]}$ used the electron probe microanalyzer to trace the sources of inclusions from a FeSi75 alloy to steel. They also found high alumina contents in the inclusions observed in the steel melt immediately after the FeSi addition. This was found to be due to the presence of $\mathrm{Al}$ ( 1 to 2 mass pct) in FeSi. Another example discussed the $\mathrm{FeSi}$ addition to $\mathrm{Si}-\mathrm{Mn}$ killed steels. ${ }^{[3]}$ The results showed that $\mathrm{Al}$ content in steel increased when FeSi containing 1 mass pct $\mathrm{Al}$ was added to steel. Furthermore, that solid oxides, spinel and $\mathrm{Ca}-\mathrm{Mg}-\mathrm{Al}$-silicates started to form when the amount of added $\mathrm{FeSi}$ was increased.

Wijk and Brabie ${ }^{[6]}$ performed laboratory experiments to study the influence of FeSi75 alloy (standard, granulated, high purity) additions on the inclusion characteristics in steel melts. They observed that silica inclusions were formed after the addition of a high-purity FeSi75 alloy (0.004 mass pet Al, 0.006 mass pet $\mathrm{Ca}$, 0.016 mass pet $\mathrm{O}$ ). Furthermore, alumina, silica and alumina-silicates were formed when a granulated $\mathrm{FeSi}$ alloy containing $\mathrm{Al}$ (1.34 to 1.4 mass pet) was used. In addition, this resulted in an increase of the $\mathrm{Al}$ content to around $30 \mathrm{ppm}$, which was in agreement with the results of Grigorovich et al. ${ }^{[45]} \mathrm{A}$ comparison of results for 

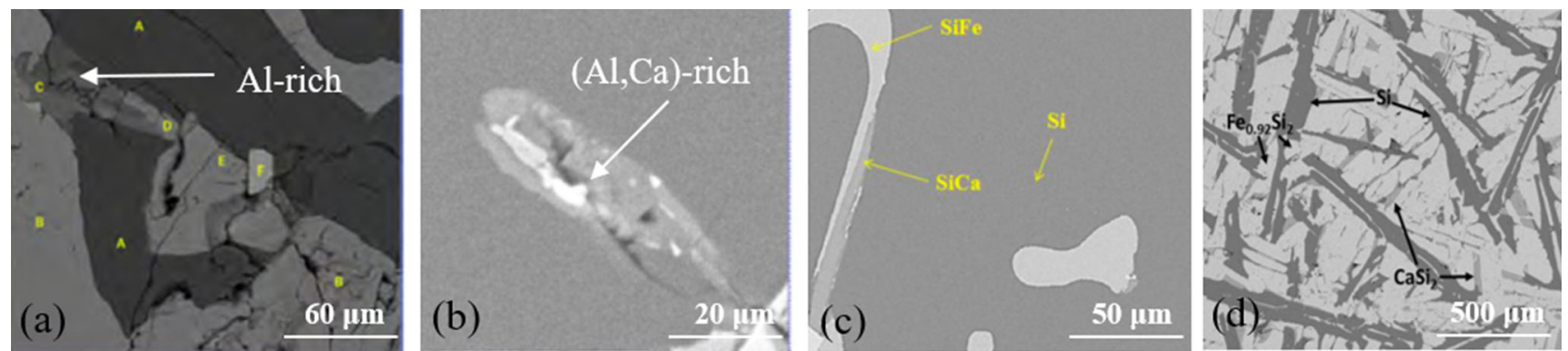

Fig. 8-Impurity phases in commercial FeSi alloys, (a) Al-rich phases, reprinted from Ref. [68], (b) Al-Ca rich phases, reprinted with permission from Ref. [69], (c) Ca-rich phases, reprinted with permission from Ref. [77], and (d) Ca-rich phases, reprinted from Ref. [78].

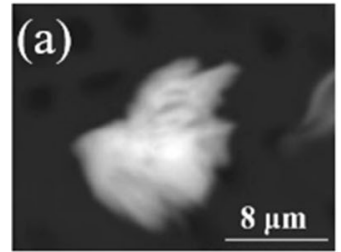

REM-Si-Fe-Ti-O (2-20 $\mu \mathrm{m})$

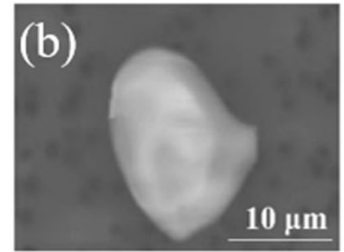

$\mathrm{Ca}-\mathrm{Si}-\mathrm{Al}-\mathrm{Ni}-(\mathrm{O})(5-9 \mu \mathrm{m})$

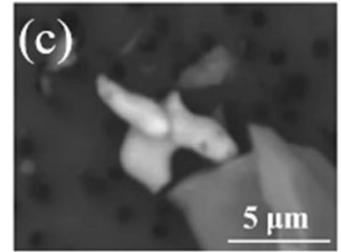

$\mathrm{Fe}-\mathrm{Si}-\mathrm{Ti}-\mathrm{Al}-\mathrm{O})(2-10 \mu \mathrm{m})$

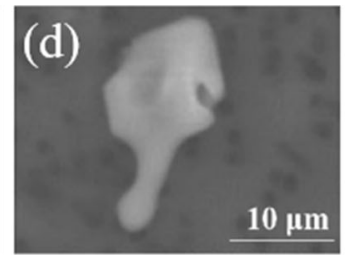

$\mathrm{Si}-(\mathrm{O})(1-26 \mu \mathrm{m})$

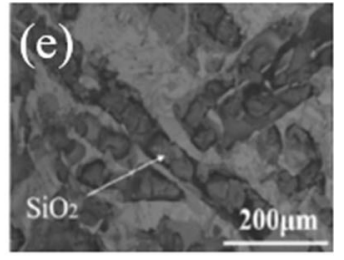

$\mathrm{SiO}_{2}(19-187 \mu \mathrm{m})$

Fig. 9-Classification of inclusions in FeSi alloys, $(a)$ through $(d)$ reprinted with permission from Ref. [18], and (e) reprinted from Ref. [47], under the terms of the Creative Commons CC BY license.
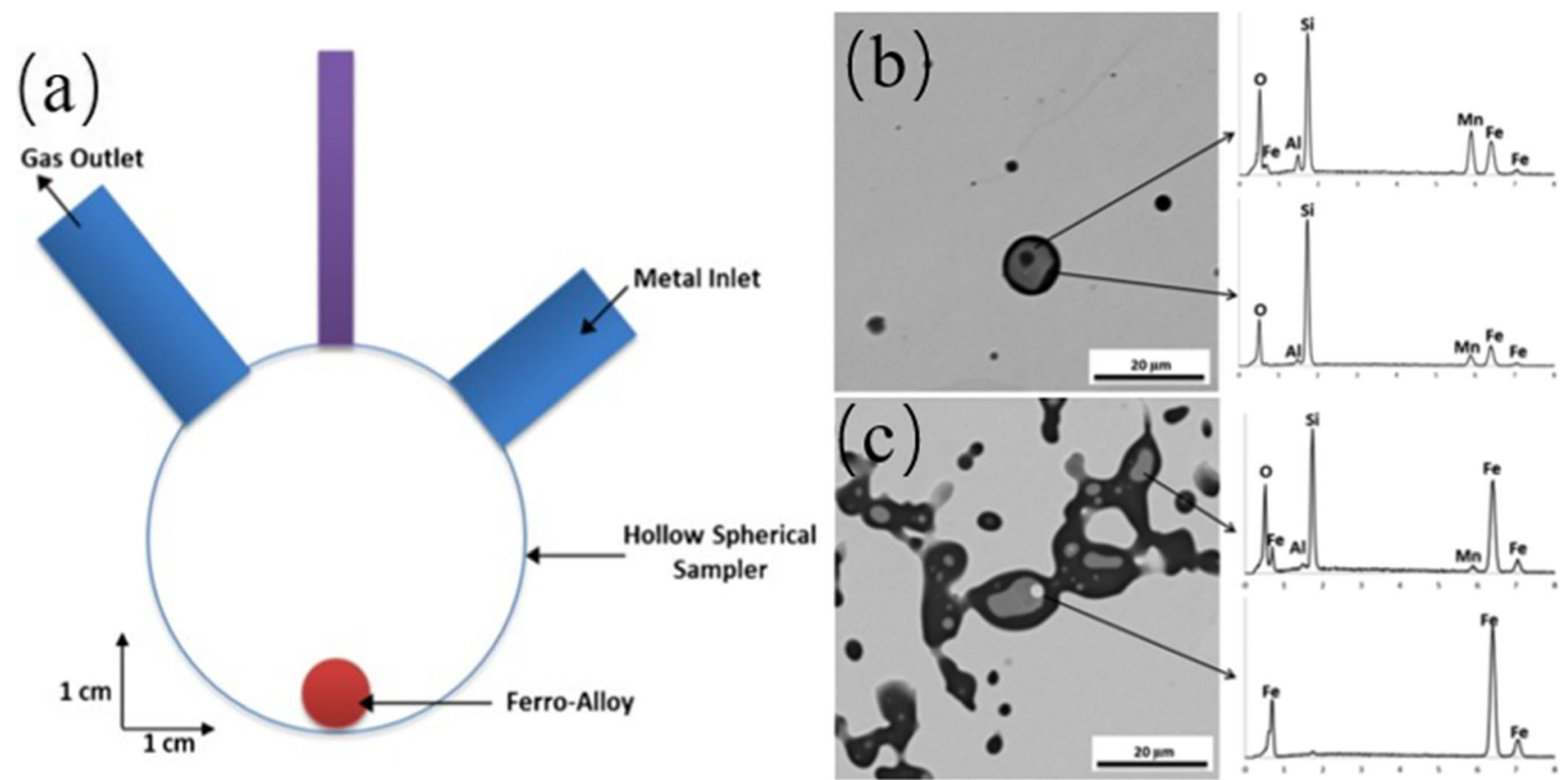

Fig. 10 - Schematic diagram of samplers used for $\mathrm{FeSi}$ dissolution study (a) and a liquid phase $\left(\mathrm{SiO}_{2}-\mathrm{MnO}-\mathrm{FeO}_{-}-\mathrm{Al}_{2} \mathrm{O}_{3}\right)$ within a $\mathrm{SiO} \mathrm{O}_{2}$ inclusion (b), and a $\mathrm{Fe}$ particle trapped within a $\mathrm{SiO}_{2}-\mathrm{FeO}$ inclusion (c). Reprinted with permission from Ref. [48].

three different specifications of FeSi75 alloys showed that the addition of a high purity FeSi75 alloy resulted in fewer inclusions, especially of the lower size fractions and a lower rate of decrease of the total oxygen, compared to the other two alloy qualities.

Similar research was performed by Park and Kang, ${ }^{[33]}$ where they compared the effect of high $\mathrm{Al}$ and low $\mathrm{Al}$ FeSi additions (FeSi-H: 1.13 mass pet $\mathrm{Al}$ and FeSi-L: 0.17 mass pct $\mathrm{Al}$ ) on the inclusions in $16 \mathrm{Cr}-14 \mathrm{Ni}-\mathrm{Si}$ stainless steels based on laboratory experiments. The evolutions of inclusions in the steel melt deoxidized by FeSi-H and FeSi-L alloys are shown in Figure 11. The addition of FeSi-H resulted in a decrease of the $\mathrm{MnO}$ content from about 45 mass pet to 5 mass pct and an increase of the $\mathrm{Al}_{2} \mathrm{O}_{3}$ content in inclusions. However, the use of the $\mathrm{FeSi}-\mathrm{L}$ alloy resulted in a decreased formation of $\mathrm{Al}_{2} \mathrm{O}_{3}$ in the inclusions. Moreover, liquid $\mathrm{MnO}-\mathrm{SiO}_{2}-\mathrm{MgO}$ inclusions were first transformed to 


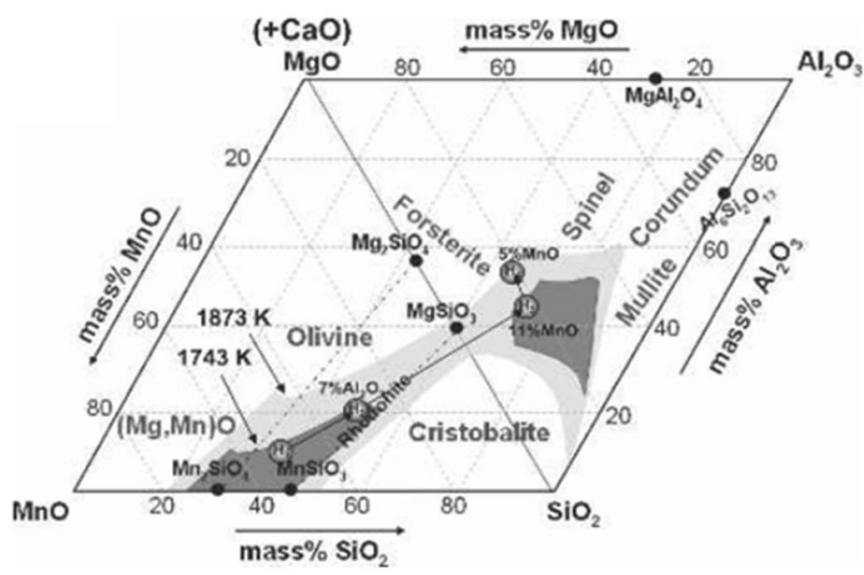

(a)

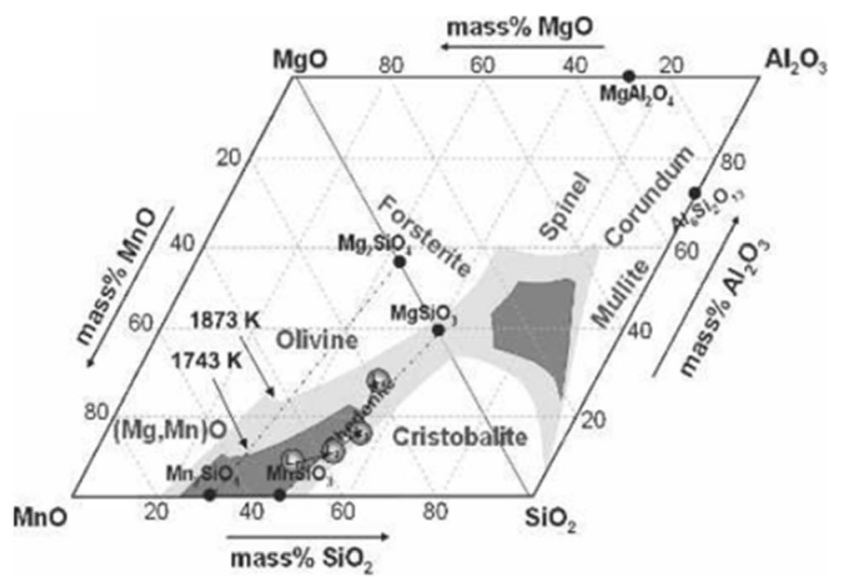

(b)

Fig. 11-Evolution of inclusions in steel deoxidized by FeSi-H (a) and FeSi-L (b) alloys. Reprinted from Ref. [43].

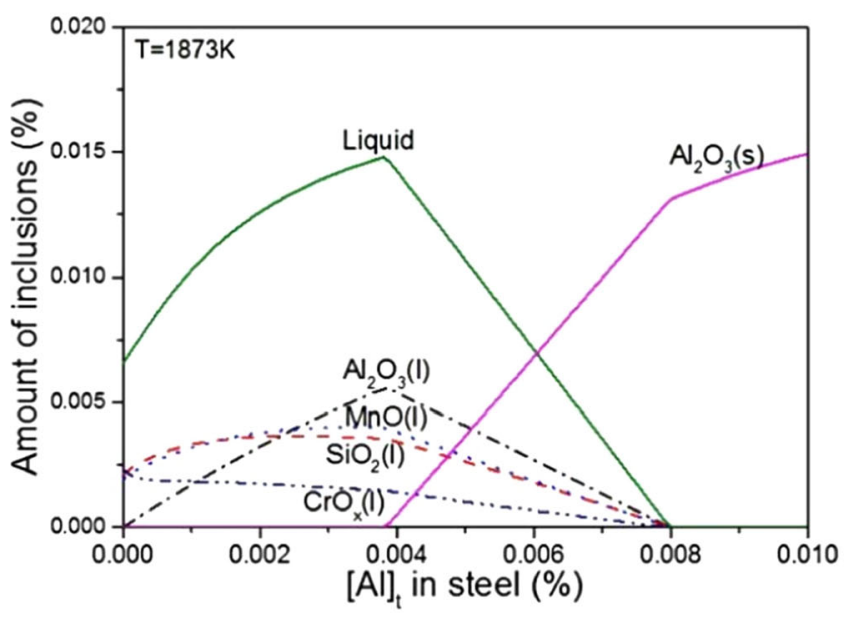

(a)

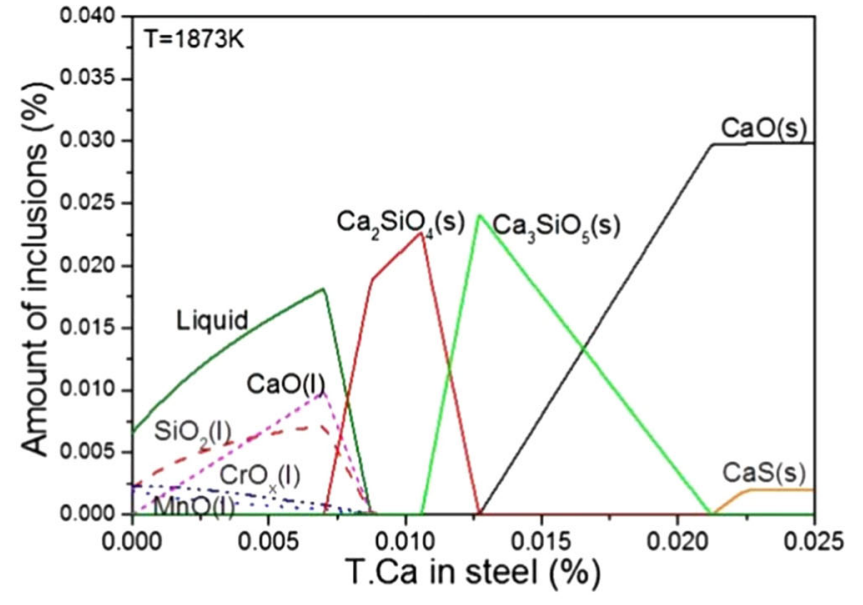

(b)

Fig. 12 - Predicted effect of FeSi additions on the compositions of inclusions in $18 \mathrm{Cr}-8 \mathrm{Ni}$ stainless steels at $1873 \mathrm{~K}\left(1600{ }^{\circ} \mathrm{C}\right)$ : high $\mathrm{Al} \mathrm{FeSi}($ a), high Ca FeSi (b). Reprinted with permission from Ref. [70].

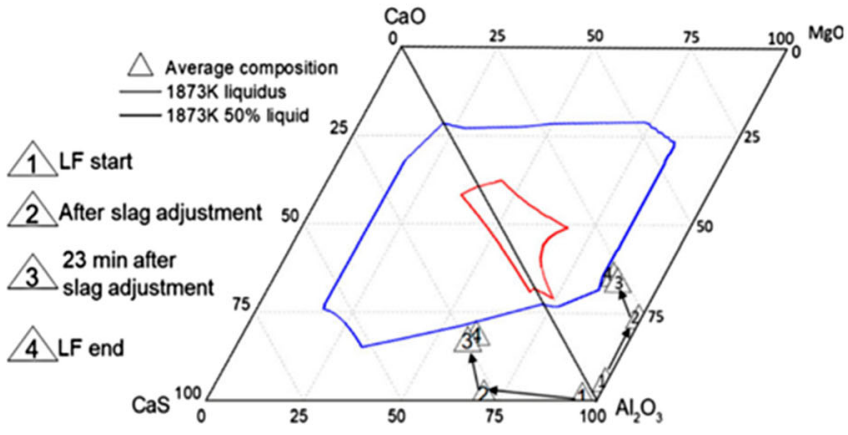

(a)

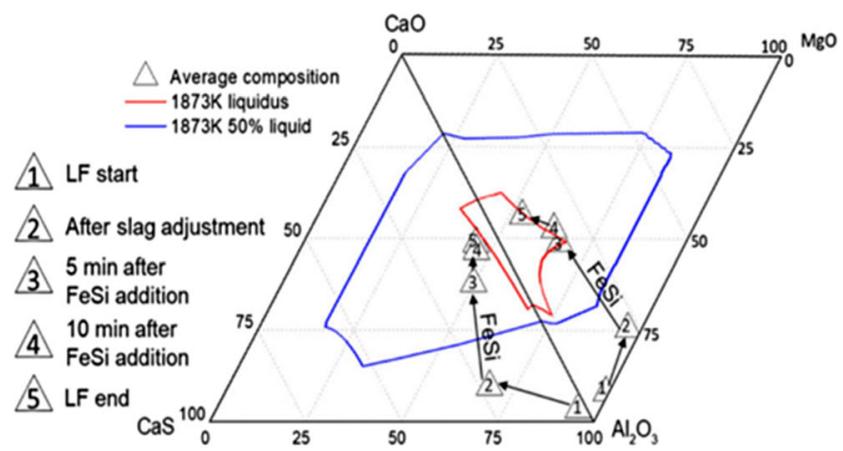

(b)

Fig. 13-Effect of FeSi additions on the inclusion composition during the ladle refining process: $(a)$ without a FeSi addition, and (b) with a FeSi addition. Reprinted with permission from Ref. [69]. 

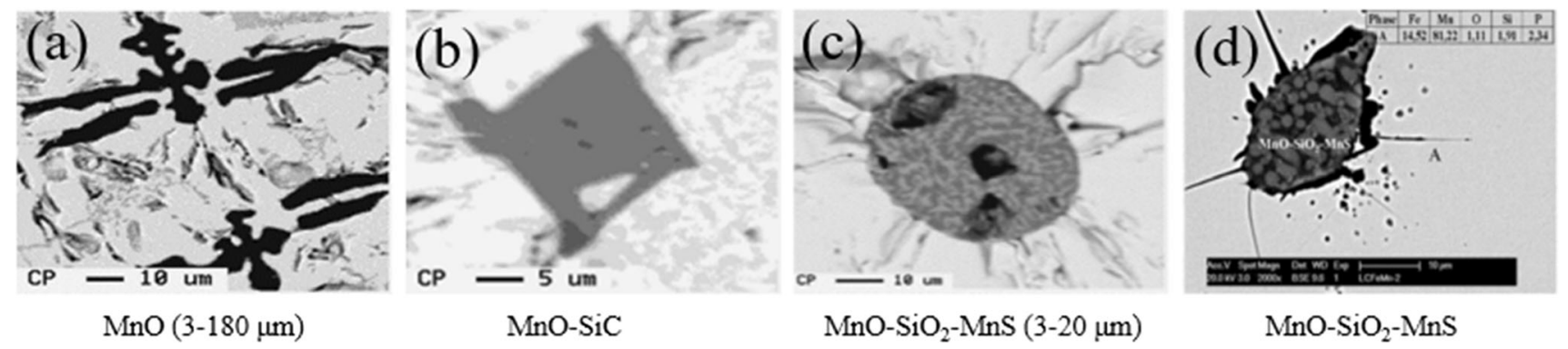

Fig. 14-Typical inclusions found in FeMn alloys, (a) through (c) reprinted from Ref. [87], and (d) reprinted with permission from Ref. [21].

$\mathrm{Mn}$ silicates containing a cristobalite phase and then to rhodonite $\left((\mathrm{Mg}, \mathrm{Mn}) \mathrm{SiO}_{3}\right.$ inclusions as the $\mathrm{Si}$ content was increased when a FeSi-L alloy was used. Their results showed that the types of inclusions cannot only be affected by the $\mathrm{Al}$ content in the FeSi alloy, but also by the Si content in the steel.

Besides the effect of $\mathrm{Al}$ on inclusions, Mizuno et al. ${ }^{[51]}$ systematically investigated the effect of the $\mathrm{Al}$ and $\mathrm{Ca}$ contents in FeSi75 alloys on the composition of inclusions in 304 stainless steels based on laboratory-scale experiments. Four types of FeSi75 alloys were added to a melt, namely: (i) type 1 corresponding to $\mathrm{FeSi}$ without $\mathrm{Al}$ and $\mathrm{Ca}$, (ii) type 2 containing $\mathrm{Al}(0.09$ to 2.91 mass pct), (iii) type 3 containing $\mathrm{Al}$ (1.42 to 3.49 mass pct) and $\mathrm{Ca}$ ( 0.07 to 1.75 mass pet), and type 4 containing $\mathrm{Ca}$ (1.71 mass pct). Specifically, they found that the presence of $\mathrm{Al}$ (2.91 mass pct) in $\mathrm{FeSi}$ alloys resulted in the formation of $\mathrm{Al}_{2} \mathrm{O}_{3}$ inclusions just after the addition of the alloy. Thereafter, these inclusions transformed to $\mathrm{MgO}-\mathrm{Al}_{2} \mathrm{O}_{3}$ spinels if the added $\mathrm{FeSi}$ contained more than 0.5 mass pct Al. They also found that $\mathrm{SiO}_{2}-\mathrm{Al}_{2} \mathrm{O}_{3}-\mathrm{MnO}-\mathrm{CaO}$ inclusions were formed one minute after the addition of type $3 \mathrm{FeSi}$ alloys containing $\mathrm{Al}$ (1.7 mass pct) and $\mathrm{Ca}(0.4$ mass pct). These inclusions were finally transformed into harmless $\mathrm{CaO}-\mathrm{SiO}_{2}-\mathrm{Al}_{2} \mathrm{O}_{3}-\mathrm{MgO}$ spherical inclusions. The results with type $4 \mathrm{FeSi}$ alloys containing 1.7 mass pet $\mathrm{Ca}$ showed a similar tendency as the experiments with type $3 \mathrm{FeSi}$ alloys, namely that the presence of $\mathrm{Ca}$ prevented the formation of spinel inclusions. Therefore, the addition of $\mathrm{FeSi}$ alloys containing $\mathrm{Ca}$ is one of the countermeasures to prevent the formation of spinels in practical industrial situations.

The formation mechanism of inclusions in steels during the deoxidation using $\mathrm{FeSi}$ alloys containing $\mathrm{Al}$ and $\mathrm{Ca}$ has been extensively studied. However, FeSi is also added in a ladle furnace for alloying, so the effect of $\mathrm{Al}$ and $\mathrm{Ca}$ in $\mathrm{FeSi}$ on the inclusion characteristics during the alloying process was recently studied by Li et al.$^{[70]}$ They reported that the $\mathrm{SiO}_{2}-\mathrm{MnO}$ inclusions were hardly influenced by the low $\mathrm{Al}$ ( $<0.02$ mass pet) and $\mathrm{Ca}(<0.05$ mass pct) contents in $\mathrm{FeSi}$ alloys. However, the high $\mathrm{Al}$ (1.6 mass pct) containing FeSi alloy leads to a significantly increased $\mathrm{Al}_{2} \mathrm{O}_{3}$ content in $\mathrm{Al}_{2} \mathrm{O}_{3}$ $\mathrm{SiO}_{2}-\mathrm{MnO}$ inclusions and also lead to the formation of pure $\mathrm{Al}_{2} \mathrm{O}_{3}$ inclusions, which was unexpected in the $\mathrm{Si}-\mathrm{Mn}$-killed stainless steels. The high $\mathrm{Ca}$ containing
FeSi alloy can be used to modify $\mathrm{SiO}_{2}-\mathrm{MnO}$ inclusions to $\mathrm{Al}_{2} \mathrm{O}_{3}-\mathrm{SiO}_{2}-\mathrm{CaO}$ inclusions, but the size of the formed $\mathrm{Al}_{2} \mathrm{O}_{3}-\mathrm{SiO}_{2}-\mathrm{CaO}$ inclusions was larger than that of the $\mathrm{Al}_{2} \mathrm{O}_{3}-\mathrm{SiO}_{2}-\mathrm{MnO}$ inclusions. However, the number density of inclusions was found to decrease. Thermodynamic calculations were also performed to study the effect of $\mathrm{FeSi}$ additions on inclusions, as shown in Figure 12. When the total [Al] content in the molten steel reached $38 \mathrm{ppm}, \mathrm{Al}_{2} \mathrm{O}_{3}$ inclusions started to form. These results were in line with the observed experimental results when a high $\mathrm{Al}$ containing $\mathrm{FeSi}$ alloy was added to steel. As the total [Ca] content in molten steel increased, the $\mathrm{CaO}$ content in inclusions obviously increases. Thus, a low $\mathrm{Al}$ and $\mathrm{Ca}$ containing $\mathrm{FeSi}$ alloy is suggested to be an appropriate alloy to be used for the alloying process in the ladle furnace for Si-Mn-killed steels.

Industrial experiments with and without FeSi75 (1.36 mass pct $\mathrm{Al}$ and 0.67 mass pct $\mathrm{Ca}$ ) additions during ladle refining in the production of line-pipe steels were compared by Li et al. ${ }^{[69]}$ The effect of $\mathrm{FeSi}$ addition on the inclusion composition is presented in Figure 13. In the heat without the addition of $\mathrm{FeSi}$, the inclusions first evolved from $\mathrm{Al}_{2} \mathrm{O}_{3}$ to $\mathrm{MgO} \cdot \mathrm{Al}_{2} \mathrm{O}_{3}$ inclusions and then to half liquid $\mathrm{CaO}-\mathrm{MgO}-\mathrm{Al}_{2} \mathrm{O}_{3}$ inclusions. However, the addition of FeSi can significantly modify $\mathrm{Al}_{2} \mathrm{O}_{3}$ and $\mathrm{MgO} \cdot \mathrm{Al}_{2} \mathrm{O}_{3}$ inclusions to liquid $\mathrm{CaO}-\mathrm{Al}_{2} \mathrm{O}_{3}$ inclusions. Therefore, the addition of Ca-containing FeSi alloys can achieve the same modification effect on $\mathrm{Al}_{2} \mathrm{O}_{3}$ and $\mathrm{MgO} \cdot \mathrm{Al}_{2} \mathrm{O}_{3}$ inclusions as a traditional calcium treatment.

It is widely known that $\mathrm{Al}$ and $\mathrm{Ca}$ are the main impurities found in commercial $\mathrm{FeSi}$ alloys. Both elements have a higher oxygen affinity than silicon, so they can be removed through a liquid silicon oxidation refining process. ${ }^{[82]}$ Their thermodynamic data in liquid $\mathrm{FeSi}$ is of great importance for the refining process. Therefore, some researchers paid attention to this respect. Specifically, Dummy et al. ${ }^{[83,84]}$ determined the activity coefficients of $\mathrm{Al}, \mathrm{Ca}$, and $\mathrm{Si}$ in liquid $\mathrm{Fe}-\mathrm{Si}-\mathrm{Al}-\mathrm{Ca}$ and $\mathrm{FeSi} 65$ alloys. More recently, Tome-Torquemada et al. ${ }^{[55]}$ performed laboratory experiments to determine the activities of $\mathrm{Ca}$ and $\mathrm{Al}$ in liquid FeSi50 alloys, containing minor $\mathrm{Ca}$ and $\mathrm{Al}$ contents. Nevertheless, more research can be done in this area in the future to help the ferroalloy industries to optimize their processes to get purified FeSi alloys. 


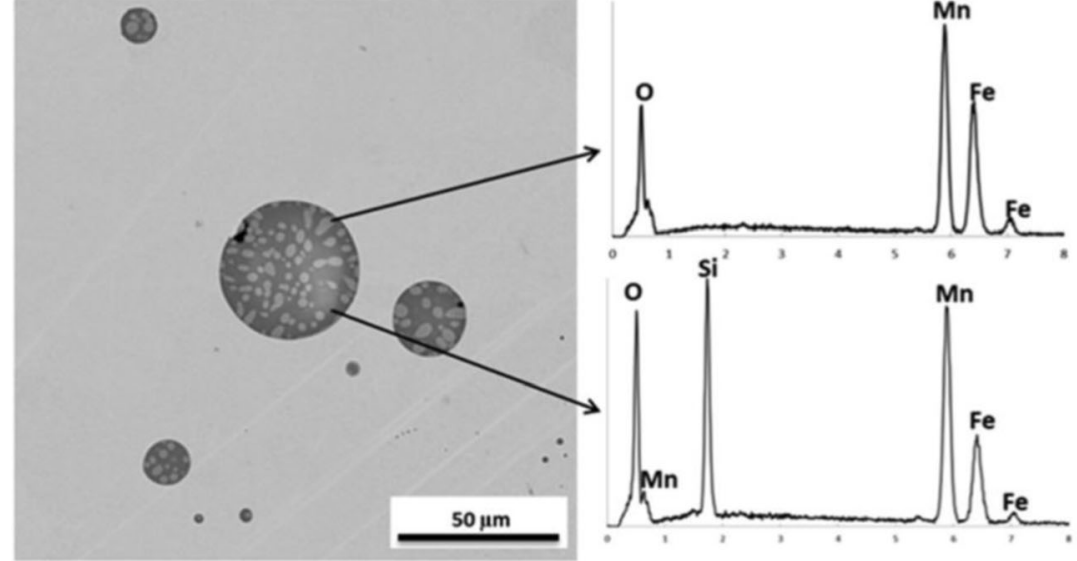

(a)

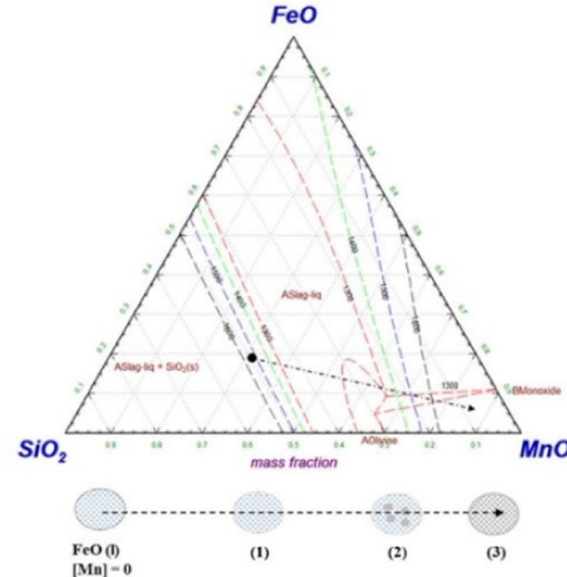

(b)

Fig. 15-Typical inclusion containing a MnO-FeO phase present in the liquid phase $(a)$ and the mechanism of inclusion evolution $(b)$. Reprinted with permission from Ref. [48].

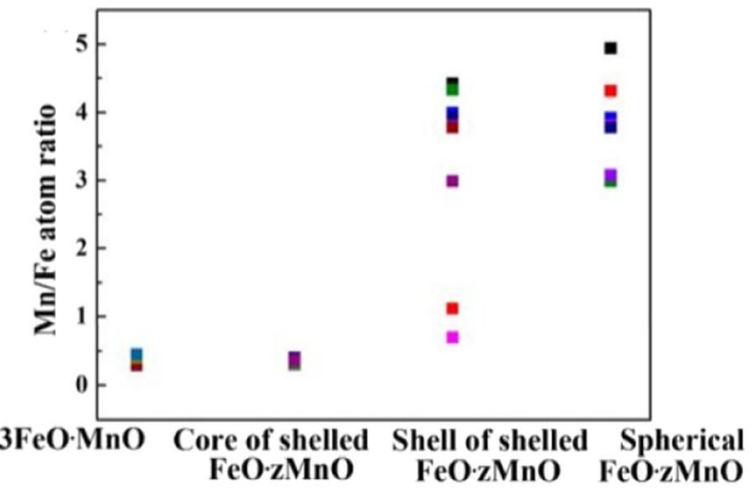

(a)

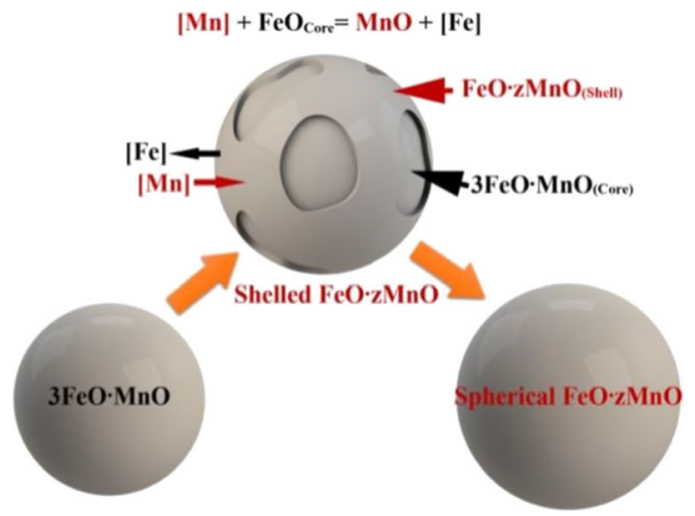

(b)

Fig. 16- $\mathrm{Fe} / \mathrm{Mn}$ ratio in the core and shell of $\mathrm{FeO}-\mathrm{MnO}$ inclusions $(a)$ and schematic illustration of the evolution of $\mathrm{FeO}-\mathrm{MnO}$ inclusions $(b)$. Reprinted from Ref. [88], under the terms of the Creative Commons CC BY license.

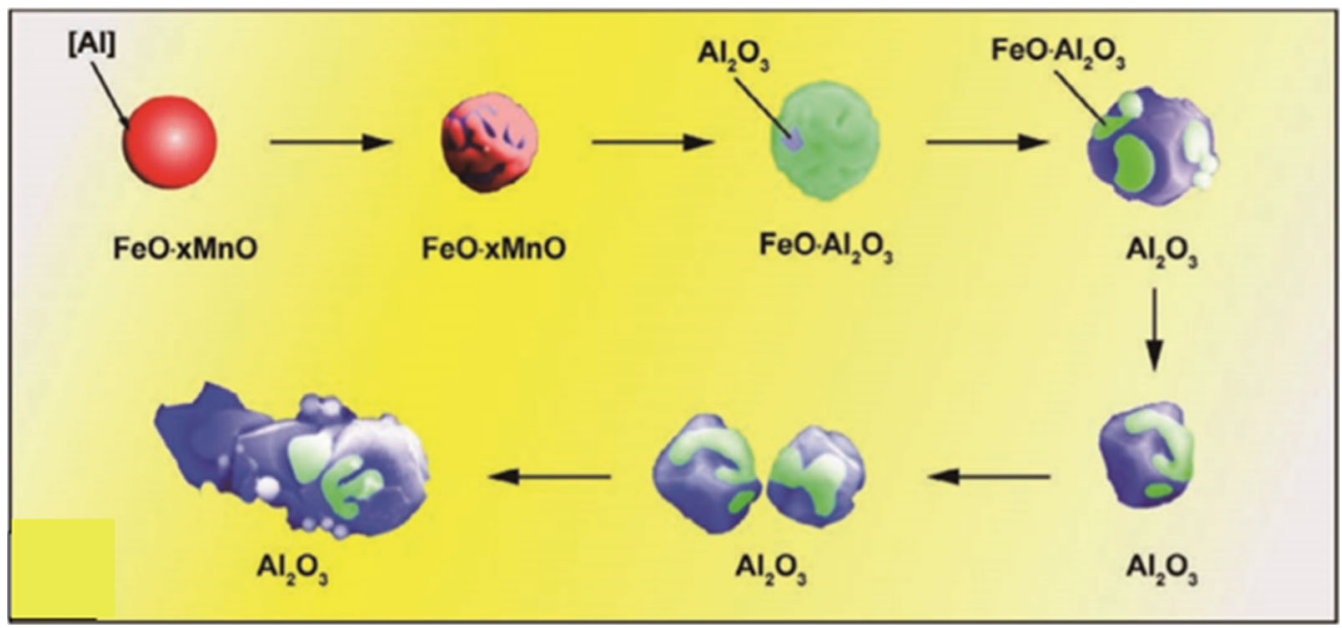

Fig. 17-Transformation mechanisms of $\mathrm{FeO} \cdot x \mathrm{MnO}$ inclusions in an Al-killed ladle refining process. Reprinted with permission from Ref. [89]. 


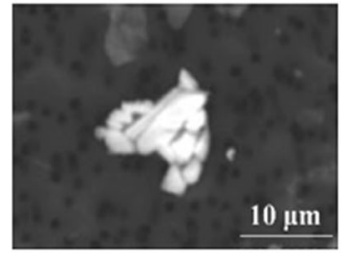

REM-Si-Mn-O (1-26 $\mu \mathrm{m})$

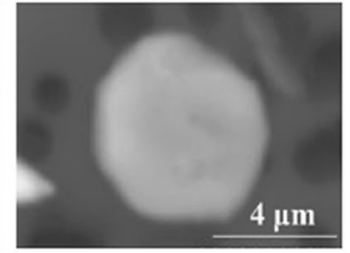

$\mathrm{Al}-\mathrm{O}(2-15 \mu \mathrm{m})$

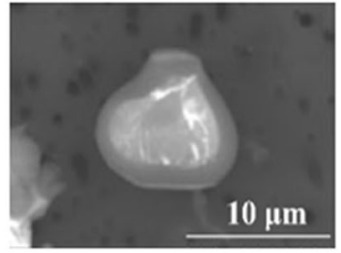

$\mathrm{Si}-\mathrm{Ca}-\mathrm{Mg}-\mathrm{O}(6-12 \mu \mathrm{m})$

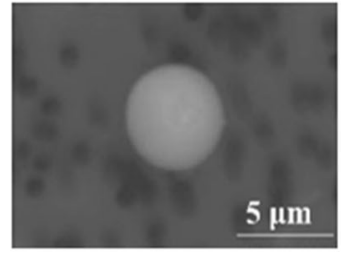

$\mathrm{Si}-\mathrm{Mn}-\mathrm{O}(1-8 \mu \mathrm{m})$

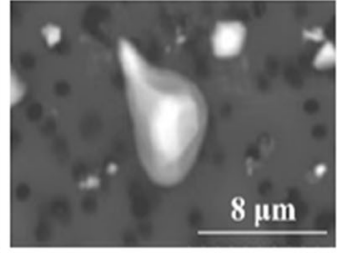

$\mathrm{Mn}-\mathrm{Si}-\mathrm{Fe}-(\mathrm{O})(3-16 \mu \mathrm{m})$

Fig. 18 - Classification of typical inclusions found in SiMn alloys. Reprinted with permission from Ref. [18].

From the discussions above, we can conclude that the most common inclusion types in $\mathrm{FeSi}$ alloys are $\mathrm{Ca}-\mathrm{Si}-\mathrm{Al}-\mathrm{Mg}-\mathrm{O}$ compounds, $\mathrm{SiC}, \mathrm{Al}_{2} \mathrm{O}_{3}$ and $\mathrm{SiO}_{2}$. The inclusions in $\mathrm{FeSi}$ alloys that might be harmful for the steel cleanliness are REM oxides, $\mathrm{Al}_{2} \mathrm{O}_{3}$ and big size $\mathrm{SiO}_{2}$ inclusions. The primary oxide inclusions that are formed during a Si-deoxidation are pure $\mathrm{SiO}_{2}$ inclusions and iron-oxide inclusions surrounded by a $\mathrm{SiO}_{2}$ layer. These inclusions can further act as heterogeneous nucleation sites for secondary inclusions in subsequent processes. Most of the research has focused on the effect of $\mathrm{Al}$ and $\mathrm{Ca}$ as well as the purity of $\mathrm{FeSi}$ on the steel cleanliness, while few studies have reported results on the behaviour of existing inclusions from $\mathrm{FeSi}$ alloys in steel after the addition of FeSi to steel melts. In Si-killed steel, the low $\mathrm{Al}$ and $\mathrm{Ca}$ containing $\mathrm{FeSi}$ alloy is recommended to avoid the formation of $\mathrm{Al}_{2} \mathrm{O}_{3}$ and $\mathrm{CaO}$ in inclusions. In some cases, even the small amount of $\mathrm{Al}$ that is present in $\mathrm{FeSi}$ alloys can be detrimental,${ }^{[86]}$ for such steels, a special grade of FeSi with lower levels of Al should be used. While in Al-killed steel, FeSi containing $\mathrm{Ca}$ is recommended for the alloying process.

\section{FeMn alloys}

HCFeMn alloys are commercially produced by the carbothermic reduction of manganese ores, primarily in electric submerged arc furnaces. The commercial production processes of LCFeMn alloys include either the silicothermic reduction of involving the reaction between silicon in crude SiMn alloy and manganese ore or through decarburization of high carbon FeMn alloy by blowing oxygen. ${ }^{[10]}$

According to the results of Pande et al.' ${ }^{[21]}$ study, $\mathrm{SiO}_{2}$ was obtained after the dissolution of LCFeMn alloys and $\mathrm{MnO}-\mathrm{SiO}_{2}-\mathrm{MnS}$ inclusions were found in the matrix of the alloys. These results indicated that the $\mathrm{MnO}-\mathrm{MnS}$ inclusions were dissolved in an $\mathrm{HCl}$ acid solution. In addition, Sjökvist et al. ${ }^{[7]}$ reported that the majority of inclusions in $\mathrm{MCFeMn}$ alloys were nearly pure dendritic and rhombic $\mathrm{MnO}$ inclusions, while the remaining ones were $\mathrm{MnS}$ and $\mathrm{MnO}-\mathrm{SiO}_{2}-\mathrm{MnS}$ inclusions. Furthermore, the volume fraction of inclusions was found to have an inverse relationship with the carbon content. In addition, silicon also can affect the inclusion composition. The results showed that both dendritic and rhombic oxides might form when the Si contents were below 0.3 mass pct. Furthermore, only rhombic oxide inclusions may form when the $\mathrm{Si}$ contents were between 0.3 and 0.5 mass pct. Finally, complex compounds containing $\mathrm{Mn}, \mathrm{Si}, \mathrm{S}$ and $\mathrm{O}$ were formed at $\mathrm{Si}$ contents above 0.5 mass pet.

$\mathrm{MnS}$ inclusions are common sulphides found in FeMn alloys, but Sharapova ${ }^{[71]}$ reported that TiS-MnS compounds also existed. Moreover, they found TiS-TiC and $\operatorname{Ti}(\mathrm{C}, \mathrm{N})$ inclusions. Han et al. ${ }^{[19]}$ reported that $\mathrm{CaO}-\mathrm{MnO}$ inclusions, as well as long strips or square $2 \mathrm{MnO} \cdot \mathrm{SiO}_{2}$, inclusions were found in MCFeMn alloys. Besides, long finger-like $\mathrm{SiO}_{2}$ inclusions and $\mathrm{TiN}$ with quartz crystals were reported in LCFeMn alloys by Vorob'e ${ }^{[54]}$ The typical inclusions found in FeMn alloys are shown in Figure 14.

The formation and transformation of Mn-containing inclusions were closely related to the yield of $\mathrm{Mn}$ in the melt. Not many studies have mentioned the effect of FeMn additions on steel cleanliness. This might be attributed to the fact that FeMn alloys are usually added at an early stage of the ladle refining and the impurities from these alloys do not have a large effect on the final steel cleanliness. Some of the previous works related to this point are summarized below.

Sjökvist and Jönsson ${ }^{[8]}$ made laboratory experiments to investigate the effect of FeMn additions on the inclusion characteristics in steel. The results showed that normally refined LCFeMn alloys not only contained more $\mathrm{MnO}$ inclusions but also led to an increased amount of inclusions in the steel. In addition, a low oxygen FeMn (400 ppm O) alloy resulted in a lower inclusion content $(0.014$ area pct) in the steel compared to a standard alloy. A similar conclusion was reported by Han et al. ${ }^{[19]}$ They used the bulk sample electrolysis method to study the change of macro-inclusions in samples taken from the process route of pipeline steels when an MCFeMn alloy was added. They showed that the amount of inclusions increased from $10.87 \mathrm{mg} / 10 \mathrm{~kg}$ to $32.27 \mathrm{mg} / 10 \mathrm{~kg}$ during the ladle furnace treatment. Therefore, they concluded that refined LC(MC)FeMn alloys with total oxygen contents less than 0.04 mass pct were recommended to be used to adjust the composition during the refining process.

Sjökvist and Jönsson ${ }^{[8]}$ also made industrial experiments to establish the influence of four different refined FeMn additions on the inclusion characteristics in bearing steels. ${ }^{[4]}$ They reported that the addition of FeMn alloys caused an increase of the inclusion contents up to 9 minutes from the time of addition, after which the inclusion contents were stabilised after vacuum degassing to a similar level for all FeMn grades. The 


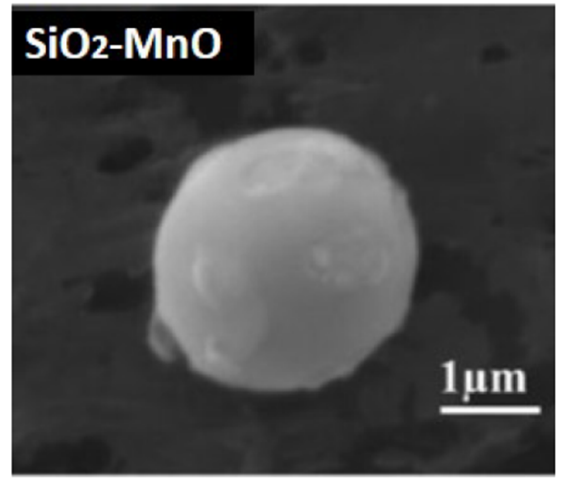

(a)

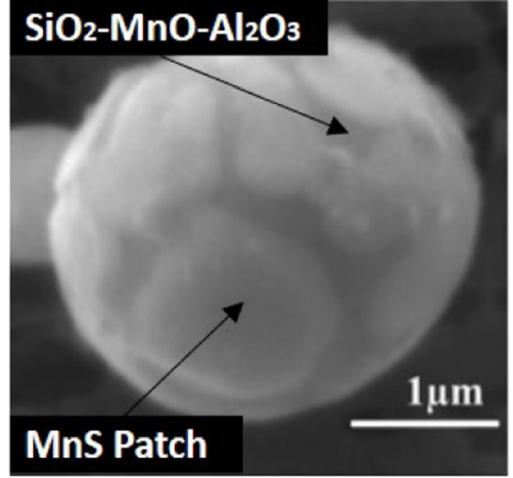

(b)

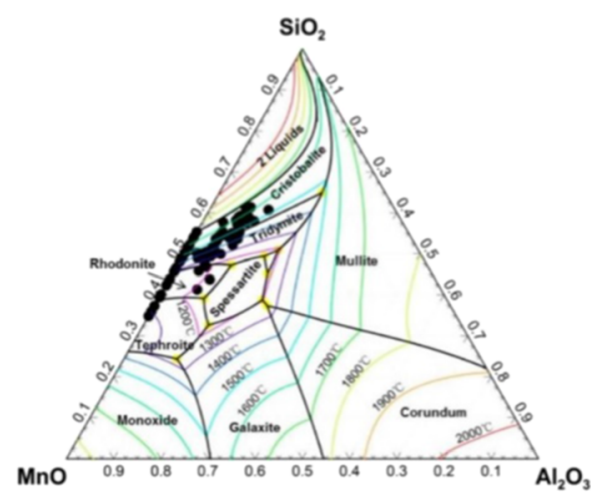

(c)

Fig. 19-Typical inclusions extracted from steel samples after a $\mathrm{Si} / \mathrm{Mn}$ addition (a) $\mathrm{SiO}_{2}-\mathrm{MnO}$, (b) $\mathrm{SiO}_{2}-\mathrm{MnO}_{-}-\mathrm{Al}_{2} \mathrm{O}_{3}-\mathrm{MnS}$ and (c) inclusion distributions in a $\mathrm{SiO}_{2}-\mathrm{MnO}-\mathrm{Al}_{2} \mathrm{O}_{3}$ phase diagram. Reprinted with permission from Ref. [104].

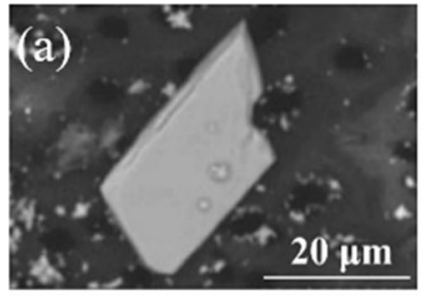

$\mathrm{Ti}-\mathrm{Fe}(6-25 \mu \mathrm{m})$

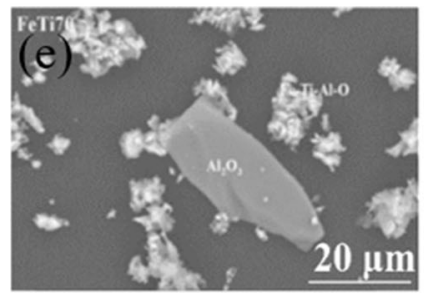

Al-O

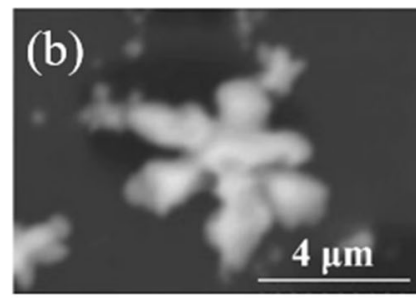

$\mathrm{Ti}-\mathrm{Fe}(1-8 \mu \mathrm{m})$

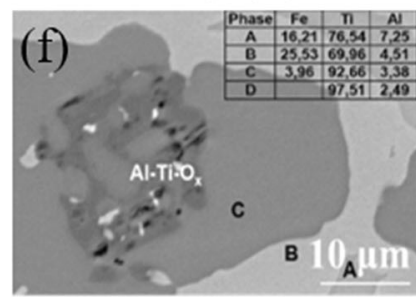

Al-Ti-O

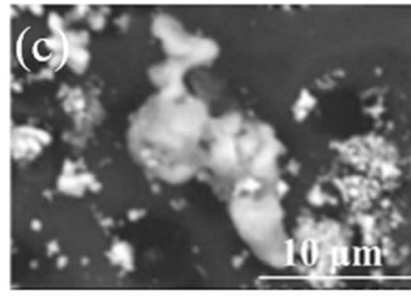

Ti-Fe-Al-O (3-15 بm)

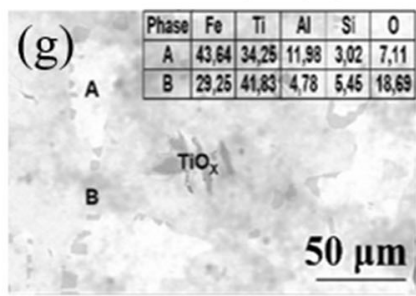

Ti-O

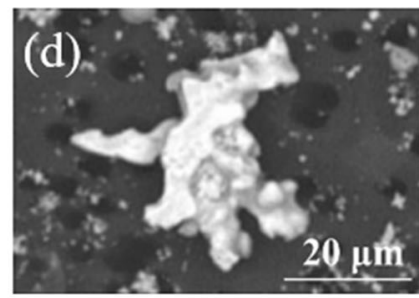

REM-Si-Cr-Al-O (1-21 $\mu \mathrm{m})$

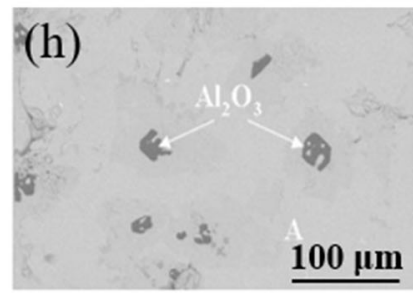

Al-O

Fig. 20-Classification of inclusions in FeTi alloys, (a) through (d) reprinted with permission from Ref. [18], (e) through (g) reprinted with permission from Ref. [21], and $(h)$ reprinted with permission from Ref. [61].

$\mathrm{MnO}$ and $\mathrm{MnS}$ inclusions were inherited from FeMn to the liquid steel during alloying. These results were in good agreement with another paper, where pure $\mathrm{MnO}$ inclusions remained in steel as their melting point (2117 $\mathrm{K}, 1844{ }^{\circ} \mathrm{C}$ ) was above the steelmaking temperature $\left(1873 \mathrm{~K}, 1600{ }^{\circ} \mathrm{C}\right)$, and the floatation and removal rates were low. ${ }^{[74]}$ Moreover, similar inclusion characteristics in the final samples were found irrespective of the FeMn grades being used, which indicated that FeMn grades only have a temporary influence on the inclusion characteristics in steel during ladle refining. However, it is entirely possible that this influence is important in some cases, such as when an LCFeMn alloy is added as a final adjustment immediately before casting.

Thapliyal et al. ${ }^{[53]}$ investigated the inclusion evolutions after FeMn additions based on a laboratory experiment. The results showed that most of the oxide inclusions were spherical $\mathrm{MnO}-\mathrm{SiO}_{2}$ based inclusions containing some $\mathrm{Al}_{2} \mathrm{O}_{3}$ and sulfur-rich inclusions, which had either pure $\mathrm{MnS}$ inclusions or $\mathrm{MnS}$ as a predominant phase in the oxide inclusions. Another similar study was made by the same authors. ${ }^{[48]}$ They reported that $\mathrm{FeO}-\mathrm{MnO}$ and $\mathrm{MnO}-\mathrm{SiO}_{2}$ inclusions were found after a FeMn dissolution in the steel. In addition, the solid solution of $\mathrm{FeO}-\mathrm{MnO}$ was precipitated inside the liquid $\mathrm{FeO}-\mathrm{MnO}-\mathrm{SiO}_{2}$ inclusions, due to the increased $\mathrm{MnO}$ content after a FeMn addition. Specifically, the local Mn content can reach a level of above 7 mass pct. The typical inclusions and their formation mechanisms are shown in Figure 15.

Detailed information on the $\mathrm{FeO}-\mathrm{MnO}$ inclusion formation after MCFeMn additions during the $\mathrm{RH}$ refining was reported by Li et al. ${ }^{[88]}$ They showed that spherical $3 \mathrm{FeO} \cdot \mathrm{MnO}$ inclusions that were formed before the melt reached the solidification temperature could later act as heterogeneous nucleation sites for $\mathrm{FeO} \cdot z \mathrm{MnO}$ shelled inclusions. Figure 16 represents the different $\mathrm{Fe} / \mathrm{Mn}$ ratios in the core and shell of the inclusions, which have different solidification temperatures, and their evolution mechanism. These inclusion 


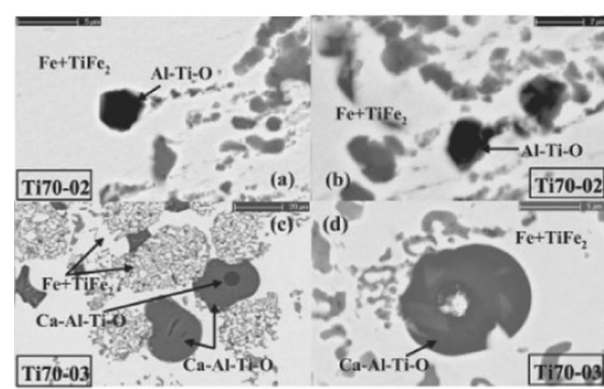

(a)

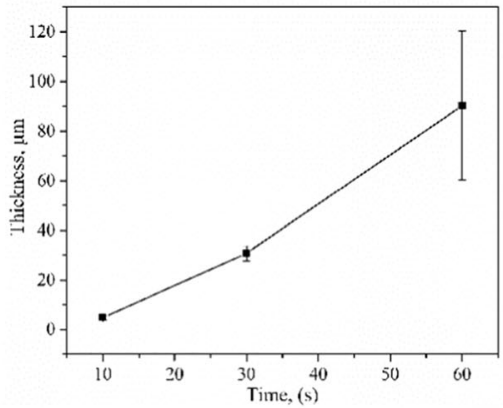

(b)

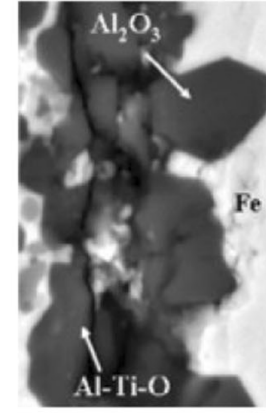

(c)

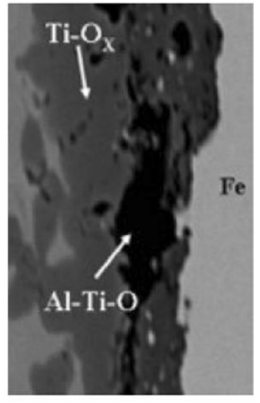

(d)

Fig. 21-The micrographs of the inclusions in FeTi70-2 (20 seconds contact time) and FeTi70-3 (30 seconds contact time) (a) and the growth of the thickness of an oxide layer $(b)$ and the micrographs of the oxide layer in FeTi35-1 (10 seconds contact time) $(c)$, and FeTi35-2 (20 seconds contact time (d). Reprinted with permission from Ref. [61].

types were found to have no solid interface and they were easier to transform and eliminated at the beginning of the degassing stage.

The characteristics of manganese-containing inclusions during the Al-killed process in interstitial-free steels were studied by Wang et al. ${ }^{[89]}$ They found that spherical $\mathrm{FeO} \cdot x \mathrm{MnO}$ inclusions with sizes below $5 \mu \mathrm{m}$ existed after an MCFeMn alloy addition. However, almost all these $\mathrm{FeO} \cdot x \mathrm{MnO}$ inclusions were transformed to $\mathrm{Al}_{2} \mathrm{O}_{3}$ inclusions after $\mathrm{Al}$ was added to the steel melt. This took place in the following order: spherical $\mathrm{FeO} \cdot x \mathrm{MnO} \rightarrow$ spherical $\mathrm{FeO} \cdot x \mathrm{MnO}$ with coarse surface $\rightarrow$ polygonal $\mathrm{FeO} \cdot \mathrm{Al}_{2} \mathrm{O}_{3} \rightarrow$ polygonal $\mathrm{Al}_{2} \mathrm{O}_{3} \rightarrow$ aggregated $\mathrm{Al}_{2} \mathrm{O}_{3}$, as shown in Figure 17. This showed that inclusions from FeMn only existed during a short time of the Al-killed ladle treatment process.

To summarize, it may be concluded that $\mathrm{MnO}, \mathrm{MnS}$ and $\mathrm{MnO}-\mathrm{SiO}_{2}-\mathrm{MnS}$ inclusions which are present in $\mathrm{FeMn}$ alloys may be inherited by the steel, but they have little influence on the steel quality. The primary oxide for $\mathrm{Mn}$-deoxidation is $\mathrm{MnO}$, which generally form a solid solution with $\mathrm{FeO}$ and is observed as $\mathrm{Fe}_{\mathrm{x}} \mathrm{Mn}_{1-\mathrm{x}} \mathrm{O}$ inclusions. These inclusions only have a temporary influence on the content and composition of inclusions in the steel, since they can easily float up into the slag or be reduced by other elements. Overall, the quality of FeMn alloys only has to be considered when they are added at a final stage of the ladle refining. However, the effect of TiS and $\operatorname{Ti}(\mathrm{C}, \mathrm{N})$ from FeMn alloys on the steel cleanliness is still not so clear.

\section{SiMn alloys}

The use of SiMn alloys is expected to advance at a faster rate than HCFeMn consumption. SiMn alloys are also produced by the carbothermic reduction of raw materials in electric submerged arc furnaces of the same type as used for the production of HCFeMn. The difference is that higher process temperatures are needed to attain the wanted $\mathrm{Si}$ content in the SiMn process due to high melting point of tapping slag, of which $\mathrm{MnO}$ content is very low. ${ }^{[10]}$

The typical inclusions found in these alloys using the EE method are shown in Figure 18. ${ }^{[18]}$ The majority of them are REM oxides containing some amounts of $\mathrm{Si}$, $\mathrm{Mn}$, which accounted for 56 pct of the total inclusion content. These were followed by 28 pct $\mathrm{Mn}-\mathrm{Si}$ intermetallic phases, 14 pct silicon oxides containing some $\mathrm{Ca}$ and $\mathrm{Mg}$, and a small amount of pure $\mathrm{Al}_{2} \mathrm{O}_{3}$ inclusions. The $\mathrm{Al}_{2} \mathrm{O}_{3}$ inclusions and $\mathrm{REM}$ oxides probably remain solid and form clusters when the alloy is added to steel. This, in turn, would cause decreased mechanical properties in the final product.

In addition, clusters of titanium carbide (TiC) exist, which can lead to an increased titanium content in the deoxidation product after the SiMn addition to the steel. A possible behaviour of $\mathrm{TiC}$ inclusions is that they might dissolve in the steel and allow titanium to precipitate as $\mathrm{TiO}_{x}$ in the inclusions or that they remain insoluble and act as a core for oxide inclusions. However, whether $\mathrm{TiC}$ is generally common in this alloy or not is not clearly known. Further investigations of inclusions in different grades of SiMn alloys are necessary to carry out to obtain this lacking information.

For silicon killed steel, manganese additions are made along with silicon to improve the deoxidation process as well as to form liquid manganese-silicate inclusions instead of solid silica inclusions. ${ }^{[90,91]}$ Another advantage of using an $\mathrm{Mn}-\mathrm{Si}$ combined deoxidation is that the remaining $\mathrm{MnO}-\mathrm{SiO}_{2}$ based inclusions are more uniformly dispersed in solidified steel, which can improve the steel performance. ${ }^{[92,93]}$

Numerous studies have focused on the inclusion evolution in $\mathrm{Si}-\mathrm{Mn}$ killed steels. ${ }^{[50,79,94-98]}$ In some cases, a SiMn alloy was added in steel together with $\mathrm{FeMn}^{[99,100]}$ and FeSi. ${ }^{[101,102]}$ Here, the MnO$\mathrm{SiO}_{2}-\mathrm{Al}_{2} \mathrm{O}_{3}$ system is one of the most important systems for the study of inclusions in these steels, where the $\mathrm{MnO}$ and $\mathrm{SiO}_{2}$ contents in the inclusions can be controlled by the $\mathrm{Mn} / \mathrm{Si}$ ratio of the steel. ${ }^{[103]} \mathrm{Yin}$ et al. ${ }^{[104]}$ studied the inclusions in $17 \mathrm{Cr}-9 \mathrm{Ni}$ austenitic stainless steels by using electrolytic extraction. The inclusions after SiMn deoxidation were manganese silicates and inclusions containing both $\mathrm{MnO}-$ $\mathrm{SiO}_{2}-\mathrm{Al}_{2} \mathrm{O}_{3}$ and $\mathrm{MnS}$. Their compositions were concentrated close to the region which is liquid at the steelmaking temperature, as shown in Figure 19. Yan et $a l .{ }^{[93]}$ investigated the interactions when a FeMnSi alloy was added to the liquid $\mathrm{Fe}$ based on quenched 


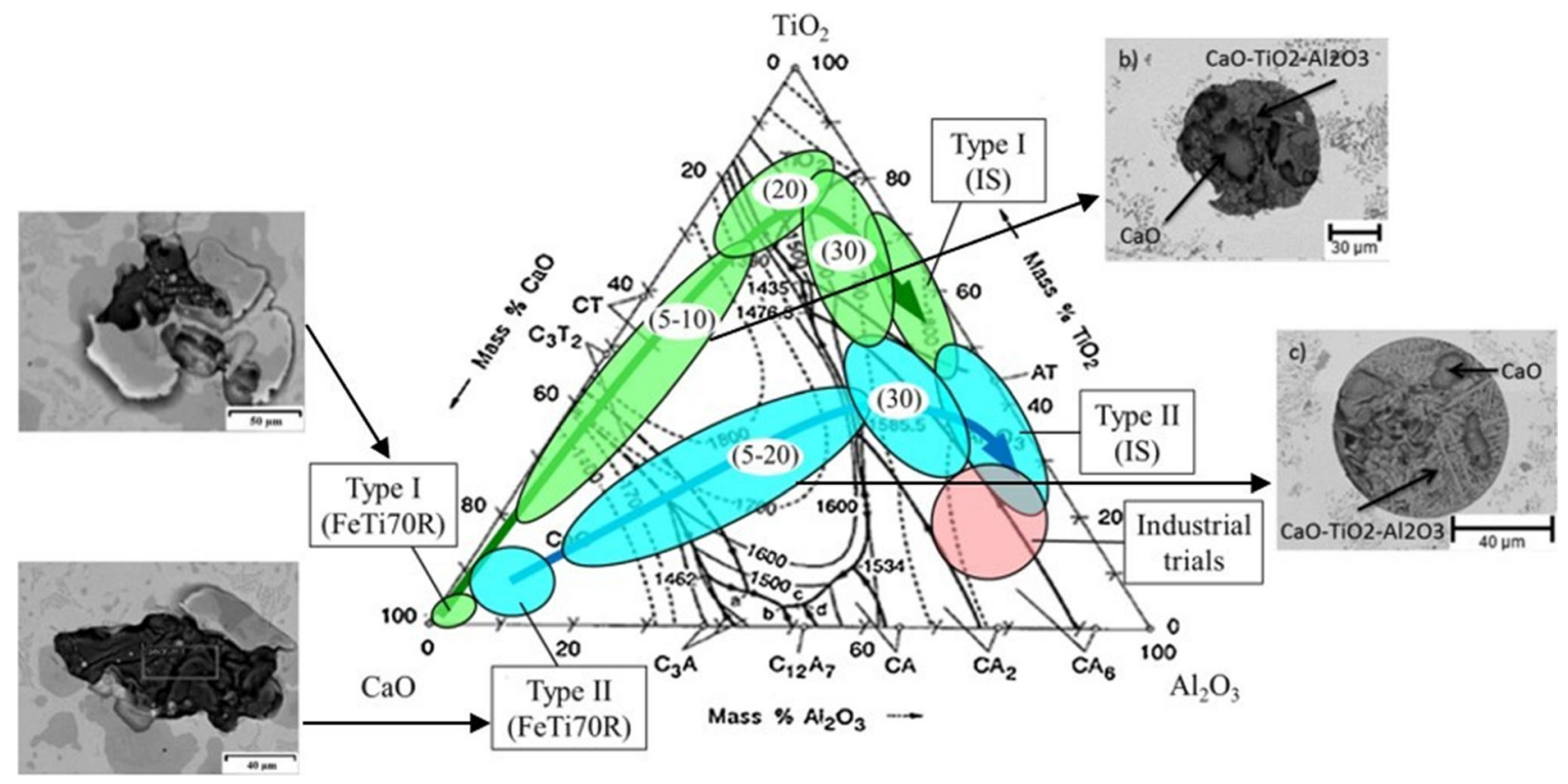

Fig. 22 - Compositions of Type I and Type II inclusions in samples from a FeTi70R alloy, based on laboratory experiments and industrial trials. Reprinted with permission from Ref. [20].

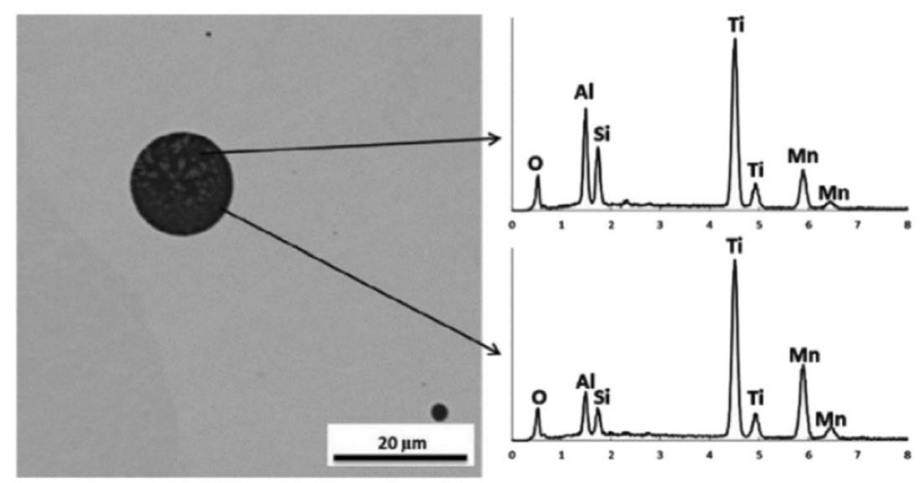

(a)

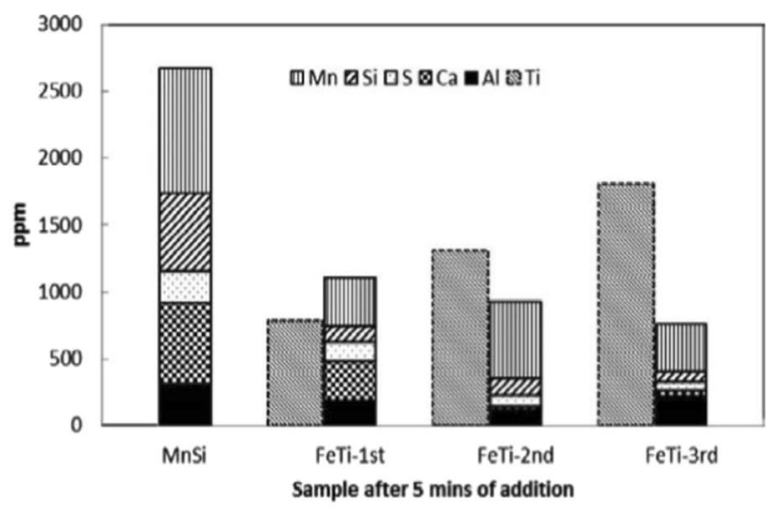

(b)

Fig. 23-Typical Ti-Mn-Al-Si-O oxide inclusions with a Ti-rich phase as precipitates, observed 5 minutes after the first FeTi addition $(a)$ and the amount of each element in the inclusions $(b)$. Reprinted with permission from Ref. [53].

diffusion samples. They reported the formation mechanism of $(\mathrm{Mn}, \mathrm{Si}) \mathrm{O}$ inclusions during the early stages of the deoxidation process. These results contribute to improving the knowledge of how a successful SiMn combined alloy addition/deoxidation should be done during ladle refining.

The behaviour of REM oxides and TiC from SiMn alloys in steel should be studied further. The use of SiMn is expected to advance at a faster rate than the FeMn consumption. In addition, deoxidation with $\mathrm{SiMn}$ is more effective compared to when using $\mathrm{FeSi}$, as the former has a high density and can penetrate sufficiently deep into molten steel bath compared to the latter. ${ }^{[105]}$ A SiMn addition results in less impurities such as phosphorous, nitrogen, aluminium to steel compared to when using a mixture of $\mathrm{HCFeMn}$ and FeSi75. ${ }^{[10]}$
From an economic perspective, in the production of steel when the max carbon content is 0.04 mass pct, $\mathrm{Si}-\mathrm{Mn}$ is selected because it is cheaper compared to a low carbon FeMn alloy. ${ }^{[49]}$ Therefore, the use of SiMn instead of FeMn and FeSi results in both technical advantages and production cost reductions.

\section{FeTi alloys}

Usually, reduction of titanium from ilmenite ( $\mathrm{FeO} \cdot-$ $\left.\mathrm{TiO}_{2}\right)$ and rutile $\left(\mathrm{TiO}_{2}\right)$ by carbon proceeds first with the reduction of iron oxides and later with the reduction of titanium. However, such a process usually leads to the formation of $\mathrm{Fe}-\mathrm{Ti}-\mathrm{C}$ alloys containing high $\mathrm{C}$ content, which has limited application in steelmaking. The most common method for FeTi processing is produced by the aluminothermic reduction of ilmenite and rutile. In 


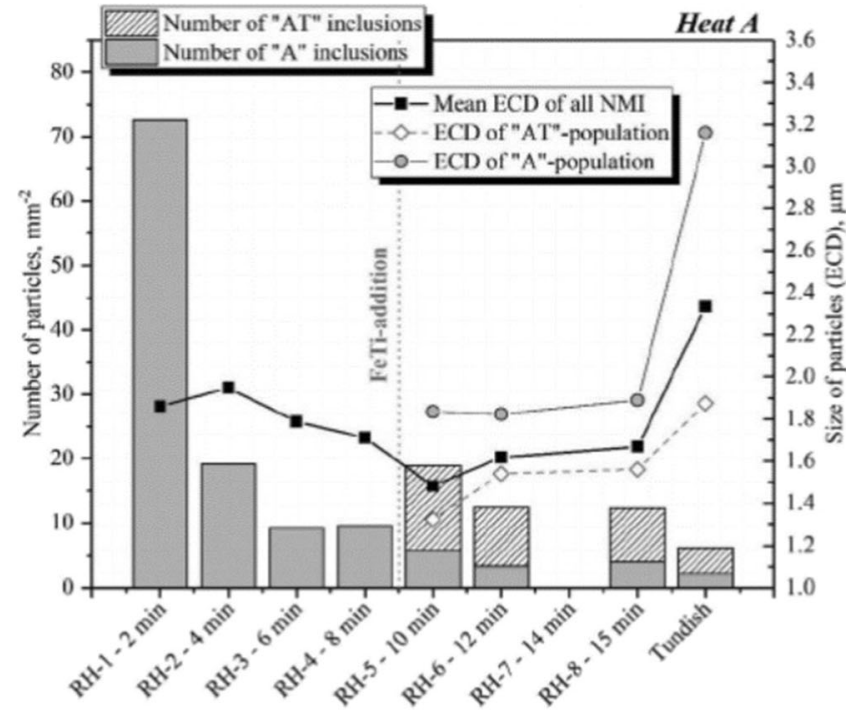

(a)

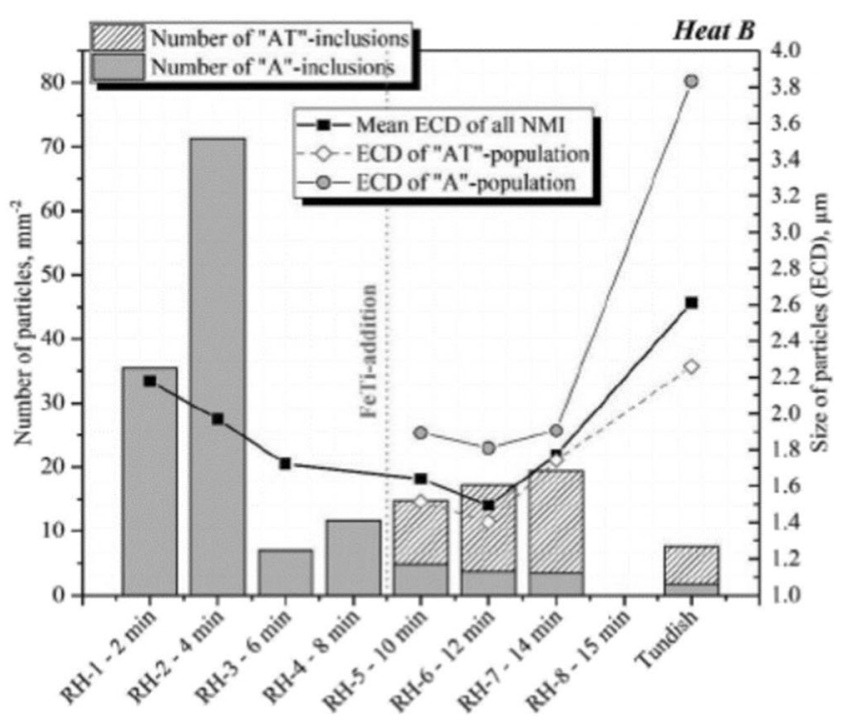

(b)

Fig. 24-Numbers and sizes of alumina particles with ("AT") and without Ti ("A") in samples of heat A (a) and B (b) during secondary refining and in a tundish. Reprinted with permission from Ref. [110].

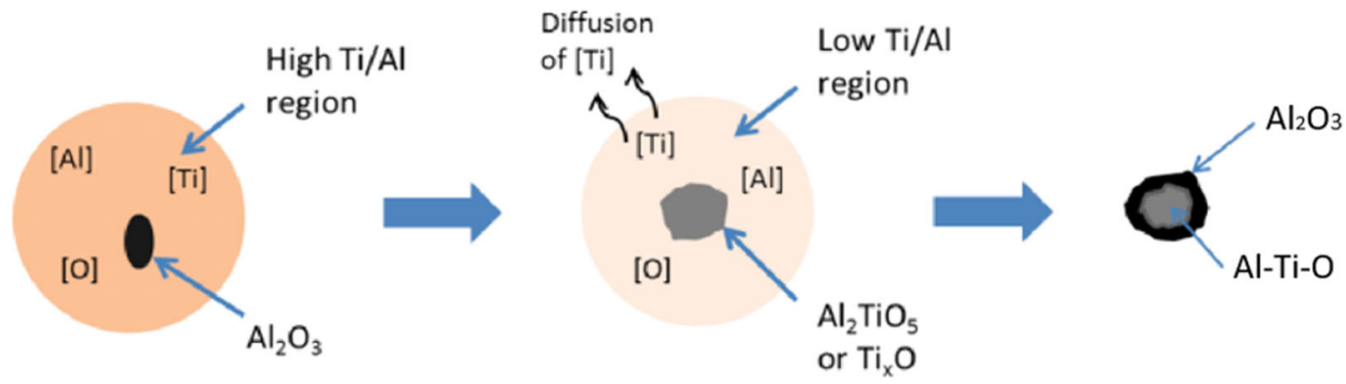

Fig. 25-Schematic illustration of the formation mechanism of heterogenous Al-Ti-O inclusions. Reprinted from Ref. [111].

addition, some high grades FeTi70 is also manufactured by alloying titanium sponge with iron. The phase composition in the alloy depends on the content of titanium and impurities in $\mathrm{FeTi}^{[9]}$

The typical inclusions in FeTi alloys observed by different researchers are shown in Figure 20. The inclusions in $\mathrm{FeTi}$ alloys were investigated using the EE method by Bi et al. ${ }^{[18]}$ They found that Ti-Fe intermetallic phases were the most common ones and they accounted for 84 pct of the total inclusion content. However, these phases are assumed to melt and dissolve after the addition to the liquid steel. The remaining inclusion types were $\mathrm{Ti}-(\mathrm{Fe}-\mathrm{Al}-\mathrm{O})$ and REM (Ce, La, $\mathrm{Pr}, \mathrm{Nd}$ ) oxides. REM oxides were reported to easily form clusters, which may cause nozzle clogging during casting of steel. ${ }^{[106,107]}$

Pande et al. ${ }^{[11,61]}$ studied the inclusions in FeTi35 (70) alloys using the acid-3D method followed by microstructure determinations. They found $\mathrm{Al}_{2} \mathrm{O}_{3}$ and faceted $\mathrm{Al}-\mathrm{Ti}-\mathrm{O}, \mathrm{Fe}-\mathrm{Al}-\mathrm{Ti}-\mathrm{O}$ inclusions in FeTi70 alloys and irregular $\mathrm{Si} / \mathrm{SiO}_{2}$ and $\mathrm{Al}-\mathrm{Ti}-\mathrm{O}, \mathrm{Al}_{2} \mathrm{O}_{3}$ and $\mathrm{TiO}_{x}$ inclusions in FeTi35 alloys. The weight percentage of the extracted inclusions in FeTi35 alloys reached 9 pct, which was much higher than that for FeTi70 alloys
( 1 to $1.5 \mathrm{pct}$ ). This was due to the presence of a large amount of silicon/silica in the FeTi35 alloys. Similarly, Kaushik et al. ${ }^{[72]}$ reported that $\mathrm{Al}_{2} \mathrm{O}_{3}$ and $\mathrm{TiN}, \mathrm{Al}_{4} \mathrm{TiO}_{8}$ inclusions were observed in FeTi70 alloys. Moreover, $\mathrm{Al}_{2} \mathrm{O}_{3}$ and $\mathrm{Fe}-\mathrm{Ti}-\mathrm{Al}-\mathrm{O}$ inclusions were found by Gasik et al. ${ }^{[73]}$

Kellner et al. ${ }^{[20]}$ reported that the inclusions in a FeTi70R alloy consisted of almost pure $\mathrm{CaO}$ (96 mass pct), complex oxides having a high $\mathrm{CaO}$ content (77 mass pet) and containing 10 mass pet $\mathrm{SiO}_{2}-8$ mass pet $\mathrm{TiO}_{2}$, and complex oxides having a high $\mathrm{SiO}_{2}$ content (66 mass pet) and containing 21 mass pet $\mathrm{CaO}-10$ mass pct $\mathrm{TiO}_{2}$. Moreover, their sizes can reach $260 \mu \mathrm{m}$ and they have melting points higher than the steel melt temperature. These inclusions are quite different in comparison to the commonly reported inclusion found in the FeTi alloys. The different processing routes employed for the manufacture of these ferroalloy grades can be one reason for the different inclusion types found in the FeTi alloys. In addition, the different raw materials being used in the different manufacturing methods can result in quite different inclusion types in these alloys. 


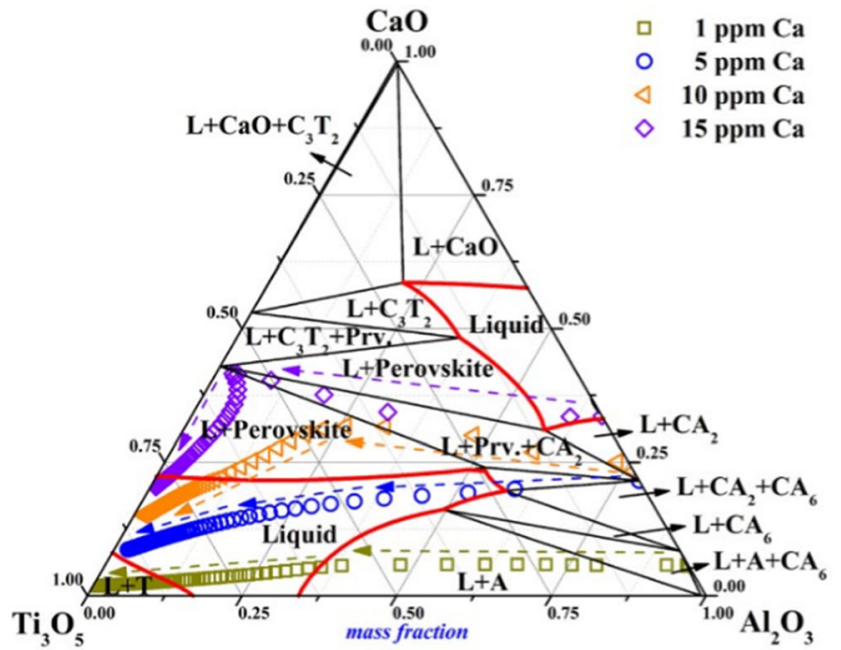

(a)

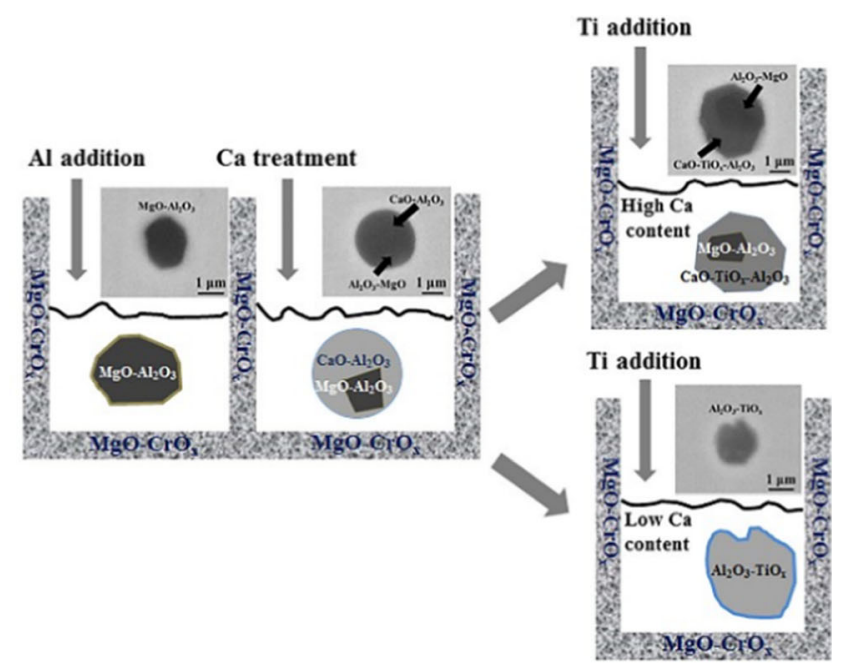

(b)

Fig. 26-Composition evolution of inclusions in $\mathrm{CaO}-\mathrm{Al}_{2} \mathrm{O}_{3}-\mathrm{Ti}_{3} \mathrm{O}_{5}$ phase diagrams during the titanium addition process at different $\mathrm{Ca}$ contents (a) and the evolution mechanism of the inclusions in Ti-bearing steels having a calcium treatment $(b)$. Reprinted from Ref. [127].

Several researchers have studied the influence of FeTi additions on the inclusion characteristics in the steel melt. Pande et al. ${ }^{[61]}$ investigated the dissolution behaviour and the mechanisms of the inclusion formation between a FeTi alloy and liquid iron using the liquid metal suction method. A significant supersaturation occurred at the periphery of the dissolving/ melting FeTi surface, which resulted in the formation of $\mathrm{Al}-\mathrm{Ti}-\mathrm{O}$ and $\mathrm{Ca}-\mathrm{Al}-\mathrm{Ti}-\mathrm{O}$ inclusions. The inclusions observed in the sample of a FeTi70-2 alloy (20 s contact time) and a FeTi70-3 alloy (30 s contact time) are shown in Figure 21(a). The formation of Al-Ti-O inclusions can occur due to the reactions involving dissolved $\mathrm{Ti}, \mathrm{Al}$ and $\mathrm{O}$. The $\mathrm{Ca}-\mathrm{Al}-\mathrm{Ti}-\mathrm{O}$ inclusion were found to be formed by the reaction between $\mathrm{Al}-\mathrm{Ti}-\mathrm{O}$ or dissolved $\mathrm{Ti}$ and already existing $\mathrm{Ca}-\mathrm{Al}-\mathrm{O}$ inclusions. Therefore, it is clear that impurities such as $\mathrm{Al}$ and $\mathrm{Ca}$ present in FeTi70 alloys contribute to an inclusion formation in the steel.

In the FeTi35 alloy, the impurities were $\mathrm{Al}, \mathrm{Al}_{2} \mathrm{O}_{3}$ and unreduced $\mathrm{TiO}_{x}$ inclusions. After being in contact with liquid $\mathrm{Fe}$, an oxide layer (mainly $\mathrm{Al}$ and $\mathrm{Ti}$ oxide) was formed between the FeTi35 alloy and liquid iron. This layer grew in thickness with an increased time, as shown in Figure 21(b). A possible mechanism of the oxide layer formation was that $\mathrm{Al}$ and $\mathrm{Ti}$ from FeTi35 combined with the dissolved oxygen from the liquid iron to form small alumina and Al-Ti-O inclusions, as shown in Figures 21(c) and (d). As the contact time increased, further oxidation took place on the FeTi35 side forming a continuous $\mathrm{TiO}_{\mathrm{x}}$ layer containing $\mathrm{Al}-\mathrm{Ti}-\mathrm{O}$ inclusions. It is certain that the FeTi35 addition introduces $\mathrm{Al}_{2} \mathrm{O}_{3}$ and $\mathrm{Al}-\mathrm{Ti}-\mathrm{O}$ inclusions to the liquid steel, which are consistent with the inclusions present in FeTi35 alloys.

In another paper by Pande et al., ${ }^{[41]}$ the influence of impurities in FeTi on the steel cleanliness in an industrial process was studied. FeTi70 (2 to 3 mass pct soluble $\mathrm{Al}$ and 0.1 to 0.2 mass pet total oxygen) and
FeTi35 alloys ( 5 to 6 mass pet soluble $\mathrm{Al}$ and $0.4-1$ mass pct total oxygen) were added to liquid steel. The results showed that the number of generated inclusions was higher with a FeTi35 addition compared to a FeTi70 addition, which can be attributed to the presence of a large amount of $\mathrm{Al}_{2} \mathrm{O}_{3}$ (1 to 2 mass pct insoluble $\mathrm{Al}$ ) inclusions and a high oxygen content. In addition, the limited time for inclusion flotation after a FeTi35 addition also contributed to the high inclusion density. Thus, more attention should be paid to the cleanliness of FeTi alloys, since this has a direct effect on steel cleanliness.

Kellner et al. ${ }^{[20]}$ studied the evolution and behaviour of inclusions after the addition of FeTi70R alloys into the liquid iron and $\mathrm{Fe}-40 \mathrm{Ni}-20 \mathrm{Cr}$ steel, based on laboratory experiments and industrial trials. They showed that after the addition of a FeTi70 alloy to steel, a liquid layer which had a higher content of Al and $\mathrm{Ti}$ in comparison to their concentrations in the bulk of the steel and the inclusions from the melted alloy piece entered this layer. The evolution of inclusions after the addition of the FeTi70R alloy is shown in Figure 22. The type I and II inclusions containing high amounts of $\mathrm{CaO}$ from the alloy were transformed into globular $\mathrm{CaO}-\mathrm{TiO}_{x}-\mathrm{Al}_{2} \mathrm{O}_{3}$ inclusions within a period of 10 to 30 seconds. In addition, the irregular type III high $\mathrm{SiO}_{2}$ contained inclusions transformed to complex globular inclusions containing mainly $\mathrm{TiO}_{x}$ and $\mathrm{Al}_{2} \mathrm{O}_{3}$ and some amounts of $\mathrm{SiO}_{2}$ and $\mathrm{CaO}$. They concluded that inclusions with sizes of less than $80 \mu \mathrm{m}$ can be present in the cast steel because a longer time is needed for floatation. Therefore, this also confirmed that the addition of FeTi alloys can directly affect steel cleanliness.

The use of FeTi after a Si-Mn deoxidation has the potential to form liquid inclusions, which are easier to separate from the steel. ${ }^{[33,108,109]}$ The modification of inclusions by FeTi70 additions in low-alloyed $\mathrm{Si}-\mathrm{Mn}$ 


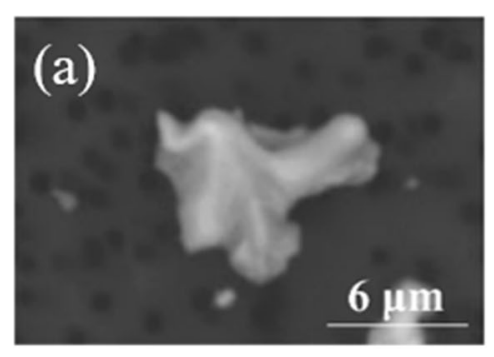

Cr-Mn-S-O (6-14 $\mu \mathrm{m})$

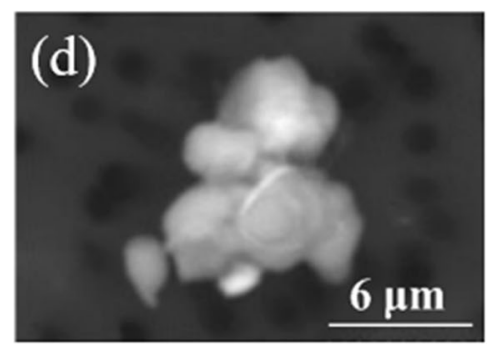

Ca-O-P $(2-26 \mu \mathrm{m})$

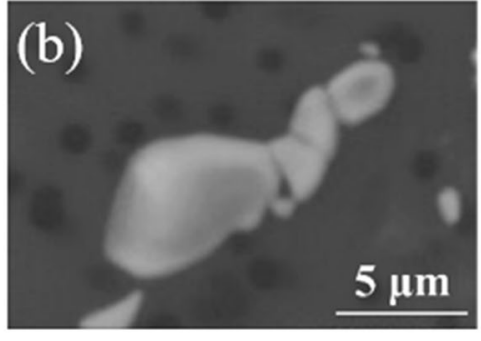

$\mathrm{Cr}-\mathrm{C}-\mathrm{N}(2-14 \mu \mathrm{m})$

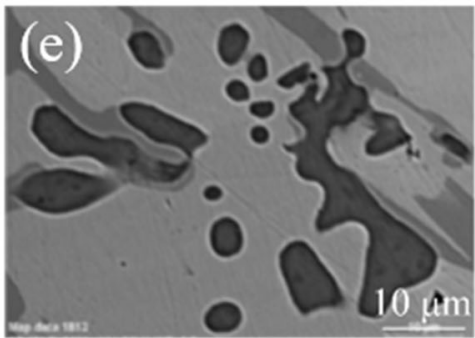

Cr-Mn-S-O $(2-15 \mu \mathrm{m})$

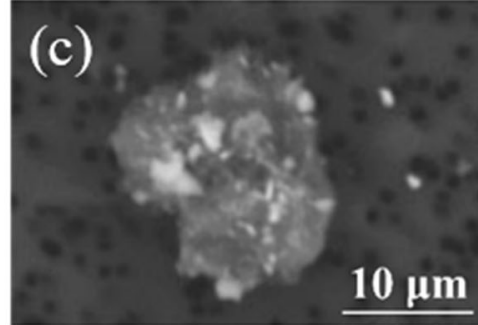

Si-Al-Ca-Mg-O (3-28 $\mu \mathrm{m})$

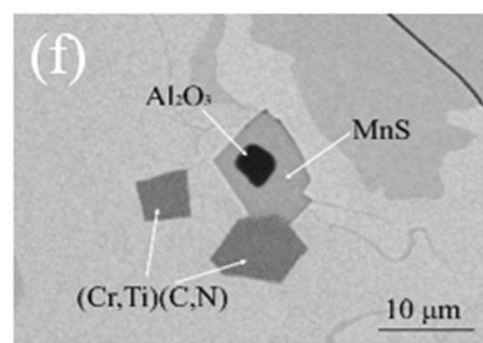

$\mathrm{Al}_{2} \mathrm{O}_{3}+(\mathrm{Cr}, \mathrm{Ti})(\mathrm{C}, \mathrm{N})+\mathrm{MnS}$

Fig. 27-Classification of typical inclusions in $\mathrm{HCFeCr}$ alloys, $(a)$ through $(e)$ reprinted with permission from Ref. [17], and $(f)$ reprinted with permission from Ref. [5].

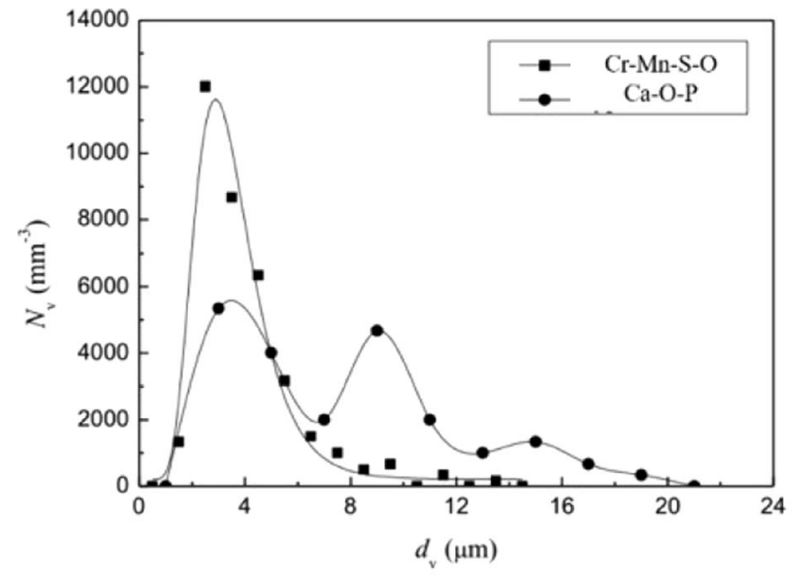

(a)

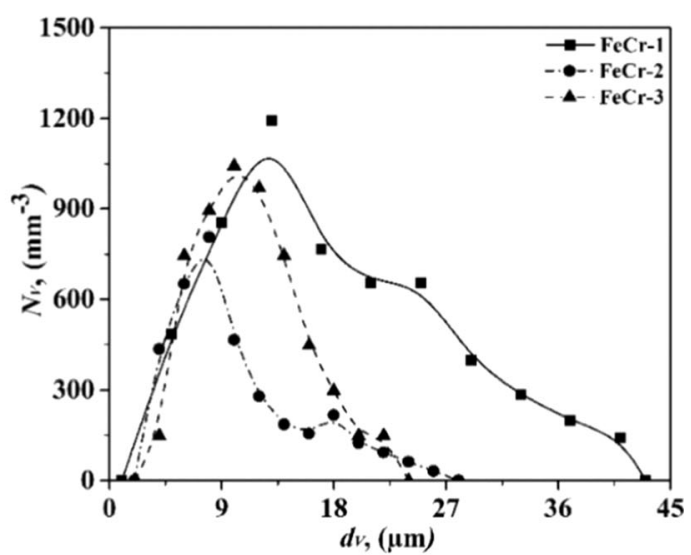

(b)

Fig. 28-Particle size distributions of $\mathrm{Cr}-\mathrm{Mn}-\mathrm{S}-\mathrm{O}$ and $\mathrm{Ca}-\mathrm{O}-\mathrm{P}$ inclusions in $\mathrm{HCFeCr}$ alloys (a), reprinted with permission from Ref. [17] and $\mathrm{Cr}-\mathrm{Mn}-\mathrm{O}$ inclusions in $\mathrm{LCFeCr}$ alloys (b), reprinted from Ref. [22], under the terms of the Creative Commons CC BY license.

killed steels was studied by Thapliyal et al. ${ }^{[53]}$ Three FeTi additions were made at 10 -minute intervals. Figure 23 showed the typical inclusions observed in the steel 5 minutes after a FeTi alloy addition was made and the amount of the different elements found in the inclusions. They found that $\mathrm{MnO}-\mathrm{SiO}_{2}$ inclusions transformed into $\mathrm{TiO}_{2}-\mathrm{MnO}-\mathrm{SiO}_{2}$ based inclusions by gaining $\mathrm{TiO}_{x}$ and losing $\mathrm{MnO}, \mathrm{SiO}_{2}$ after the addition of a FeTi alloy to steel. The average $\mathrm{Mn}$ and $\mathrm{Si}$ contents in the inclusions decreased from about 50 to 60 mass pct to about 30 mass pet and from around 35 mass pet to less than 10 mass pct, respectively. This suggested that the Si removal from the inclusions was more predominant than the Mn removal. Therefore, FeTi additions can be used to modify inclusions in
$\mathrm{Si}-\mathrm{Mn}$ killed steels and especially for low Mn steels where solid $\mathrm{SiO}_{2}$ inclusions are a major cause of concern.

It has been revealed that FeTi can act as a potential source of oxygen, which leads to the formation of new inclusions during the dissolution of the alloy. ${ }^{[21]}$ Dorrer et al. ${ }^{[110,111]}$ reported that the number of small Al-Ti-O inclusions increased significantly after the addition of a FeTi alloy during the RH treatment in ultra-low carbon steels. These inclusions were suspected to accelerate the buildup of clogging deposits during casting. The results of the inclusion assessment of two steel heats are presented in Figure 24. They indicated that FeTi alloys with low total oxygen contents were beneficial to use to improve the casting performance of steels. 


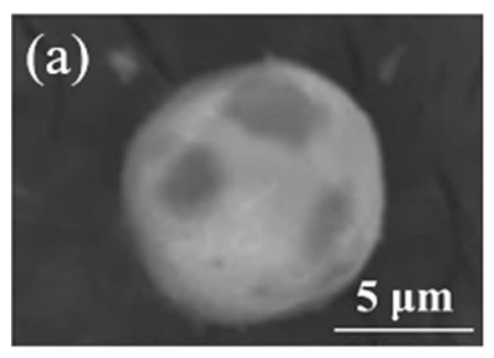

Si-Cr-Mn-O-N (2-16 بm)

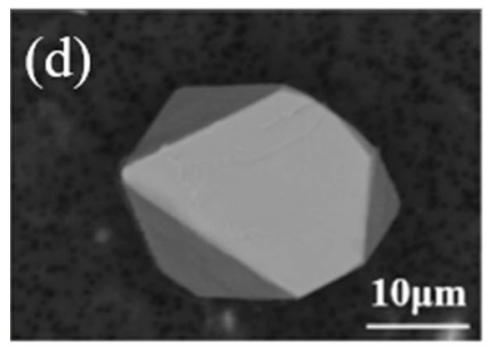

$\mathrm{Cr}-\mathrm{Mn}-\mathrm{O}(3-43 \mu \mathrm{m})$

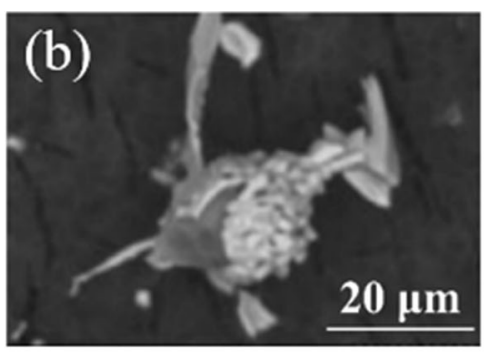

Cr-Si-Fe-Mn-O ( $8-45 \mu \mathrm{m})$

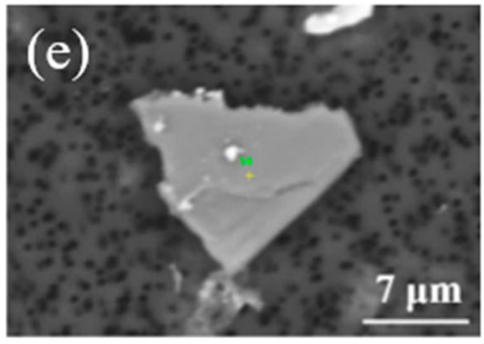

$\mathrm{Al}-\mathrm{O}(5-20 \mu \mathrm{m})$

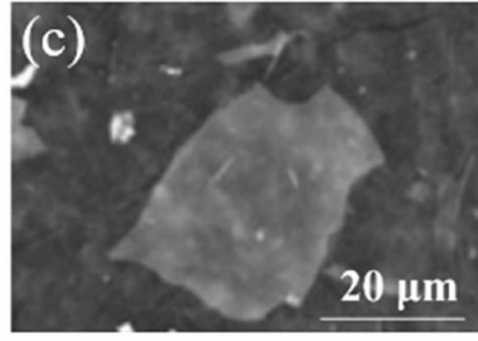

$\mathrm{Cr}-\mathrm{O}(6-30 \mu \mathrm{m})$

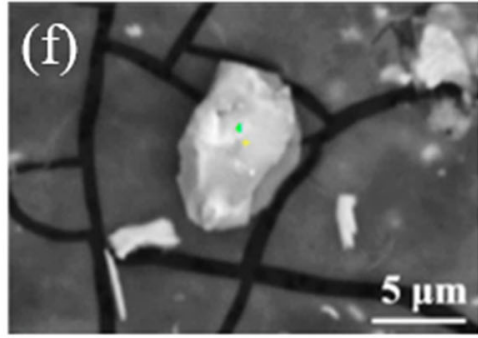

$\mathrm{Cr}-\mathrm{Mg}-\mathrm{Al}-\mathrm{O}(5-17 \mu \mathrm{m})$

Fig. 29-Classification of typical inclusions in LCFeCr alloys, $(a)$ through $(c)$ reprinted with permission from Ref. [17], and (d) through $(f)$ reprinted from Ref. [22], under the terms of the Creative Commons CC BY license.

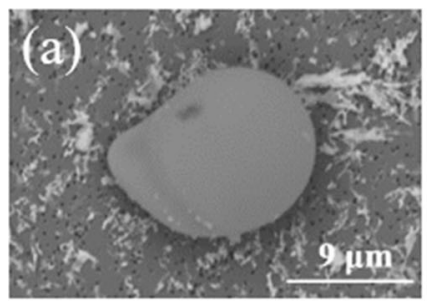

$\mathrm{Si}-\mathrm{O}(5-45 \mu \mathrm{m})$

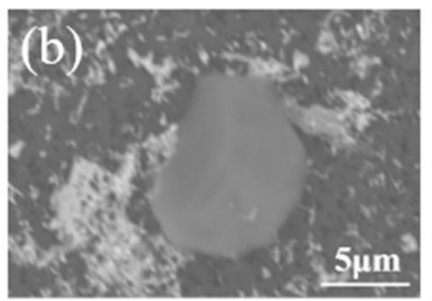

Si-Al-Mg-O (4-15 $\mu \mathrm{m})$

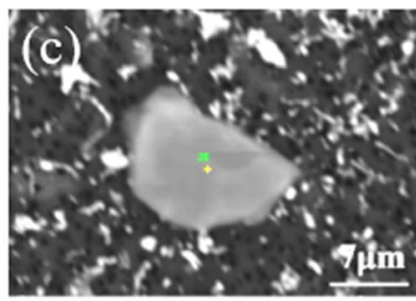

$\mathrm{Si}-\mathrm{Mg}-\mathrm{O}(9-16 \mu \mathrm{m})$

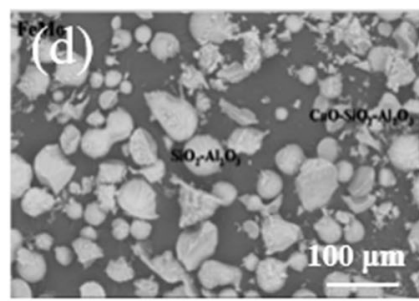

Si-Al-O $(10-50 \mu \mathrm{m})$

Fig. 30 - Classification of typical inclusions in FeMo alloys, (a) through (c) reprinted from Ref. [22], under the terms of the Creative Commons CC BY license and $(d)$ reprinted with permission from Ref. [21].

Except for homogeneous $\mathrm{Al}-\mathrm{Ti}-\mathrm{O}$ inclusions, heterogenous Al-Ti-O inclusions were also found, during nearly all process steps after a FeTi addition had been made, by several researchers. ${ }^{[62,111-114]}$ The formation process of heterogenous $\mathrm{Al}-\mathrm{Ti}-\mathrm{O}$ inclusions is shown schematically in Figure 25. Immediately after the FeTi alloy addition into the melt, the local concentration of Ti would be high, which provided a possibility of generation of $\mathrm{Al}_{2} \mathrm{TiO}_{5}$ or even $\mathrm{TiO}_{x}$ inclusions. Then, a region having a low [Ti]/[Al] ratio around the inclusion existed due to the generation of $\mathrm{TiO}_{x}$ inclusions and the diffusion of [Ti] in the melt. Thus, the generation of $\mathrm{Al}_{2} \mathrm{O}_{3}$ around the $\mathrm{Ti}-\mathrm{Al}-\mathrm{O}$ inclusion was promoted. Meanwhile, the transformation of $\mathrm{Ti}-\mathrm{Al}-\mathrm{O}$ inclusion to $\mathrm{Al}_{2} \mathrm{O}_{3}$ would take place from the surface to the inner part of the Ti-Al-O inclusion. As a result, a Ti-Al-O core surrounded by an $\mathrm{Al}_{2} \mathrm{O}_{3}$ layer was formed. Moreover, with longer times $\mathrm{TiO}_{x}$-rich inclusions were reduced by $\mathrm{Al}$ to again form $\mathrm{Al}_{2} \mathrm{O}_{3}$ inclusions, where their morphologies can change based on the $\mathrm{Ti} / \mathrm{Al}$ ratio. ${ }^{[114-117]}$
Aluminium is usually added before a FeTi alloy addition to reduce the formation of Ti-containing inclusions and to improve the $\mathrm{Ti}$ yield. Several researchers have investigated the inclusions in Al-killed Ti-bearing steels. ${ }^{[63,115,118,119]}$ The Ti/Al ratio has been found to be a key factor for controlling the inclusion types being formed. Usually, $\mathrm{Mg}-\mathrm{Al}-\mathrm{Ti}-\mathrm{O}$ complex inclusions were almost unavoidable in these steels due to the use of a MgO-based refractory. ${ }^{[120,121]}$ Thus, appropriate $\mathrm{Mg}, \mathrm{Al}$ and Ti contents in molten steel should be considered simultaneously to make the compositions of inclusions in a liquid $\mathrm{Al}_{2} \mathrm{O}_{3}-\mathrm{TiO}_{x}$ area, according to the Al-Ti-O stability diagram. ${ }^{[122-124]}$

Another possible way to obtain liquid inclusions in Al-killed Ti-bearing steel is through $\mathrm{Ca}$ treatment. ${ }^{[125-129]} \mathrm{Li}$ et al. ${ }^{[127]}$ reported that the evolution mechanism of the inclusions in Ti-bearing steels using a Ca treatment, as shown in Figure 26. They found that the initial $\mathrm{Ca}$ content had an important influence on the evolution of inclusions during titanium additions. The inclusion composition would be located in the liquid phase field after a FeTi addition, when the Ca content 
was lower than $5 \mathrm{ppm}$. When the Ca content was higher than 10 ppm, solid $\mathrm{CaTiO}_{3}$ and $\mathrm{CaAl}_{4} \mathrm{O}_{7}$ inclusions would be formed. This could lead to clogging of the submerged entry nozzle. Therefore, it is necessary to accurately control the $\mathrm{Ca}$ content in steel before a FeTi addition.

Except for the influence of the addition of FeTi on the steel cleanliness, the effect on the final steel properties is also important. A change of the mechanical properties in maraging steel due to FeTi additions was studied. The results showed that the addition of titanium caused the formation of small precipitates, which increased the strength and hardness. ${ }^{[130]}$ Similarly, Sinha et al ${ }^{[131]}$ and Vasudevan et al. ${ }^{[132]}$ reported that the number of small particles of $\mathrm{Ni}_{3} \mathrm{Ti}$ increased with the addition of FeTi alloys. However, a deeper discussion is out of the scope of the current work.

From the discussion above, it can be concluded that the most common inclusions in FeTi alloys are Al-Ti-O compounds as well as $\mathrm{TiO}_{x}, \mathrm{SiO}_{2}$ and $\mathrm{Al}_{2} \mathrm{O}_{3}$ inclusions. In this case, the $\mathrm{Al}_{2} \mathrm{O}_{3}$ and $\mathrm{Al}-\mathrm{Ti}-\mathrm{O}$ inclusions can directly be transferred into the molten steel during an alloy addition without having an obvious change and, therefore, have a harmful effect on the steel cleanliness. ${ }^{[110]}$ From this point of view, additional adjustments can be made if we clearly know the quality of FeTi alloys before their additions to steel. Also, the optimized compositions of liquid inclusions in Al-killed Ti-bearing steel can be obtained by accurately controlling the $\mathrm{Al}$ and $\mathrm{Ti}$ contents or by using a $\mathrm{Ca}$ treatment.

\section{5. $\mathrm{FeCr}$ alloys}

$\mathrm{HCFeCr}$ alloys are produced by carbothermic reduction of chromite ore in various technology routes. $\mathrm{LCFeCr}$ alloys can be produced in several ways. One way is to remove carbon from $\mathrm{HCFeCr}$ alloys via oxidation or by chromite $\left(\mathrm{FeO} \cdot \mathrm{Cr}_{2} \mathrm{O}_{3}\right)$ additions. Another way is to produce by oxidation of $\mathrm{FeSiCr}$ melt with chromite as well as reduction of chromite with silicon ( $\mathrm{FeSi}$ ) in the melt. In addition, it can be produced by aluminothermic reduction of raw materials. ${ }^{[9]}$

The typical inclusion types in $\mathrm{HCFeCr}$ alloys are shown in Figure 27. $\mathrm{MnCr}_{2} \mathrm{~S}_{3}$ inclusions containing some amounts of $\mathrm{O}$ and $\mathrm{Fe}, \mathrm{Cr}-\mathrm{C}-\mathrm{N}, \mathrm{Si}-\mathrm{Al}-\mathrm{Ca}-\mathrm{Mg}-\mathrm{O}$ complex oxides, and $\mathrm{Ca}-\mathrm{O}-\mathrm{P}$ inclusions were detected by $\mathrm{Bi}$ et $a .^{[17]}$ The melting points of $\mathrm{MnCr}_{2} \mathrm{~S}_{3}$, $\mathrm{Si}-\mathrm{Al}-\mathrm{Ca}-\mathrm{Mg}-\mathrm{O}$ and $\mathrm{Ca}-\mathrm{O}-\mathrm{P}$ inclusions are below the steelmaking temperature. The particle size distribution of the $\mathrm{Cr}-\mathrm{Mn}-\mathrm{S}-\mathrm{O}$ and $\mathrm{Ca}-\mathrm{O}-\mathrm{P}$ inclusions are presented in Figure 28(a). The number of $\mathrm{Cr}-\mathrm{Mn}-\mathrm{S}-\mathrm{O}$ inclusion per cubic millimeter is larger than for the $\mathrm{Ca}-\mathrm{O}-\mathrm{P}$ inclusions in the small size range $(<6 \mu \mathrm{m})$. However, the opposite trend is found for larger size inclusions (6 to $22 \mu \mathrm{m}$ ). It should be noticed that the total number of these inclusions per cubic millimeter is quite high (above $10,000 \mathrm{~mm}^{-3}$ ). The $\mathrm{Cr}-\mathrm{C}-\mathrm{N}$ inclusions, known as being high-temperature compounds, have melting ranges above the freezing point of steel. However, some physical and/or chemical changes may take place depending on the specific steelmaking conditions.

Sjökvist ${ }^{[5]}$ investigated the inclusion types in $\mathrm{HCFeCr}$ and $\mathrm{LPFeCr}$ alloys and found that the number of inclusions per unit area was lower in $\mathrm{HCFeCr}$ alloys compared to LPFeCr alloys. Specifically, a polygonal $(\mathrm{Cr}, \mathrm{Ti})(\mathrm{C}, \mathrm{N})$ was the most common inclusion type, having sizes up to $60 \mu \mathrm{m}$. The difference compared to $\mathrm{Bi}^{\text {' }}{ }^{[17]}$ results is that the average $\mathrm{Ti}$ content in $(\mathrm{Cr}$, $\mathrm{Ti})(\mathrm{C}, \mathrm{N})$ inclusions is about 47 mass pet, while that in $\mathrm{Cr}-\mathrm{C}-\mathrm{N}$ inclusions can be neglected. In addition, singular $\mathrm{Al}_{2} \mathrm{O}_{3}$ and $\mathrm{MnS}$ inclusions or $\mathrm{Al}_{2} \mathrm{O}_{3}$ presented as the core and surrounded by $\mathrm{MnS}$ were also found.

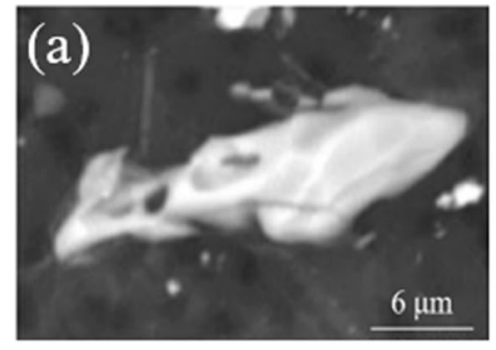

$\mathrm{Ti}-\mathrm{Nb}-\mathrm{S}-\mathrm{O}(1-14 \mu \mathrm{m})$

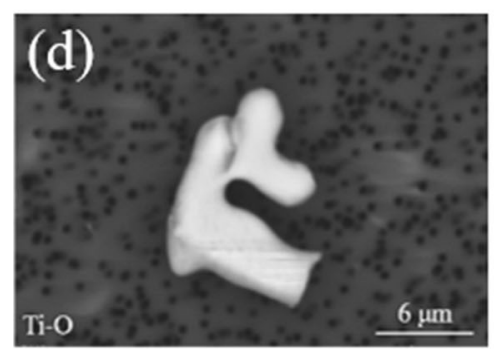

Ti-O $(5-69 \mu \mathrm{m})$

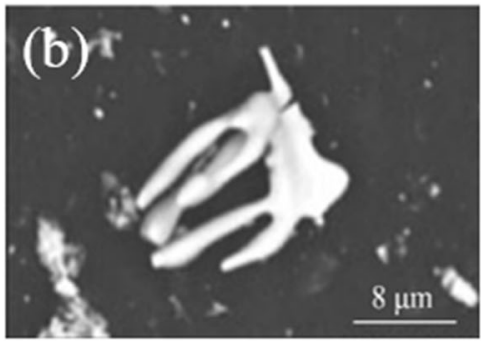

$\mathrm{Nb}-\mathrm{Ti}-\mathrm{O}(2-21 \mu \mathrm{m})$

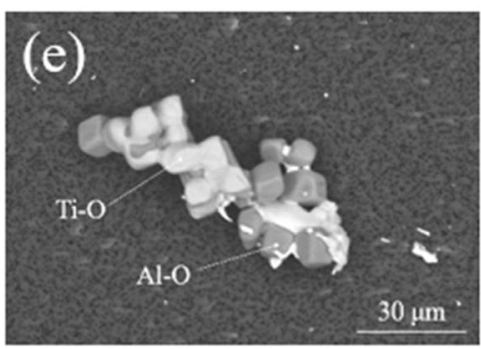

Ti-Al-O (11-118 $\mu \mathrm{m})$

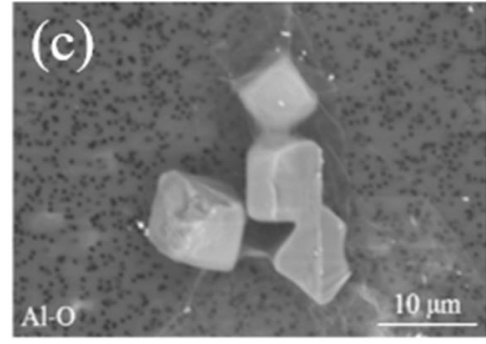

$\mathrm{Al}-\mathrm{O}(2-46 \mu \mathrm{m})$

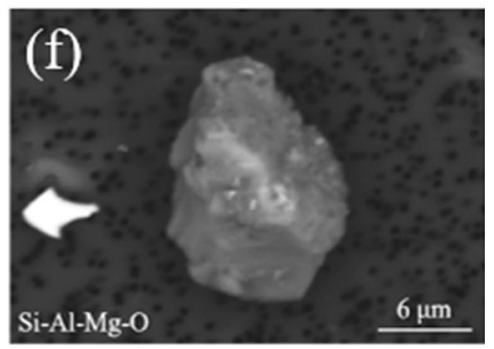

Si-Al-Mg-O (9-21 $\mu \mathrm{m})$

Fig. 31-Classification of typical inclusions in FeNb alloys, $(a)$ and $(b)$ reprinted with permission from Ref. [18] and $(c)$ through $(f)$ reprinted with permission from Ref. [76]. 


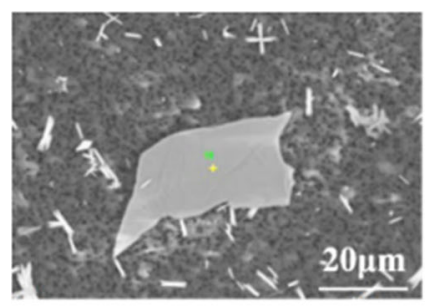

$\mathrm{Al}-\mathrm{O}(4-15 \mu \mathrm{m})$

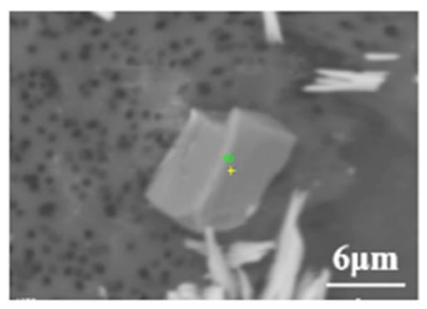

$\mathrm{Al}-\mathrm{Ca}-\mathrm{O}(3-12 \mu \mathrm{m})$

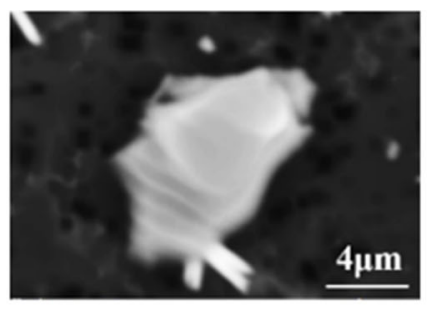

$\mathrm{Al}-\mathrm{Mg}-\mathrm{O}(3-13 \mu \mathrm{m})$

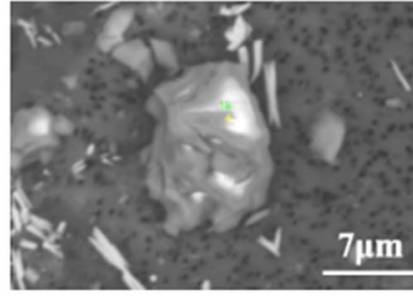

$\operatorname{Si}-\mathrm{O}(5-22 \mu \mathrm{m})$

Fig. 32-Classification of typical inclusions in FeV alloys. Reprinted from Ref. [22], under the terms of the Creative Commons CC BY license.

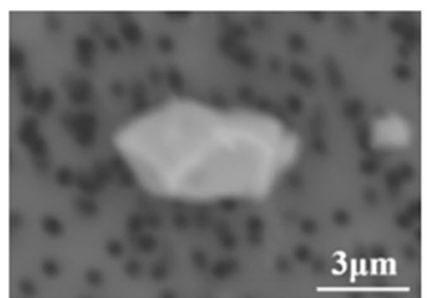

Al-O $(3-15 \mu \mathrm{m})$

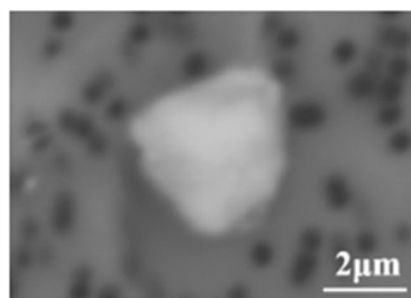

Si-Al-O $(3-20 \mu \mathrm{m})$

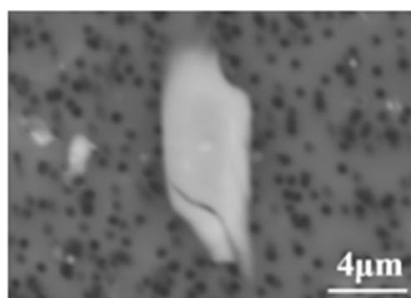

Si-O-(Al) $(4-28 \mu \mathrm{m})$

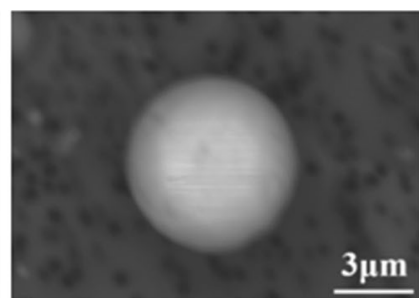

$\mathrm{Fe}-\mathrm{O}(5-13 \mu \mathrm{m})$

Fig. 33-Classification of inclusions in FeB alloys. Reprinted with permission from Ref. [22], under the terms of the Creative Commons CC BY license.

The findings of sulfides seem to disagree with the results of Metcalfe and Slatter ${ }^{[75]}$ and $\mathrm{Bi}$ et al., ${ }^{[17]}$ who found $\mathrm{MnCr}_{2} \mathrm{~S}_{3}$ and $\mathrm{Mn}_{2} \mathrm{CrS}_{3}$ inclusions instead of $\mathrm{MnS}$ inclusions. The difference might be the different $\mathrm{S}, \mathrm{Cr}$ and $\mathrm{Mn}$ contents in these $\mathrm{FeCr}$ alloys and the stabilities of different $\mathrm{Cr}$, Mn sulfide phases.

In another work of Sjökvist, ${ }^{[5]}$ they reported the effect of adding $\mathrm{HCFeCr}$ and $\mathrm{LPFeCr}$ alloys on the inclusion characteristics in steels. The inclusion content was at an almost equal level in the final steel samples after the addition of these two alloys to the steel during the ladle refining. The $\mathrm{MnS}$ and $(\mathrm{Cr}, \mathrm{Ti})(\mathrm{C}, \mathrm{N})$ inclusions from $\mathrm{FeCr}$ alloys were dissolved together with the alloys, and complex sulfide (Cr, Fe, Mn, Ti)S were formed during solidification. They concluded that the inclusions in the steel samples did not indicate an inheritance directly from the ferroalloy to the steel. However, one disadvantage of their work is that the $\mathrm{HCFeCr}$ alloy was added in the aluminium deoxidized melt, so it is hard to conclude whether the $\mathrm{Al}_{2} \mathrm{O}_{3}$ inclusions in the steel samples were present as a result of the $\mathrm{Al}$ deoxidation or if they were inherited from the $\mathrm{FeCr}$ alloys. Therefore, it is recommended that careful experiments should be done to verify the influence of $\mathrm{Al}_{2} \mathrm{O}_{3}$ inclusions from these $\mathrm{FeCr}$ alloys on steel cleanliness.

It should be noted that $\mathrm{HCFeCr}$ alloys are generally added in the EAF process and/or at a very early stage of the refining process such as during the desulfurization and dephosphorization steps. Therefore, the impurities in $\mathrm{HCFeCr}$ alloys might have enough time to be removed from the steel so that there will be no harmful effect on the steel cleanliness. This might also be the reason that few papers focused on this issue.
The typical inclusion types in $\mathrm{LCFeCr}$ alloys are shown in Figure 29. Inclusions in $\mathrm{LCFeCr}$ alloys were found to consist of $\mathrm{Si}-\mathrm{Cr}-\mathrm{Mn}-\mathrm{O}, \mathrm{Cr}-\mathrm{O}$, intermetallic particles and complex $\mathrm{Si}-\mathrm{Cr}-\mathrm{O}$ inclusions. ${ }^{[17]}$ Similar results showed that $\mathrm{Cr}$ silicates and $\mathrm{Cr}-\mathrm{Mn}$ silicates were present in $\mathrm{LCFeCr}$ alloys. ${ }^{[74]}$ The intermetallic phase will dissolve in the liquid steel, and the $\mathrm{Cr}-\mathrm{O}$ inclusions are assumed to have no large effect on the cleanliness of steel due to the reduction of chromium from the slag afterwards. ${ }^{[17]} \mathrm{In}$ addition, three $\mathrm{LCFeCr}$ alloys from different companies were compared using the EE method by Wang et al. ${ }^{[22]}$ The $\mathrm{Cr}-\mathrm{Mn}-\mathrm{O}, \mathrm{Cr}-\mathrm{Si}-\mathrm{M}-$ $\mathrm{n}-\mathrm{Al}-\mathrm{O}, \mathrm{Al}-\mathrm{O}$ and $\mathrm{Cr}-\mathrm{Mg}-\mathrm{Al}-\mathrm{O}$ inclusions were first reported in $\mathrm{LCFeCr}$ alloys. The particle size distribution of the $\mathrm{Cr}-\mathrm{Mn}-\mathrm{O}$ inclusions are presented in Figure 29(b). It can be seen that these $\mathrm{Cr}-\mathrm{Mn}-\mathrm{O}$ inclusions have a wide size range and number density in different $\mathrm{FeCr}$ alloys. From the perspective of melting point and floatation behaviour, they were listed as harmful inclusions. Their reactions with the deoxidizing elements or the existing inclusions in steel should be understood better. For example, $\mathrm{Cr}$ has a lower affinity to oxygen compared to other elements such as Al and Ti. Therefore, the Cr-based inclusions can easily be reduced and transformed into other types of inclusions. However, the effect of $\mathrm{Si}-\mathrm{Cr}-\mathrm{O}$ and $\mathrm{Cr}-\mathrm{Si}-\mathrm{Fe}-\mathrm{Mn}-\mathrm{O}$ and $\mathrm{Cr}-\mathrm{Mn}-\mathrm{O}$ inclusions in $\mathrm{LCFeCr}$ alloys on the steel quality is not clearly known. Compared to the $\mathrm{HCFeCr}$ alloys, $\mathrm{LCFeCr}$ alloys are added into the furnace during the very last stage of refining to fine-tune the chemical composition of specific steel grades. Thus, more attention should be paid to the purity of these alloys. In 
addition, further research is needed to study the actual behaviour of inclusions from $\mathrm{LCFeCr}$ alloys when they are added to liquid steel.

\section{Other alloys}

a. FeMo The mechanical properties of steels with FeMo additions have been studied by several researchers ${ }^{[133,134]}$. However, this aspect is not the focus of the current paper, so it will not be discussed here. For the quality of the FeMo alloys, Wang et al. ${ }^{[22]}$ also investigated the inclusions in FeMo alloys using the EE method. The typical inclusions in FeMo alloys are shown in Figure 30. It was found that $\mathrm{SiO}_{2}-\mathrm{MgO}$ and $\mathrm{SiO}_{2}-\mathrm{Al}_{2} \mathrm{O}_{3}-\mathrm{MgO}$ inclusions contained high $\mathrm{SiO}_{2}$ contents (> 70 mass pct), which had not been reported before. Moreover, the size range of $\mathrm{SiO}_{2}$ (up to $100 \mu \mathrm{m}$ ) inclusions on the metal surface after EE was significantly larger than that on the film filter.

Pande et al.$^{[21]}$ reported that acid-insoluble residues of FeMo alloys were spherical $\mathrm{SiO}_{2}$, irregular $\mathrm{Al}_{2} \mathrm{O}_{3}$, $\mathrm{SiO}_{2}-\mathrm{Al}_{2} \mathrm{O}_{3}$ and $\mathrm{CaO}-\mathrm{SiO}_{2}-\mathrm{Al}_{2} \mathrm{O}_{3}$ inclusions. These results showed a good agreement with Gasik's results. ${ }^{[73]}$ Overall, it can be concluded that pure $\mathrm{SiO}_{2}, \mathrm{Al}_{2} \mathrm{O}_{3}$ and high $\mathrm{SiO}_{2}$-containing inclusions are harmful inclusions in FeMo alloys. The high $\mathrm{SiO}_{2}$ content in these alloys is assumed to relate to their production processes, which should be optimized to decrease the presence of these inclusions. Considering the high melting point and high density, FeMo alloys are usually added during the early stages of ladle treatment. Thereby, harmful inclusions from the FeMo can have enough time to be transformed into less harmful inclusions and to float up and be separated from the steel. Very few studies have focused on this aspect, so research is still needed to verify this phenomenon.

b. $\mathrm{FeNb}$ The inclusions in $\mathrm{FeNb}$ alloys were also analyzed by $\mathrm{Bi}$ et $a l^{[18]}$ and Wang et al. ${ }^{[76]}$ and the typical inclusions in FeNb are shown in Figure 31. The results showed that the common inclusions are single and cluster $\mathrm{Al}-\mathrm{O}$, pure Ti-O and complex $\mathrm{Ti}-\mathrm{Al}-\mathrm{O}$ inclusions. Also, Bi et al. ${ }^{[18]}$ reported that 59 pet of the inclusions were $\mathrm{Nb}-\mathrm{Ti}-\mathrm{O}$ complex compounds and they can not be dissolved in steel melt, due to their high melting points $\left(2673 \mathrm{~K}, 2400{ }^{\circ} \mathrm{C}\right)$. Homogenous $\mathrm{Ti}-\mathrm{Nb}-\mathrm{S}-\mathrm{O}$ inclusions were also found. No matter they will dissolve or not after the addition to the steel, they are definitely deleterious to the steel cleanliness due to the presence of $\mathrm{S}$ and $\mathrm{O}$. Small amounts of irregular $\mathrm{Si}-\mathrm{Al}-\mathrm{Mg}-\mathrm{O}$ inclusions were also observed in $\mathrm{FeNb}$ alloys. The early dissolution of $\mathrm{FeNb}$ alloys in molten iron was studied by Wang et al. ${ }^{[76]}$ It was found that $\mathrm{Ti}-\mathrm{O}$ inclusions transformed into $\mathrm{Nb}-\mathrm{Ti}-\mathrm{O}$ inclusions, due to the high local $\mathrm{Nb}$ concentration when the alloy started to dissolve. Due to the presence of a large amount of harmful inclusions (such as Al-O and Ti-O) in $\mathrm{FeNb}$ alloys, a further study is needed to understand whether these inclusions will be present in the final steel product.
It was proposed that the addition of $\mathrm{FeNb}$ alloys may result in the formation of coarse inclusions in high strength low alloy (HSLA) cast products. Based on previous studies, there are two hypotheses about the origin of Nb-based coarse particles: (1) a formation due to segregation during solidification and (2) they originate from the ferroalloy additions during ladle metallurgy. Zhuo et al. ${ }^{[135,136]}$ investigated the segregation behaviour in HSLA steels. They proposed that the Ti-rich $(\mathrm{Ti}, \mathrm{Nb})(\mathrm{C}, \mathrm{N})$ transformed into an Nb-rich (Ti, $\mathrm{Nb})(\mathrm{C}, \mathrm{N})$ inclusion type when the cooling rate increased. Chen et al. ${ }^{[137]}$ also observed large particles of $(\mathrm{Ti}, \mathrm{Nb})(\mathrm{C}, \mathrm{N})$ in HSLA steels and they attributed the formation of these large particles to segregation. It has also been reported that $(\mathrm{Ti}, \mathrm{Nb})(\mathrm{C}, \mathrm{N})$ inclusions were associated with an incomplete dissolution of $\mathrm{FeNb}$ in molten steels. ${ }^{[138]}$ Commercial FeNb alloys have a melting point higher than the steelmaking temperature, so they tend to dissolve rather than melt when added to liquid steel. Thus, some $\mathrm{Nb}$-rich solid solutions remain undissolved and cause a negative influence on the mechanical properties of the final steel. ${ }^{[139-141]}$

Mendoza et al. ${ }^{[142]}$ concluded that the thermally stable phases in $\mathrm{FeNb}$ were embedded in the steel matrix during casting and that the large particles were the Laves phase of the $\mathrm{Fe}-\mathrm{Nb}$ system. Abraham et al. ${ }^{[139,140]}$ went further and suggested that the coarse particles observed in HSLA steels could be attributed to carbonitrides originating from $\mathrm{FeNb}$ alloys. Therefore, a special attention should be paid to the formation of niobium carbides and carbon-nitrides after the addition of $\mathrm{FeNb}$ alloys to steel. Thereafter, future work related to the dissolution of these particles when $\mathrm{FeNb}$ is added to steel should be studied.

c. $\mathrm{FeV}$ The typical inclusions found in $\mathrm{FeV}$ alloys using the EE method ${ }^{[22]}$ are shown in Figure 32 . The results showed that $\mathrm{VC}$ precipitations were the most common particles (not present here). These tended to be dissolved in the steelmaking process since they have lower melting temperatures than the steelmaking temperature. However, they might be precipitated again through interphase precipitation during cooling. Also, a plate $\mathrm{Al}_{2} \mathrm{O}_{3}$ was the main type of oxide inclusion, which accounted for about 76 pet of the total inclusions. Based on the investigations on the polished surface and the metal surface after extraction, the maximum length of $\mathrm{Al}_{2} \mathrm{O}_{3}$ inclusions can reach a value of $491 \mu \mathrm{m} .{ }^{[47]}$ Apart from $\mathrm{Al}_{2} \mathrm{O}_{3}$ inclusions, some high $\mathrm{Al}_{2} \mathrm{O}_{3}$-containing inclusions were observed. These might be closely related to the high $\mathrm{Al}$ content ( $\sim 3$ mass pct) in the FeV alloy. It can be concluded that the addition of $\mathrm{FeV}$ alloys inevitably increases the $\mathrm{Al}_{2} \mathrm{O}_{3}$ content in inclusions. This should be carefully considered when adding $\mathrm{FeV}$ alloys, especially during the final stage of the steelmaking process.

Vanadium affects the properties of steel by reducing the grain size and by contributing to dispersion hardening. Steel can be strengthened and toughened with grain refinement, precipitation and solid solution as vanadium mainly exist in the form of vanadium 


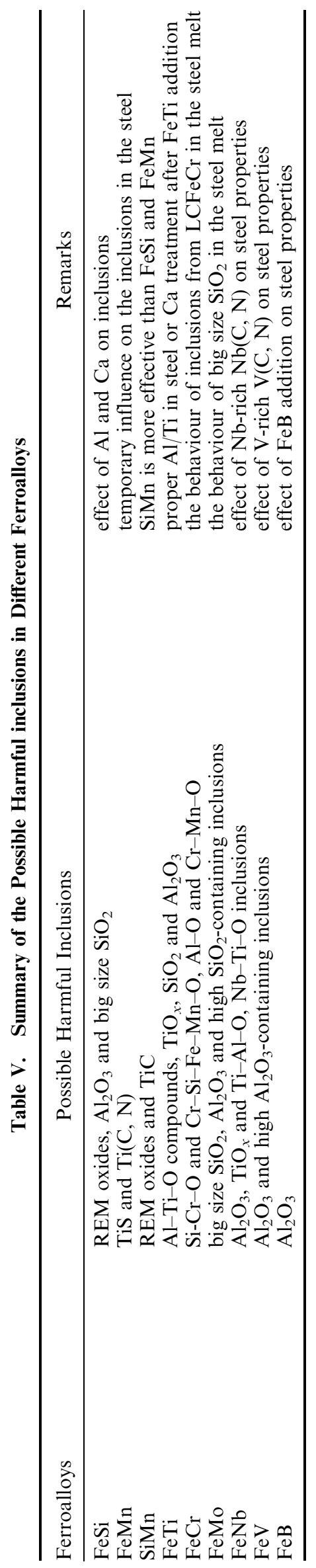


carbides, nitrides and/or carbonitrides and solid solutes. ${ }^{[143]}$ Except for the VC from the FeV alloys, the addition of $\mathrm{FeV}$ can easily lead to the formation of precipitates at a growing ferrite/austenite boundary. The VC precipitation can increase the hardness, ${ }^{[144,145]}$ hot ductility ${ }^{[146,147]}$ and hydrogen-embrittlement $(\mathrm{HE})$ resistance of steel. ${ }^{[148-151]}$

To conclude, the inclusions and precipitations along with the addition of $\mathrm{FeV}$ alloys are the two important points that steelmakers should consider in the future. Besides, from the point of production of $\mathrm{FeV}$ alloys, all the starting materials should be pure enough due to the absence of the process for selectively removing impurities in the alloys. ${ }^{[152]}$

d. $\mathrm{FeB}$ Inclusions in $\mathrm{FeB}$ alloys were firstly reported by Wang et al. ${ }^{[22]}$ where the typical inclusions are shown in Figure 33. The main type of inclusion is $\mathrm{Al}_{2} \mathrm{O}_{3}$, which is followed by almost pure $\mathrm{SiO}_{2}$ and $\mathrm{SiO}_{2}-\mathrm{Al}_{2} \mathrm{O}_{3}$ and $\mathrm{FeO}$ inclusions. $\mathrm{FeB}$ alloys are usually added during the final stage of well-deoxidized steel to get an optimized alloying result. From this point of view, inclusions originating from $\mathrm{FeB}$ alloys do not have enough time to be removed from the melt, so these alloys need to contain no harmful inclusions. The effect of microalloying of $\mathrm{B}$ on steel cleanliness was studied by Kim et al. ${ }^{[153]}$ They found that the amount of silicate inclusions in the boron-free steel was low, but the size can be as large as $200 \mu$ m which markedly degrade the mechanical characteristics of the steel. On the other hand, the boron-containing steel was characterized by boride inclusions having lengths being no more than 2 $\mu \mathrm{m}$. However, the mechanisms connected to the inclusion characteristics when adding $\mathrm{FeB}$ alloys to steel were not mentioned. Thus, detailed research is needed to understand the effect of inclusions from $\mathrm{FeB}$ alloys on steel cleanliness.

\section{Complex alloys}

Complex ferroalloys show greater advantages than single ones. Therefore, many researchers have paid more attention to these in recent years. ${ }^{[154,155]}$ This development is driven by the wish to improve the complex ferroalloys quality and to decrease the production cost. The combination of several elements usually decreases their activity (better extraction of elements) and melting temperature (formation of eutectics, etc.). ${ }^{[1]}$ For example, the melting temperatures of complex tungsten alloys are substantially decreased compared to that of ferrotungsten $(\mathrm{FeW})$. Furthermore, complex alloys lead to a more controlled inclusions formation when added to steels. Thus, more attention should be focused on these multicomponent alloys.

FeSiAl alloys represent promising and relatively universal reducing agents. They have been adopted industrially as reduction agents in a wide-range of killed and low-alloy steels. ${ }^{[155]}$ It was reported that the use of FeSiAl alloys greatly reduced the amount of oxide inclusions as well as their size in comparison to deoxidation using FeSi65 and Al. Moreover, the strength and plastic properties of steel were improved because oxysulfide inclusions were present in a globular form by the formation of low-melting phases. ${ }^{[156]}$
Zhan et al. ${ }^{[157]}$ studied the effect of AlMnCa and $\mathrm{SiCa}$ alloys on the deoxidization and modification of $\mathrm{Al}_{2} \mathrm{O}_{3}$ inclusions in the laboratory. They found that most of the $\mathrm{Al}_{2} \mathrm{O}_{3}$ inclusions were modified to small-sized spherical $\mathrm{CaO}-\mathrm{Al}_{2} \mathrm{O}_{3}$ based compounds after the addition of AlMnCa alloys to steel. For the production of a particular grade of Al-killed steel, AlMnCa alloys can be more effective to modify $\mathrm{Al}_{2} \mathrm{O}_{3}$ inclusions instead of using conventional $\mathrm{CaSi}$ alloys.

Akberdin et al. ${ }^{[158]}$ reported that new and complex ferroalloys like FeSiMnB, FeSiB can enhance the effect of boron on the steel properties, which have several advantages over binary $\mathrm{FeB}$ alloys. Introducing boron in the steel melt using FeSiMn alloys containing boron increases the boron yield from 48 to 77 pct on average in comparison to the use of $\mathrm{FeB}$ alloys. ${ }^{[3]}$ The increase of assimilation of $\mathrm{B}$ was likely attributed to the high concentration of deoxidizing elements, which decreased the oxidation of $\mathrm{B}$. Thus, the use of a complex boron-based alloy represents a very good alternative to add $\mathrm{B}$ to a steel melt.

Grigorovich et al. ${ }^{[159]}$ studied the deoxidizing capacity of $\mathrm{CaSiBa}$ master alloy in carbon steels. The results showed that the inclusion contamination of steel was significantly decreased as barium-containing inclusions were present in a liquid state. Golubtsov et al..$^{[160]}$ reported the same conclusions when studying wheel steels. Mukai and Han ${ }^{[161]}$ also reported that a CaSiBa treatment reduced the amount of $\mathrm{Al}_{2} \mathrm{O}_{3}$ inclusions in steel and resulted in small and globular inclusions in the final steel. The ability of the alloys to act as modifiers of inclusions increases in the following order: $\mathrm{BaSi}<\mathrm{CaSi}$ $<\mathrm{CaSiBa}$. The reason for this is that calcium has a stronger modification ability for inclusions than barium has. However, barium acts as a diluent of calcium and decreases the vapour pressure of calcium. Thus, it strengthens the modification ability of calcium. Moreover, in contrast to steel deoxidation with $\mathrm{CaSi}$, a replacement by $\mathrm{CaSiBa}$ allows for an increase of the toughness with 29 pct. ${ }^{[162]}$ Therefore, the use of complex barium-based modifiers can greatly improve steel cleanliness.

\section{SUMMARY OF INCLUSIONS IN DIFFERENT FERROALLOYS}

Based on the above discussions focusing on the inclusions in different ferroalloys and their effect on the steel cleanliness, a brief summary is presented in Table V. It shows the possible harmful inclusions in different ferroalloys and some suggestions for future studies. It shows that the behaviour of REM oxides, $\mathrm{Al}_{2} \mathrm{O}_{3}, \mathrm{TiO}_{x}, \mathrm{Ti}-\mathrm{Al}-\mathrm{O}, \mathrm{Cr}-\mathrm{Mn}-\mathrm{O}$ and big size $\mathrm{SiO}_{2}$ (up to $200 \mu \mathrm{m}$ ) inclusions from ferroalloys should be studied more in detail. Therefore, the behaviour of the existing inclusions from the ferroalloys in the steel and the newly inclusions related to the alloying process are two important factors to understand more in-depth. Instead of the behaviour of inclusions in the steel, the additions of $\mathrm{FeNb}, \mathrm{FeV}$ and $\mathrm{FeTi}$ alloys can cause some 
precipitations, which have important effects on the steel properties. This is another important research issue, which will not be discussed in-depth in this work.

\section{FUTURE DEMANDS AND PERSPECTIVES FOR FERROALLOYS}

The progress in the ferroalloy industry has closely followed the developments in the steel industry. With the development of the steel industry, some more strict demands on ferroalloy producers are suggested. It is expected that the ferroalloy suppliers will provide more detailed technical support of their products in the future. ${ }^{[163]}$ Some basic properties of ferroalloys (such as the chemical compositions, the melting point, the density, etc.) that meet the needs of steel producers should be known. ${ }^{[164]}$ Concerning alloying and trimming additions during the later process stages, typically ladles, some impurities (e.g., Al and Ti) can be critical, because they influence the non-metallic inclusions in steel and cause problems during casting. The ferroalloy containing many inclusions should be added to molten steel much earlier in the process to promote the separation and removal of inclusions from the steel melt. On the contrary, a very clean ferroalloy can be added later, which causes a little effect on the steel cleanliness and process time of steelmaking.

As steelmakers demand more versatile, efficient and reliable alloy additions, the ferroalloy industry is likely to change in response to the needs on the specific demand side as well as on the supply side. In addition to the improvements in the quality of ferroalloys, new and special ferroalloy products will increase significantly in the future. Moreover, new sustainable and environmental technologies will be developed in the ferroalloy industry with the progress in steel production technologies and the increase in the proportion of alloy steel applications.

Today, ferroalloy plants mainly produce standard alloys, which often lack the required characteristics for ladle treatment of high quality steels. Therefore, emerging steelmaking technologies call for the expansion of the existing ranges of ferroalloys. For example, one technology has been assimilated by Stepanov et al. ${ }^{[154]}$ for boron-containing pipe steels. They used a new combined ferroalloy (FeSiB) instead of a conventional expensive cored wire containing FB17 filler. The results showed that the new ferroalloy provided quite a high degree of boron assimilation, which is also in a good agreement with the results of Kim's study. ${ }^{[153]}$

On the other hand, there is the need to release more efficient complex ferroalloys, which allows for a reduction of the number of different types of ferroalloys used in the steel melt. They should be developed in the most favourable combination of components, contributing to a high degree of assimilation of useful elements, a rapid dissolution, and a uniform distribution in the melt. The development of new and improved ferroalloys needs to be carried out by also considering the melting kinetics and assimilation of elements present in the added ferroalloys. ${ }^{[165]}$ Recently, some complex ferroalloys of several systems ( $\mathrm{Fe}-\mathrm{Si}-\mathrm{Ba}-\mathrm{Ca}, \mathrm{Fe}-\mathrm{Si}-\mathrm{B}, \mathrm{Fe}-\mathrm{Si}-\mathrm{Al}-\mathrm{Nb}$, $\mathrm{Fe}-\mathrm{Si}-\mathrm{Ca}-\mathrm{Mg}, \mathrm{Fe}-\mathrm{Si}-\mathrm{V}-\mathrm{Ca}-\mathrm{Mn}, \mathrm{Fe}-\mathrm{Si}-\mathrm{Al})$ have been tested on an industrial scale. ${ }^{[166]}$ However, their physicochemical and thermophysical properties have not been studied to a large degree up to now.

Moreover, it is well known that small precipitates play a vital role in precipitation hardening grain refinement. These typical particles are usually endogenous, which are formed in-situ. Another principle is to prepare micro- or nano-particles ex situ and then add them before casting. In this case, a novel potential product is a ferroalloy which could carry nanoparticles. ${ }^{[3]}$ However, there is still plenty of research needed both by developers of steels and proper ferroalloy producers for these emerging applications.

For further developments of ferroalloy productions with a rational use of mineral resources, it is necessary to intensify the work in the following directions:

1. Assortment change of ferroalloys, development and enhancement of production of ferroalloys for micro-alloying and modification of steel to reach an improved steel quality;

2. Refined ferroalloy products will further be developed to improve the quality of ferroalloys by reducing the content of detrimental impurities (phosphorus, sulfur and other elements, inclusions);

3. Improve the existing technologies and develop new effective technologies of ferroalloy production with a higher performance characteristic as well as improved conditions of work and environmentally sustainable solutions;

4. Investigate the kinetics and mechanism of different ferroalloys with respect to the melting and dissolution in liquid steel;

5. Carefully investigate the effect of ferroalloy addition on steel cleanliness at the final stage of ladle treatment and to improve the technologies of late additions of ferroalloys in steel.

The competitive situation in the ferroalloy industry will provide the spur toward higher production efficiencies, lower costs and improved ferroalloy qualities. There are a variety of important factors concerning the sustainable production of ferroalloys such as energy efficiency, environmental issues, raw materials pre-treatment, economic aspects. Overall, the ferroalloy industry has numerous challenges ahead and it must undergo technological modernization and an in-depth transformation to develop more sustainable and flexible production routes.

\section{CONCLUSIONS}

This review examined a large number of published articles to improve the knowledge of inclusions in ferroalloys and how they influence steel quality. The characteristics of inclusions in FeSi, FeMn, SiMn, FeTi, $\mathrm{FeCr}$, FeMo, FeNb, FeV, FeB and other complex ferroalloys were summarized. The evolution and transformation of inclusions in the steel after the addition of some ferroalloys (FeSi, FeMn, FeTi) were also 
considered, but this kind of work is still not enough. It was found that some inclusions present in ferroalloys (e.g., $\mathrm{SiO}_{2}-\mathrm{MnO}, \mathrm{MnO}$ ) had very little influence on final steel cleanliness. On one hand, it was found that large size $\mathrm{SiO}_{2}$ inclusions $(\sim 200 \mu \mathrm{m})$ in FeSi and FeMo alloys and $\mathrm{Al}_{2} \mathrm{O}_{3}$ inclusions in $\mathrm{FeV}, \mathrm{FeNb}$ and FeTi alloys, so their production processes should be optimized to decrease the amount and size of these inclusions. On the other hand, some other inclusions [e.g., REM oxides, $\mathrm{Cr}-\mathrm{C}-\mathrm{N}, \mathrm{Cr}-\mathrm{Mn}-\mathrm{O}, \mathrm{Al}-\mathrm{Ti}-\mathrm{O}$, TiS and $\mathrm{Ti}(\mathrm{C}$, $\mathrm{N})$ ] with an unclear influence on steel quality have not been studied enough yet to make a clear judgement.

Some suggestions were made for future research work for each ferroalloy grade. Therefore, there are still many issues should be explored further to obtain a comprehensive information with respect to impurities (such as $\mathrm{O}, \mathrm{S}, \mathrm{P}$ as well as other trace elements and inclusions) in ferroalloys and how they behave when they are added to steel. From the perspective of future demands, the growth of the ferroalloy industry is directly linked to the growth and development of the steel industry. After clearly knowing the requirements concerning the steel cleanliness and the presence of possible harmful inclusions in different ferroalloys, the quality of ferroalloys can be improved by adjusting the current production processes. Any improvements in the quality of existing ferroalloys, as well as the development of new low-cost ferroalloys for early additions and high-cost alloys of high cleanliness for later additions, would be of great help to the development of the steel industry. Hence, it is inevitable that the ever-increasing momentum of steel and alloy technologies will bring higher quality, stronger steels and improved metals.

\section{ACKNOWLEDGMENTS}

Yong Wang acknowledges the financial support from the China Scholarship Council (CSC). Joo Hyun Park, acknowledges the LG Yonam Foundation, Korea, for his staying and collaborative research in $\mathrm{KTH}$ Royal Institute of Technology, Sweden, and also acknowledges the Korea Evaluation Institute of Industrial Technology (KEIT, with Grant Number 20013873), funded by the Ministry of Trade, Industry and Energy (MOTIE), Korea.

\section{CONFLICT OF INTEREST}

The authors declare no conflict of interest.

\section{FUNDING}

Open access funding provided by Royal Institute of Technology.

\section{OPEN ACCESS}

This article is licensed under a Creative Commons Attribution 4.0 International License, which permits use, sharing, adaptation, distribution and reproduction in any medium or format, as long as you give appropriate credit to the original author(s) and the source, provide a link to the Creative Commons licence, and indicate if changes were made. The images or other third party material in this article are included in the article's Creative Commons licence, unless indicated otherwise in a credit line to the material. If material is not included in the article's Creative Commons licence and your intended use is not permitted by statutory regulation or exceeds the permitted use, you will need to obtain permission directly from the copyright holder. To view a copy of this licence, visit http://creat ivecommons.org/licenses/by/4.0/.

\section{REFERENCES}

1. M. Gasik: Handbook of Ferroalloys: Theory and Technology, Butterworth-Heinemann, Amsterdam, 2013.

2. R.H. Eric: Treatise on Process Metallurgy, Elsevier, Amsterdam, 2014, pp. 477-532.

3. L.H. Jappa and S. Louhenkilpi: Proc. 13th Int. Ferroalloys Congr., Kazakhstan, 2013, pp. 1083-90.

4. T. Sjökvist, M. Goransson, P. Jönsson, and P. Cowx: Ironmak. Steelmak., 2003, vol. 30, pp. 73-80.

5. T. Sjökvist: Ph.D. Thesis, KTH Royal Institute of Technology, Stockholm, 2003.

6. O. Wijk and V. Brabie: ISIJ Int., 1996, vol. 36, pp. S132-35.

7. T. Sjökvist, P. Jönsson, and O. Grong: Metall. Mater. Trans. A, 2001, vol. 32A, pp. 1049-56.

8. T. Sjökvist and P. Jönsson: Proc. 57th Electr. Furn. Conf., Iron and Steel Society/AIME, USA, 1999, pp. 383-92.

9. B. Bhardwaj and F. Chrome: The Complete Book on Ferroalloys, NIIR Project Consultancy Services, Delhi, 2014.

10. S.E. Olsen, S. Olsen, M. Tangstad, and T. Lindstad: Production of Manganese Ferroalloys, Tapir Academic Press, Trondheim, 2007.

11. A.V. Zhdanov, V.I. Zhuchkov, V.Y. Dashevskii, and L.I. Leont'ev: Metallurgist, 2015, vol. 58, pp. 1064-70.

12. J. Lampman and A. Peters: Ferroalloys and Other Additives to Liquid Iron and Steel, ASTM International, West Conshohocken, 1981.

13. G. Saevarsdottir: Handbook of Ferroalloys, Elsevier, Oxford, 2013, pp. 139-75.

14. A.K. Kothari, R. Ranjan, R.S. Singh, G. Kumar, A. Kumar, and A. Agrawal: Ironmak. Steelmak., 2019, vol. 46, pp. 211-20.

15. G.A. Mashkovtsev and T.V. Bakanova: Theor. Pract. Conf. Int. Particip. Sch. Young Sci., Yekaterinburg, Russia, 2019, pp. 29-45.

16. E. But, R.M. Mustafin, and A.V. Pavlov: Theor. Pract. Conf. Int. Particip. Sch. Young Sci., Yekaterinburg, Russia, 2019, pp. 173-76.

17. Y. Bi, A. Karasev, and P.G. Jönsson: Ironmak. Steelmak., 2014, vol. 41, pp. 756-62.

18. Y. Bi, A. Karasev, and P.G. Jönsson: Steel Res. Int., 2014, vol. 85, pp. 659-69.

19. P.W. Han, S.J. Chu, P. Mei, and Y.F. Lin: J. Iron Steel Res. Int., 2014, vol. 21, pp. 23-27.

20. H.E. Kellner, A. Karasev, A. Memarpour, and P.G. Jönsson: Steel Res. Int., 2016, vol. 87, pp. 1461-68.

21. M.M. Pande, M. Guo, X. Guo, D. Geysen, S. Devisscher, B. Blanpain, and P. Wollants: Ironmak. Steelmak., 2010, vol. 37, pp. 502-11

22. Y. Wang, A. Karasev, and P.G. Jönsson: Metals, 2019, vol. 9, p. 687. 
23. Y. Lee: Ferroalloys: Production and Use in Steel-making, Elsevier, Amsterdam, 2001.

24. V. Dosaj, M. Kroupa, and R. Bittar: Kirk-Othmer Encyclopedia of Chemical Technology, Wiley-Interscience, New York, 2005.

25. A. Ducamp and O.S. Klevan: Innovative Si Alloys for Making of Electrical Steel, Elkem, Pittsburgh, 2018.

26. M. Tangstad: Ferrosilicon and Silicon Technology, Handbook of Ferroalloys, Elsevier, Oxford, 2013, pp. 179-220.

27. M. Tangstad: Manganese Ferroalloys Technology, Handbook of Ferroalloys, Elsevier, Oxford, 2013, pp. 221-66.

28. M.I. Gasik: Technology of Chromium and Its Ferroalloys, Handbook of Ferroalloys, Elsevier, Oxford, 2013, pp. 267-316.

29. D.R. Swinbourne, T. Richardson, and F. Cabalteja: Min. Process. Extr. Metall., 2016, vol. 125, pp. 45-55.

30. I. Manashev, I. Shatokhin, M.K. Ziatdinov, and V. Bigeev: Steel Transl., 2009, vol. 39, pp. 896-900.

31. N. Upadhyay, M.G. Pujar, T. Sakthivel, C. Mallika, K. Laha, and U.K. Mudali: Procedia Eng., 2014, vol. 86, pp. 606-14.

32. D. Ovchinnikov, O. Sofrygina, S.Y. Zhukova, I.Y. Pyshmintsev, and S. Bityukov: Steel Transl., 2011, vol. 41, pp. 356-60.

33. J.R. Davis: Alloying: Understanding the Basics, ASM International, Materials Park, 2001.

34. W. Trethewey and J. Jackman: Ferroalloys and Other Additives to Liquid Iron and Steel, ASTM International, West Conshohocken, 1981

35. O. Polyakov: Handbook of Ferroalloys, Elsevier, Oxford, 2013, pp. 459-69.

36. V.A. Vikhlevshchuk, A.S. Storozhenko, I.V. Kulikov, D.Y Levin, V.V. Zhilinskii, A.P. Obedkov, A.S. Pliskanovskii, O.V. Nosochenko, and S.G. Melnik: Metallurgist, 1987, vol. 31, pp. 200-03.

37. V. Zhuchkov, O. Zayakin, L. Leont'ev, and A. Sychev: Steel Transl., 2017, vol. 47, pp. 291-95.

38. Indian Minerals Yearbook 2019 (Part-II: Metals and Alloys), 58th Edition, Ferroalloys.

39. https://minerals.usgs.gov/minerals/pubs/commodity/myb/.

40. Y. Kwon, J. Choi, and S. Sridhar: Metall. Mater. Trans. B, 2011, vol. 42B, pp. 814-24.

41. M.M. Pande, M. Guo, S Devisscher, and B. Blanpain: Ironmak. Steelmak., 2012, vol. 39, pp. 519-29.

42. A. Das and T. Mukherjee: Ferro Alloy Industries in the Liberalised Economy, NML, Jamshedpur, 1996.

43. J.H. Park and Y.B. Kang: Metall. Mater. Trans. B, 2006, vol. 37B, pp. 791-97.

44. R.J.I. Bebbington: Proc. 7th Int. Femsoalloys Congr., Cape Town, South Africa, 1992, pp. 263-67.

45. K. Grigorovich, S. Shibaev, and I. Kostenko: Proc. 12th Int. Ferroalloys Congr., Helsinki, Finland, 2010, pp. 929-34.

46. R. Zakharov, S. Petrova, A. Zhdanov, and V. Zhuchkov: Russ. Metall., 2014, vol. 2014, pp. 8-13.

47. Y. Wang, A. Karasev, and P.G. Jönsson: Steel Res. Int., 2020, vol. 91 , p. 1900669

48. V. Thapliyal, A. Kumar, D. Robertson, and J. Smith: Ironmak. Steelmak., 2015, vol. 42, pp. 382-94.

49. S. Srivastava, S. Sinha, J. Bhambry, and S. Tudekar: Proc. Semin Probl. Prospects Ferro-Alloy Ind. India, Jamshedpur, India, 1983, pp. 299-308.

50. S.P.T. Piva: Ph.D. Thesis, Carnegie Mellon University, Pittsburgh, USA, 2018.

51. K. Mizuno, H. Todoroki, M. Noda, and T. Tohge: Iron Steelmak. (USA), 2001, vol. 28, pp. 93-101.

52. B.V. Patil and U.B. Pal: Metall. Trans. B, 1987, vol. 18, pp. 58389.

53. V. Thapliyal, A. Kumar, D. Robertson, and J. Smith: ISIJ Int., 2015, vol. 55, pp. 190-99.

54. Y.P. Vorob'ev: Steel Transl., 2008, vol. 38, pp. 69-76.

55. F. Oeters, L. Zhang, C. Hauler, and J. Leitner: Steel Res., 2000, vol. 71 , pp. $381-90$

56. R. Yilmaz, A. Gökçe, and H. Kapdibaş: Adv. Mater. Res., 2007, vol. 23, pp. 71-74.

57. O. Nokhrina, I. Rozhikhina, V. Dmitrienko, M. Golodova, and Y.A. Osipova: Steel Transl., 2014, vol. 44, pp. 715-18.

58. S. Abdelaziz, G. Megahed, I. El-Mahallawi, and H. Ahmed: Ironmak. Steelmak., 2009, vol. 36, pp. 432-41.
59. C.H. Chang, I.H. Jung, S.C. Park, H.S. Kim, and H.G. Lee: Ironmak. Steelmak., 2005, vol. 32, pp. 251-57.

60. C. Feng, C.F. Yang, S. Hang, Y.Q. Zhang, and X. Zhou: J. Iron Steel Res. Int., 2009, vol. 16, pp. 69-74.

61. M.M. Pande, M.X. Guo, and B. Blanpain: ISIJ Int., 2013, vol. 53, pp. 629-38.

62. M.K. Sun, I.H. Jung, and H.G. Lee: Met. Mater. Int., 2008, vol. 14, pp. 791-98.

63. M.A. Van Ende, M. Guo, R. Dekkers, M. Burty, J. Van Dyck, P.T. Jones, B. Blanpain, and P. Wollants: ISIJ Int., 2009, vol. 49, pp. 1133-40.

64. Y. Liu, X. Wang, and S. Peng: Proc. Int. Ferroalloys Exch. Conf. Beijing, Beijing, China, 2006, pp. 124-32.

65. G. Franklin, G. Rule, and R. Widdowson: Proc. Vth Int. Congr. X-Ray Opt. Microanal., Tübingen, Germany, 1969, pp. 474-80.

66. V. Povolotskii, T. Komissarova, and V. Minaev: Izv. Vyssh. Uchebn Zaved Chern Metall., 1987, vol. 8, pp. 31-35.

67. Q.C. Horn, R.W. Heckel, and C.L. Nassaralla: Metall. Mater. Trans. B, 1998, vol. 29B, pp. 325-29.

68. J.Q. Du, H.J. Zhang, L.F. Zhang, and Y. Ren: Proc. 10th China Iron Steel Annu. Conf. (in Chinese), Shanghai, China, 2015.

69. M. Li, S. Li, Y. Ren, W. Yang, and L. Zhang: Ironmak. Steelmak., 2020, vol. 47, pp. 6-12.

70. W. Li, Y. Ren, and L. Zhang: Ironmak. Steelmak., 2020, vol. 47, pp. $40-46$.

71. V. Sharapova: Steel Transl., 2010, vol. 40, pp. 1092-94.

72. P. Kaushik, H. Pielet, and H. Yin: Ironmak. Steelmak., 2009, vol. 36 , pp. 561-71.

73. M. Gasik, A. Panchenko, and A. Salnikov: Metall. Min. Ind., 2011, vol. 3, pp. 1-9.

74. W. Tiekink, A. Overbosch, P. Broersen, R. Kooter, M. Rijnders, and L. Alders: Stahl Eisen., 2013, vol. 133, pp. 59-64.

75. B. Metcalfe and D. Slatter: Ironmak. Steelmak., 1978, vol. 5, pp. 103-06.

76. Y. Wang, A. Karasev, J.H. Park, and P.G. Jönsson: ISIJ Int., 2021, vol. 61, pp. 209-18.

77. J. Xu, K. Wang, Y. Wang, Z. Qu, X. Tu, and X. Meng: Ironmak. Steelmak., 2020, pp. 1-6.

78. S.P. Piva and P.C. Pistorius: Metall. Mater. Trans. B, 2021, vol. 52B, pp. 6-16.

79. Y.B. Kang and H.G. Lee: ISIJ Int., 2004, vol. 44, pp. 1006-15.

80. C. Bertrand, J. Molinero, S. Landa, R. Elvira, M. Wild, G. Barthold, P. Valentin, and H. Schifferl: Ironmak. Steelmak., 2003, vol. 30, pp. 165-69.

81. H. Ohta and H. Suito: Metall. Mater. Trans. B, 1996, vol. 27B, pp. 263-70.

82. G. Parker: Encyclopedia of Materials: Science and Technology, Elsevier, Amsterdam, 2001, pp. 3703-07.

83. C. Dumay, C. Chatillon, and M. Allibert: J. Chim. Phys., 1997, vol. 94, pp. 971-77.

84. C. Dumay and M. Allibert: Scand. J. Metall., 2002, vol. 31, pp. $107-14$

85. S. Tome-Torquemada, B. Glaser, K. Hildal, and S.C. Du: Metall. Mater. Trans. B, 2017, vol. 48B, pp. 3251-58.

86. L.F. Zhang: Steel Res. Int., 2006, vol. 77, pp. 158-69.

87. T. Sjöqvist, P. Jönsson, and Ö. Grong: Metall. Mater. Trans. A, 2001, vol. 32A, pp. 1049-56.

88. F. Li, H. Li, S. Zheng, J. You, K. Han, and Q. Zhai: Materials, 2017, vol. 10, p. 1206.

89. M. Wang, Y.P. Bao, and L.D. Xing: ISIJ Int., 2018, vol. 58, pp. 886-91.

90. M. Fernandes, J.C. Pires, N. Cheung, and A Garcia: Mater. Charact., 2003, vol. 51, pp. 301-08.

91. P. Misra, V. Chevrier, S. Sridhar, and A. Cramb: Metall. Mater. Trans. B, 2000, vol. 31B, pp. 1135-39.

92. S.K. Choudhary and S. Chandra: ISIJ Int., 2007, vol. 47, pp. 190-92.

93. P. Yan, M. Guo, and B. Blanpain: Metall. Mater. Trans. B, 2014 , vol. 45B, pp. 903-13.

94. K. Wang, M. Jiang, X. Wang, Y. Wang, H. Zhao, and Z. Cao: Metall. Mater. Trans. B, 2015, vol. 46B, pp. 2198-2207.

95. C. Shi and J.H. Park: Metall. Mater. Trans. B, 2019, vol. 50B, pp. 1139-47.

96. V. Thapliyal: Ph.D. Thesis, Missouri University of Science and Technology, Rolla, USA, 2015. 
97. Y. Zhang, Y. Ren, and L. Zhang: Metall. Res. Technol., 2017, vol. 114 , p. 308.

98. J.S. Park and J.H. Park: Metall. Mater. Trans. B, 2014, vol. 45B, pp. 953-60.

99. L.K. Singhal and S. Patra: Adv. Mater. Res., vol. 794, pp. 124-31.

100. S. Yang, J. Li, L. Zhang, K. Peaslee, and Z. Wang: Metall. Min. Ind., 2010, vol. 2, pp. 87-92.

101. X. Cai, Y. Bao, L. Lin, and C. Gu: Steel. Res. Int., 2016, vol. 87 , pp. 1168-78.

102. C. Mapelli and P. Nolli: ISIJ Int., 2003, vol. 43, pp. 1191-99.

103. Y.B. Kang, H.S. Kim, J. Zhang, and H.G. Lee: J. Phys. Chem. Solids, 2005, vol. 66, pp. 219-25.

104. X. Yin, Y. Sun, Y. Yang, X. Deng, M. Barati, and A. McLean: Ironmak. Steelmak., 2017, vol. 44, pp. 152-58.

105. H. Berg, H. Laux, and S. Johansen: Ironmak. Steelmak., 1999, vol. 26, pp. 127-39

106. N. Kojola, S. Ekerot, M. Andersson, and P.G. Jönsson: Ironmak. Steelmak., 2011, vol. 38, pp. 1-11.

107. A. Memarpour, V. Brabie, and P. Jönsson: Ironmak. Steelmak., 2011, vol. 38, pp. 229-39.

108. H.S. Kim, H.G. Lee, and K.S. Oh: ISIJ Int., 2002, vol. 42, pp. 1404-11.

109. Y.B. Kang and H.G. Lee: ISIJ Int., 2005, vol. 45, pp. 1552-60.

110. P. Dorrer, S.K. Michelic, C. Bernhard, A. Penz, and R. Rössler: Steel Res. Int., 2019, vol. 2019, p. 1800635.

111. W. Yang, S. Li, Y. Li, X. Wang, L. Zhang, X. Liu, and Q. Shan: Materials Processing Fundamentals, Springer, Cham, 2013,pp.3-16.

112. X. Deng, C. Ji, Y. Cui, Z. Tian, X. Yin, X. Shao, Y. Yang, and A McLean: Ironmak. Steelmak., 2017, vol. 44, pp. 739-49.

113. W.C. Doo, D.Y. Kim, S.C. Kang, and K.W. Yi: Met. Mater. Int., 2007, vol. 13, pp. 249-55.

114. M. Wang, Y.P. Bao, H. Cui, H.J. Wu, and W.S. Wu: ISIJ Int., 2010, vol. 50, pp. 1606-11.

115. H. Matsuura, C. Wang, G. Wen, and S. Sridhar: ISIJ Int., 2007, vol. 47 , pp. $1265-74$

116. C. Wang, N.T. Nuhfer, and S. Sridhar: Metall. Mater. Trans. B, 2009, vol. 40B, pp. 1005-21.

117. C. Wang, N. Verma, Y. Kwon, W Tiekink, N. Kikuchi, and S. Sridhar: ISIJ Int., 2011, vol. 51, pp. 375-81.

118. I.H. Jung, G. Eriksson, P. Wu, and A. Pelton: ISIJ Int., 2009, vol. 49 , pp. $1290-97$.

119. C. Wang, N. Verma, Y. Kwon, W. Tiekink, N. Kikuchi, and S. Sridhar: ISIJ Int., 2011, vol. 51, pp. 1838-45.

120. T. Zhang, C. Liu, and M. Jiang: Metall. Mater. Trans. B, 2016, vol. 47B, pp. 2253-62.

121. Y. Ren, L. Zhang, W. Yang, and H. Duan: Metall. Mater. Trans. $B, 2014$, vol. 45B, pp. 2057-71.

122. J. Li, G. Cheng, Q. Ruan, J. Pan, and X. Chen: ISIJ Int., 2018, vol. 58, pp. 2280-87.

123. Y.B. Kang and J.H. Lee: ISIJ Int., 2017, vol. 57, pp. 1665-67.

124. C. Wang, N.T. Nuhfer, and S. Sridhar: Metall. Mater. Trans. B, 2009, vol. 40B, pp. 1022-34

125. C.W. Seo, S.H. Kim, S.K. Jo, M.O. Suk, and S.M. Byun: Metall. Mater. Trans. B, 2010, vol. 41B, pp. 790-97.

126. D. Kruger and A. Garbers-Craig: Metall. Mater. Trans. B, 2017, vol. 48B, pp. 1514-32.

127. J. Li, G. Cheng, Q. Ruan, J. Pan, and X. Chen: Metall. Mater. Trans. B, 2018, vol. 49B, pp. 2357-69.

128. J. Li, G. Cheng, Q. Ruan, J. Pan, and X. Chen: Ironmak. Steelmak., 2020, vol. 47, pp. 31-39.

129. J. Li, G. Cheng, Q. Ruan, J. Li, J. Pan, and X. Chen: ISIJ Int., 2018, vol. 58, pp. 1042-51.

130. S.R.E. Hosseini and H. Arabi: ISIJ Int., 2012, vol. 52, pp. 147-50.

131. P.P. Sinha, K.T. Tharian, K. Sreekumar, K.V. Nagarajan, and D.S. Sarma: Mater. Sci. Technol., 1998, vol. 14, pp. 1-9.

132. V.K. Vasudevan, S.J. Kim, and C.M. Wayman: Metall. Trans. A, 1990, vol. 21, pp. 2655-68.

133. N. Chawla and X. Deng: Mater. Sci. Eng. A, 2005, vol. 390 pp. $98-112$.

134. W. García, S. Sainz, and F. Castro: Proc. Eur. Congr. Exhib. Powder Metall., Shrewsbury, UK, 2010, pp. 1-8.
135. X. Zhuo, X. Wang, W. Wang, and H.G. Lee: J. Univ. Sci. Technol. B, 2007, vol. 14, pp. 112-17.

136. X.J. Zhuo, D.H. Woo, X.H. Wang, and H.G. Lee: J. Iron Steel Res Int., 2008, vol. 15, pp. 70-77.

137. Z. Chen, M.H. Loretto, and R.C. Cochrane: Mater. Sci. Technol., 1987, vol. 3, pp. 836-44

138. S. Abraham, R. Klein, R. Bodnar, and O. Dremailova: Mater. Sci. Technol. Conf. Exhib., Ohio, USA, 2006, vol. 2, pp. 89-104.

139. S. Abraham, R. Klein, R. Bodnar, and O. Dremailova: Mater. Sci. Technol. Conf. Exhib., Ohio, USA, 2006, vol. 2, pp. 109-20.

140. P. Gong, E.J. Palmiere, and W.M. Rainforth: Acta Mater., 2015, vol. 97, pp. 392-403

141. S. Yuan and G.J.M.L. Liang: Mater. Lett., 2009, vol. 63, pp. 2324-26.

142. R. Mendoza, J. Huante, M. Alanis, C. Gonzalez-Rivera, and J.A. Juarez-Islas: Ironmak. Steelmak., 1999, vol. 26, pp. 205-09.

143. P. Tian, Z. Zhong, R. Bai, X. Zhang, and H. Gao: Proc. Int. Conf. Comput. Inf. Syst. Ind. Appl., Bangkok, Thailand, 2015, pp. 861-64.

144. G. Miyamoto, R. Hori, B. Poorganji, and T. Furuhara: ISIJ Int., 2011, vol. 51, pp. 1733-39.

145. V. Ollilainen, W. Kasprzak, and L. Holappa: J. Mater. Process. Technol., 2003, vol. 134, pp. 405-12.

146. A. Salas-Reyes, I. Mejía, A. Bedolla-Jacuinde, A. Boulaajaj, J. Calvo, and J.M. Cabrera: Mater. Sci. Eng. A, 2014, vol. 611, pp. $77-89$.

147. F. Reyes-Calderón, I. Mejía, and J.M. Cabrera: Mater. Sci. Eng. $A, 2013$, vol. 562 , pp. 46-52.

148. J. Lee, T. Lee, Y.J. Kwon, D.J. Mun, J.Y. Yoo, and C.S. Lee: Met. Mater. Int., 2016, vol. 22, pp. 364-72.

149. X.F. Yang, H. Yu, C.H. Song, and L.L. Li: Metals, 2019, vol. 9 , p. 741.

150. L. Cho, E.J. Seo, D.H. Sulistiyo, K.R. Jo, S.W. Kim, J.K. Oh, Y.R. Cho, and BC De Cooman: Mater. Sci. Eng. A, 2018, vol. 735 , pp. $448-55$.

151. X.B. Cheng, X.Y. Cheng, C.W. Jiang, X.Y. Zhang, and Q.F. Wen: Mater. Lett., 2018, vol. 213, pp. 118-21.

152. E.F. Baroch: Kirk-Othmer Encyclopedia of Chemical Technology, Wiley, New York, 2000, pp. 1-18.

153. A. Kim, O. Zayakin, A. Akberdin, and Y.V. Kontsevoi: Russ. Metall., 2010, vol. 2010, pp. 1148-50.

154. A.I. Stepanov, A.A. Babenko, A.V. Sychev, V.I. Zhuchkov, A.V. Murzin, L.E. Dresvyankina, and M.V. Ushakov: Metallurgist, 2014, vol. 58, pp. 588-90.

155. M.Z. Tolymbekov, A. Akhmetov, S. Baisanov, E. Ogurtsov, and D. Zhiembaeva: Steel Transl., 2009, vol. 39, pp. 416-19.

156. A. Mekhtiyev, A. Akhmetov, V. Yudakova, and F. Bulatbayev: Metalurgija, 2016, vol. 55, pp. 47-50.

157. D.P. Zhan, H.S. Zhang, and Z.H. Jiang: J. Iron Steel Res. Int., 2008, vol. 15, pp. 15-18.

158. A. Akberdin, Y.S. Yusfin, and T. Toymankulov: Steel Transl., 2014, vol. 44, pp. 21-23.

159. K. Grigorovich, K.Y. Demin, A. Arsenkin, and A. Garber: Russ. Metall., 2011, vol. 2011, pp. 912-20.

160. V. Golubtsov, K.Y. Demin, Y.S. Demin, L. Shub, and I. Ryabchikov: Steel Transl., 2009, vol. 39, pp. 1078-83.

161. K. Mukai and Q.Y. Han: ISIJ Int., 1999, vol. 39, pp. 625-36.

162. I. Ryabchikov and V. Kovalev: J. Chem. Technol. Metall., 2016, vol. 51, pp. 465-72.

163. R. Dippenaar: Proc. 10th Int. Ferroalloys Congr., Cape Town, South Africa, 2004, pp. 741-56.

164. V. Zhuchkov, N. Andreev, O. Zayakin, Y.I. Ostrovskii, and V. Afanas'ev: Steel Transl., 2013, vol. 43, pp. 306-08.

165. D.N. Togobitskaya, V.P. Piptyuk, A.F. Petrov, S.V. Grekov, and A.S. Mirgorodskaya: Metallurgist, 2019, vol. 62, pp. 1115-22.

166. V.I. Zhuchkov and O.V. Zayakin: Theor. Pract. Conf. Int. Particip. Sch. Young Sci., Yekaterinburg, Russia, 2019, pp. 138-44.

Publisher's Note Springer Nature remains neutral with regard to jurisdictional claims in published maps and institutional affiliations. 